\title{
Ânforas Do Acampamento / Sítio Romano De Alto Dos Cacos (Almeirim, Portugal)
}

\author{
Rui Roberto de Almeida \\ UNIARQ - Centro de Arqueologia da Universidade de Lisboa. Faculdade de Letras. Universidade de Lisboa \\ JoÃo Pimenta \\ Centro de Estudos Arqueológicos de Vila Franca de Xira (CEAX) \\ UNIARQ - Centro de Arqueologia da Universidade de Lisboa. Faculdade de Letras. Universidade de Lisboa
}

Recibido: 07/02/2018

Revisado: 28/05/2018
Aceptado: $31 / 05 / 2018$

Publicado: 29/06/2018
RESUMO

O sítio de Alto dos Cacos (Almeirim, Portugal), situa-se nas imediações da Vala de Alpiarça e do Rio Tejo, ocupando uma posição dominante sobre a zona envolvente. Trata-se de um vasto sítio arqueológico detectado no início dos anos 80 do século passado, na sequência de profundas e extensas destruições fruto de trabalhos agrícolas, mas que depois caiu no esquecimento durante mais de trinta anos.

$\mathrm{O}$ inicio da sua investigação em momentos mais recentes e os dados aferidos a partir de estudos parcelares, entretanto publicados, de diversos materiais arqueológicos aí recolhidos que se elevam a várias centenas de artefactos dos mais variados tipos, permitiram reconhecer a relevância do sítio e identificá-lo como um acampamento militar romano de época tardo-republicana.

O presente trabalho pretende dar a conhecer de forma detalhada o seu numeroso e importante conjunto de ânforas. À semelhança de outros conjuntos actualmente conhecidos no quadro de conquista do ocidente hispânico, o que agora se estuda apresenta um padrão dominado pelas primeiras produções próprias da província Ulterior, destacando pela sua raridade a existência de algumas ânforas com tituli picti.

\section{Palabras Clave}

Ânforas; Acampamento militar; Baixo Vale do Tejo; Tardo-Republicano; Comércio Hispania.
ABSTRACT

The Alto dos Cacos site (Almeirim, Portugal) is located in the vicinity of Vala de Alpiarça and Tagus River, occupying a dominant position on the surrounding area. It is a vast archaeological site that was detected in the early 80 s of the 20th century, due to a deep and extensive destruction caused by heavy agricultural works. After it, was kept forgotten for more than thirty years.

Only recently has started its research and the data that has been inferred from the study and publishing of several small assamblages of the collection, which consist in several hundreds of the most diverse artifacts, allowed to recognize the relevance of the site and identifying it as a Roman Late-Republic military camp.

The present study intends to present a detailed study of its important set of amphorae. Like other amphorae assemblages currently known for the western Hispania, this set presents a pattern dominated by the first original amphorae productions from the province of Hispania Ulterior, emphasizing for its rarity the existence of some amphorae with tituli picti.

\section{KEY WORDS}

Amphorae; Military site; Low Tagus Valley; Late Republican; Commerce in Hispania 


\section{INTRODUÇÃO E ENQUADRAMENTO}

A estação arqueológica de Alto do Cacos enquadra-se administrativamente no actual Concelho de Almeirim, distrito de Santarém (Portugal), situando-se a cerca de $1,5 \mathrm{~km}$ a Este do centro histórico da cidade de Almeirim. Implanta-se sobre uma área arenosa que constitui um pequeno cabeço de uma antiga duna consolidada sobre a margem esquerda do paúl de Vale de Peixes, com uma altitude média de $14 \mathrm{~m}$.

Situado nas imediações da Vala de Alpiarça e do Rio Tejo, as características topográficas do sítio favorecem a implantação humana, possuindo uma plataforma relativamente plana de orientação NE-SE, dispondo de excelente visibilidade e apresentando, apesar da sua escassa altura, uma posição francamente dominante sobre a zona envolvente, constituída por baixas aluvionares alagadiças (ver Fig.1).

A sua localização permite um contacto visual directo com espaços de ocupação romana e pré-romana da região: mesmo em frente, do outro lado do Rio Tejo, situa-se em posição de sobranceria a cidade de Santarém, antiga urbe de Scallabis (Fig.2); alguns quilómetros mais à direita mas em perfeito contacto visual ergue-se o povoado fortificado dos Chões de Alpompé; na mesma margem, a cerca de $2 \mathrm{~km}$ situa-se o antigo povoado do Cabeço da Bruxa e a $3 \mathrm{~km}$ o amplo planalto fortificado de Alto do Castelo, ambos em Alpiarça (ver Fig.1).

A descoberta da existência e relevância do sítio de Alto dos Cacos foi detectada por Eurico Henriques no início dos anos oitenta do século passado, na sequência da realização de uma grande acção de trabalhos agrícolas pesados que implicaram profundas e extensas destruições (Henriques, 1982) (Ver Fig.2). Apesar de diversas diligências então efectuadas, o sítio não foi alvo de quaisquer trabalhos arqueológicos, caindo praticamente no esquecimento até aos dias de hoje.

O presente trabalho tem como objectivo apresentar o expressivo conjunto de ânforas aí recuperado, enquadrando-o nas dinâmicas comerciais e de abastecimento do Baixo Vale do Tejo. Paralelamente, e não menos importante, constitui, ainda, mais um estudo parcelar deste importante sítio e insere-se num projecto de estudo mais amplo e estruturado em torno desta singular estação arqueológica e do avultado conjunto de materiais arqueológicos aí recolhidos, que tem como principal objectivo a publicação e divulgação sistemática da diversificada colecção que desde essa data se encontra depositada na sede da Associação de Defesa do Património Histórico e Cultural do Concelho de Almeirim (A. D.P.H.C.C.A.) (Pimenta, Henriques, Mendes, 2012).

\section{DiACRONIA DA OCUPAÇÃO E PRINCIPAIS ELEMENTOS} DE LEITURA DO SÍTIO

2.1. A origem do sítio romano de Alto dos Cacos: um acampamento militar.

Os dados aferidos a partir do estudo dos materiais recolhidos no início dos anos oitenta, bem como dos recentes trabalhos de prospecção aí conduzidos por um dos signatários (JP), levaram a destacar a relevância que o sítio apresenta em época romana tardo-republicana. É a esta fase que se reporta a maior parte dos materiais, recolhidos durante as destruições de 1981, elevando-se estes a várias centenas de artefactos dos mais diversos tipos.

Os estudos em curso, em torno da colecção de metais, do conjunto numismático, dos artefactos líticos e das cerâmicas importadas, nomeadamente a cerâmica campaniense, lucernas, paredes finas e ânforas, levam-nos a sublinhar a homogeneidade do espólio. Apesar de estes carecerem de quaisquer coordenadas estratigráficas, o conjunto é bastante coerente, reportando-se a uma fase de ocupação em torno aos meados do século I a.C. (Pimenta, Henriques, Mendes, 2012; Silva, Pimenta, Mendes, 2013; Pimenta, Mendes, Henriques, 2014; Guerra, Pimenta, Sequeira, 2014).

As ânforas, em particular, já tinham sido alvo de estudo e publicação preliminar (Pimenta, Henriques, Mendes, 2012); contudo, a sua quantidade face à totalidade do acervo cerâmico do sitio, e o posterior incremento devido à (re)localização e incorporação de outros pequenos lotes dispersos de fragmentos, entretanto aparecidos, converteram esta amostra numa das mais significativas em termos numéricos conhecidas para o ocidente do território actualmente português, facto que justificava automaticamente o seu estudo individualizado.

Dos dados que foi possível compilar e sistematizar até ao momento sobre o sítio de Alto dos Cacos, pode presumir-se que durante o conturbado período que se viveu nos momentos finais da República se tenha aqui edificado um acampamento militar romano de traçado regular. Esta interpretação assenta em três traves mestras, que julgamos bastante sugestivas: a primeira, nos materiais arqueológicos, que permitem sustentar a existência de uma signi- 


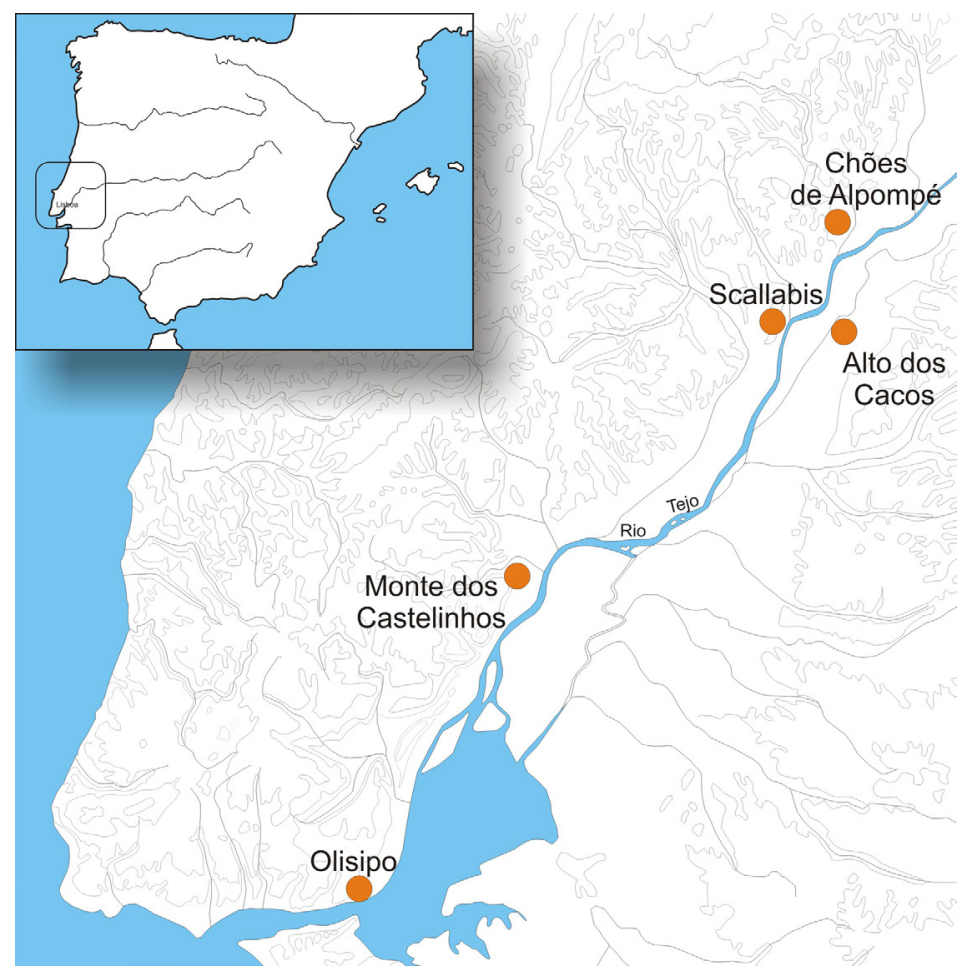

Figura 1. Localização de Alto dos Cacos na Península Ibérica e no Baixo Vale do Tejo.

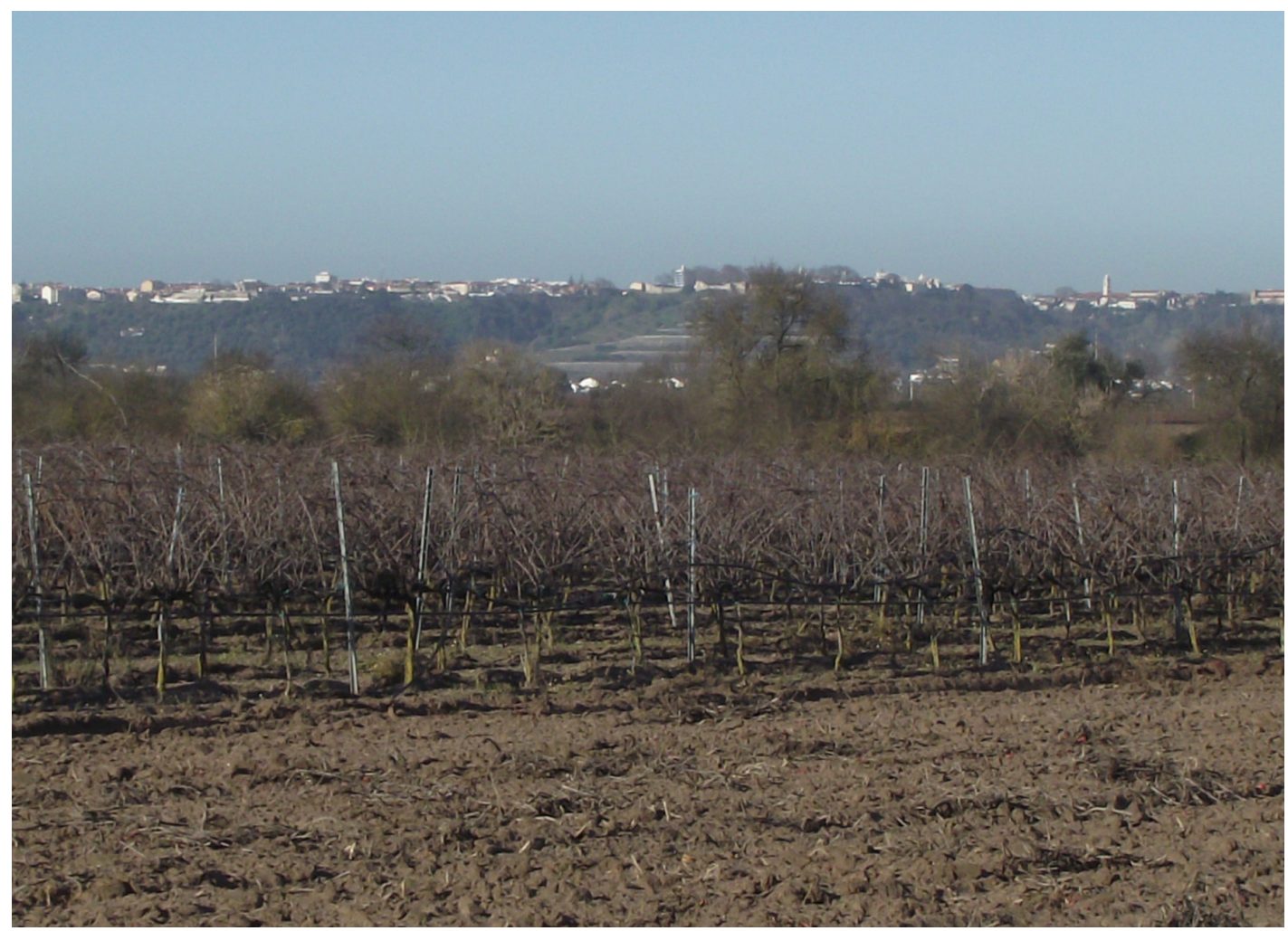

Figura 2. Vista do planalto de Santarém, a antiga Scallabis, na margem direita do Tejo, desde o sítio de Alto dos Cacos. 

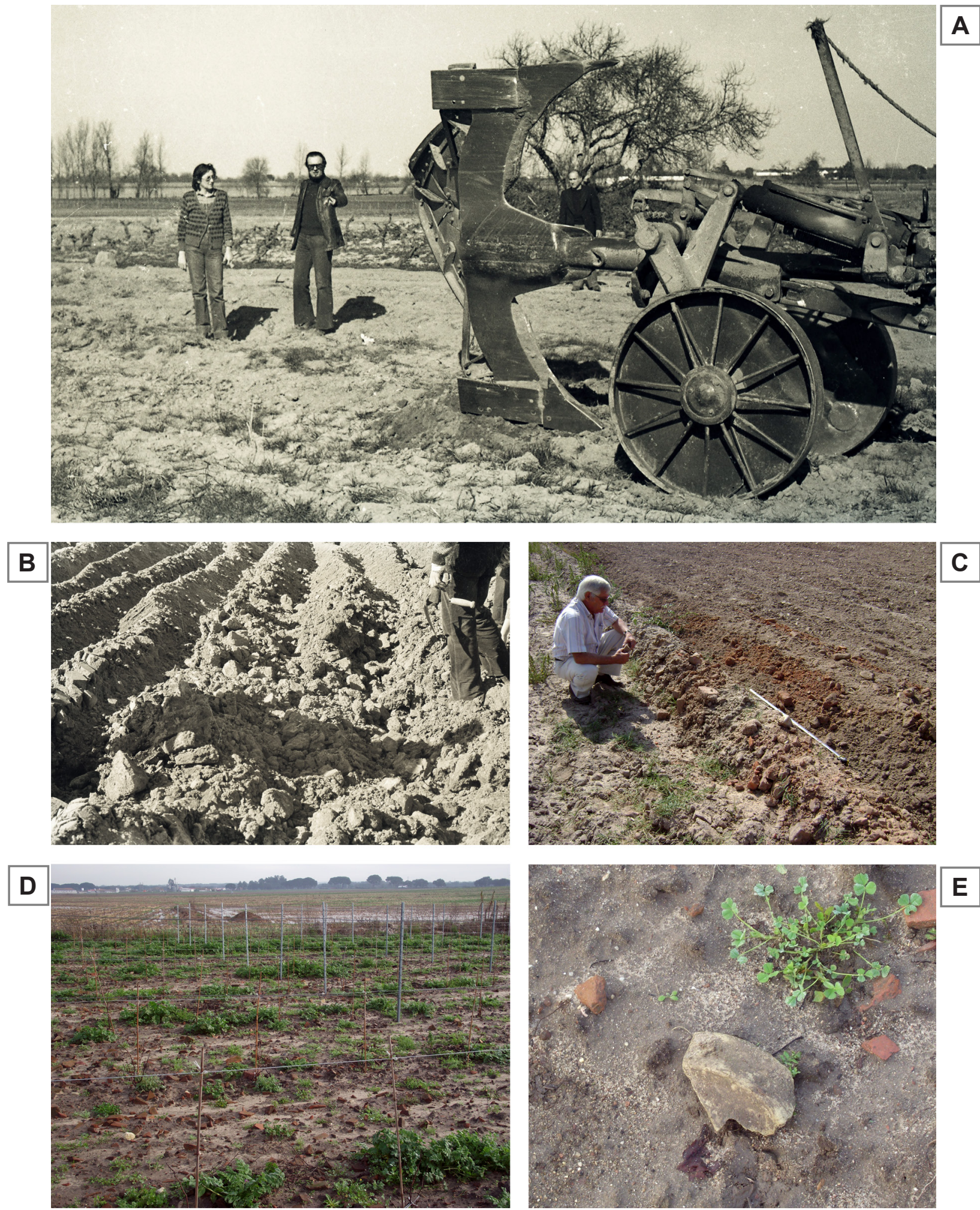

Figura 3. Fragmentos da história do sítio de Alto dos Cacos (de cima para baixo, da esquerda para a direita). A: visita à estação de Alto dos cacos em 1981 pela equipa do organismo que então tutelava a arqueologia - o IPPC; B: estado do terreno em 1981; C: visita em 2010 à estação arqueológica com o seu descobridor, o Dr. Eurico Henriques; D: o estado actual dos terrenos do sítio, ocupados por cultivo de vinha; E: detalhe de bordo de ânfora "ovóide gaditana" in situ. 
ficativa ocupação centrada no terceiro quartel do século I a.C; a segunda, os artefactos bélicos presentes nas coleções depositadas na A.D.P.H.C.C.A. e que atestam uma coesa presença de cariz militar em Alto dos Cacos; a terceira, e última, os dados da fotografia aérea, que permitem vislumbrar, em consonância com o que se vê no terreno, a existência de uma antiga estrutura subrectangular regular de cantos arredondados, rodeada de fossos e possivelmente com muralhas de talude em terra. As dimensões do sítio, com 450 por $260 \mathrm{~m}$, configuram uma extensa área ocupada de cerca 11 hectares, orientada aos pontos cardiais.

Parece-nos, assim, bastante consistente a hipótese de estarmos perante evidências de um acampamento militar romano de traçado regular como nos é descrito por algumas obras da literatura antiga, em especial, para uma época um pouco anterior, por Políbio (Hist. VI. 26.10).

A presença de elementos de armamento itálico em Alto dos Cacos é um dos elementos mais contundentes para a interpretação do sítio como local de estacionamento de tropas romanas. Apesar de estes não terem sido identificados num contexto arqueológico primário, mas sim resultado de recolhas fruto da destruição do sítio nos anos oitenta, é mesmo assim impressionante a sua abundância e estado de conservação (Guerra, Pimenta, Sequeira, 2014). Para esta interpretação contribui ainda o facto, bem conhecido, de Scallabis se ter constituído, talvez desde momentos finais do século II a.C., como um ponto fundamental num conjunto de operações levadas a cabo pelo exército romano. Destaca-se, em particular, para o período correspondente à cronologia dos achados do Alto dos Cacos, a associação daquela cidade às campanhas militares de César na Lusitânia, a que se costuma associar o Praesidium Iulium Scallabis (Viegas, 2003; Almeida, 2008).

Existem, portanto, argumentos arqueológicos e históricos de fundo que nos levam a admitir a interpretação da implantação romana no sítio de Alto dos Cacos com a de um estabelecimento militar. Aguardamos, contudo, que a realização de escavações arqueológicas no local, devidamente enquadradas num programa de estudo direcionado para a caracterização deste estabelecimento, permitam esclarecer a sua funcionalidade e confirmar ou infirmar algumas das hipóteses já avançadas (Pimenta, Mendes, Henriques, 2014).
2.2. Outros episódios de ocupação: entre os finais do I a.C. e a Antiguidade Tardia...

Um conjunto de dados igualmente interessantes da ocupação do sítio de Alto dos Cacos é o que demonstra que este não é definitivamente abandonado nos momentos iniciais do Principado. De facto, entre os materiais provenientes desta estação preserva-se uma coleção coerente, que embora não seja quantitativamente significativa é no entanto relevante, composta por materiais que atestam uma clara ocupação do sítio em momentos posteriores. Este mantém-se "activo" durante os inícios do século I d.C., entrando posteriormente em declínio no decurso da dinastia júlio-cláudia, tornando-se mais notório com os Flávios, para aparentemente ser definitivamente abandonado no século II d.C. (Silva, Pimenta, Mendes, 2013).

A evidência directa dessa ocupação assenta essencialmente em uma significativa colecção de serviços de mesa importados, que nos permitem aferir boas cronologias para a dinâmica das relações aquisitivas do sítio (ver Silva, Pimenta, Mendes, 2013). Tal como na Alcáçova de Santarém (Viegas, 2003), no conjunto de sigillata de Alto dos Cacos identificou-se a presença de sigillata oriental A, atestada por um fragmento de um grande prato da forma Hayes 3. É relevante a sua presença, visto este fabrico de sigillata proveniente do Mediterrâneo Oriental situar-se cronologicamente entre a primeira metade do século I a.C. e o final desse século, tendo chegado a Santarém antes da sigillata de tipo itálico (Viegas, 2003, 41). Essa hipotética sequência de recepção é a que parece "reproduzir-se" em Alto dos Cacos, seguramente através de canais de distribuição comuns.

Por último, encontra-se atestada uma fase de ocupação, ou de reocupação, já em época tardia, num momento indeterminado entre os séculos III e IV d.C. Face aos escassos testemunhos materiais disponíveis, apenas se pode considerar plausível, nesta fase, estarmos já a lidar com outro tipo de utilização do espaço, possivelmente com uma instalação de cariz rural, que se estabelece na mesma zona do outrora acampamento ou nas suas imediações.

\section{O CONJUnto DAS ÂNForas Romanas. Análise E} DISCUSSÃO.

Entre o avultado conjunto de materiais arqueológicos de Alto dos Cacos, na sua grande maioria recolhidos na sequência das já referidas destruições do início dos anos 80 do século XX, sobressaem as 


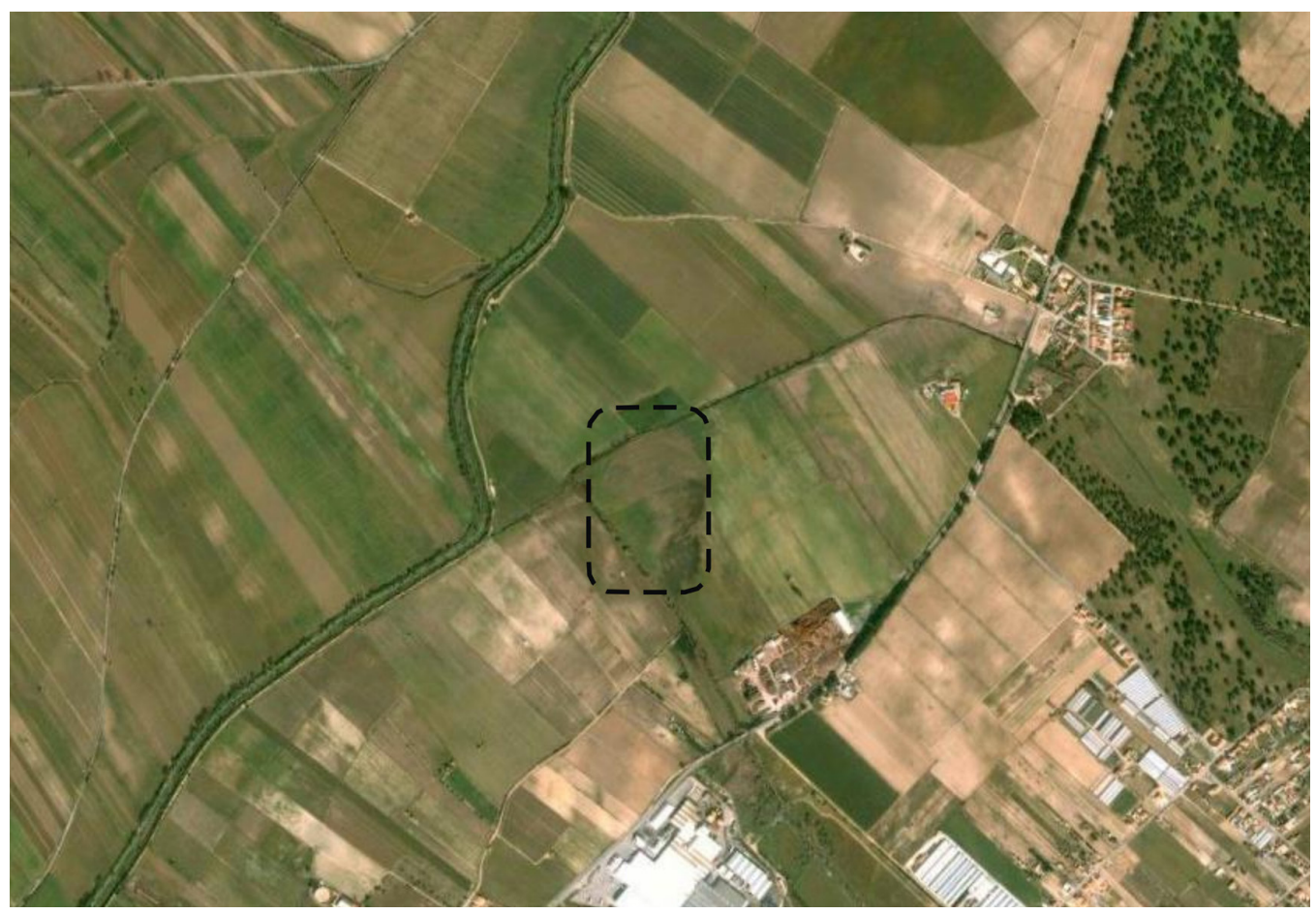

Figura 4. Fotografia aérea do local, com indicação a tracejado das anomalias no terreno, que poderão corresponder aos limites do provável recinto do acampamento militar romano.

ânforas, quer pelo abundantíssimo número, quer pelo seu estado de preservação, em alguns casos óptimo. De facto, desde o primeiro momento que contactámos com a realidade desta estação, fomos surpreendidos pela existência na exposição permanente no Museu da A.D.P.H.C.C.A. de uma grande quantidade de fragmentos de ânforas, alguns deles com a metade superior praticamente intacta, e outros tendo inclusivamente preservados os respectivos tituli picti.

Entre os milhares de fragmentos então recolhidos e armazenados foi possível individualizar um número de 379 fragmentos de ânforas diagnosticáveis e passíveis de ser classificados, cuja análise e estudo resultou ser de 188 o Número Mínimo de Indivíduos (=NMI) quantificado.

\subsection{As importações itálicas}

As ânforas produzidas na Península Itálica trata-se de produções bem conhecidas e estudadas, sendo normalmente conotadas com os primeiros momentos de contactos com o mundo romano, e no caso do ocidente peninsular, correspondente ao atual território português, estão frequente e diretamente relacionadas com o processo tardio de conquista/organização do território peninsular e com circuitos de abastecimento aos exércitos, sobretudo enquadráveis numa etapa terminal da República (Fabião, 1989, 121-125; Fabião, 1998a, 175-176; Arruda, Almeida, 1999; Pimenta, 2005; Bargão, 2006). No conjunto de Alto dos Cacos foram identificados 38 fragmentos oriundos desta macrorregião (11 fragmentos de bordo, 19 arranques de asas/asas e 8 fundos), que correspondem a um NMI de 12 indivíduos, e que representam 6,5\% do total da amostra e 7\% das importações compreendidas entre os finais da República/início do Principado (ver Figuras 5-6).

O tipo melhor representado é a ânfora Dressel 1, o contentor por excelência da exportação do vinho produzido nas grandes villae republicanas da zona da Etrúria, Campânia e Lácio (Tchernia, 1986), cuja produção parece ter-se iniciado nos inícios da segunda metade do século II a.C. e prolongando-se seguramente até à segunda metade do século I a.C., praticamente até à sua última década. Em Alto dos Cacos estão presentes tanto algumas ânforas do tipo Dressel 1 - não só das ditas “variante A”, historiograficamente consideradas mais antigas (Figura 7: AC440, AC346, AC135), mas também das mais 


\begin{tabular}{|c|c|c|c|c|c|c|c|c|c|c|}
\hline Proveniência & & Tipo & Bordo & Arr.A & Asa & Fundo & Frag. & \% Frag. & NMI & $\% \mathrm{NMI}$ \\
\hline \multirow{6}{*}{$\begin{array}{l}\text { Ulterior / Lusitânia, } \\
\text { (vales do Tejo / Sado) }\end{array}$} & \multicolumn{2}{|c|}{ "Lusitanas Antigas" } & 13 & & 7 & 5 & 25 & $6,6 \%$ & 13 & $6,9 \%$ \\
\hline & \multicolumn{2}{|l|}{ Dressel 14} & 1 & 2 & 2 & & 5 & $1,3 \%$ & 1 & $0,5 \%$ \\
\hline & \multicolumn{2}{|c|}{ Almagro 50} & 1 & & & 1 & 2 & $0,5 \%$ & 1 & $0,5 \%$ \\
\hline & \multicolumn{2}{|c|}{ Almagro 51C } & 5 & & 2 & 1 & 8 & $2,1 \%$ & 5 & $2,7 \%$ \\
\hline & \multicolumn{2}{|c|}{ Indeterminado } & & & 1 & 1 & 2 & $0,5 \%$ & 1 & $0,5 \%$ \\
\hline & \multicolumn{2}{|l|}{ Total } & 20 & 0 & 14 & 8 & 42 & $11,1 \%$ & 21 & $11,2 \%$ \\
\hline \multicolumn{3}{|l|}{ Total Ulterior / Lusitânia } & 20 & 0 & 14 & 8 & 42 & $11,1 \%$ & 21 & $11,2 \%$ \\
\hline \multirow{7}{*}{$\begin{array}{l}\text { Ulterior / Bética, } \\
\text { costa sudoeste }\end{array}$} & \multicolumn{2}{|l|}{ Mañá C2b } & 5 & & 1 & 1 & 7 & $1,8 \%$ & 5 & $2,7 \%$ \\
\hline & \multicolumn{2}{|c|}{ "Ovóide Gaditana" } & 16 & & & 1 & 17 & $4,5 \%$ & 16 & $8,5 \%$ \\
\hline & \multicolumn{2}{|c|}{ "Classe 67" } & 7 & & & & 7 & $1,8 \%$ & 7 & $3,7 \%$ \\
\hline & \multicolumn{2}{|c|}{ Dressel 12? } & 2 & & & & 2 & $0,5 \%$ & 2 & $1,1 \%$ \\
\hline & \multicolumn{2}{|c|}{\begin{tabular}{|l|} 
Dressel 7-11 \\
\end{tabular}} & 49 & 10 & 24 & 14 & 97 & $25,6 \%$ & 49 & $26,1 \%$ \\
\hline & \multicolumn{2}{|c|}{ Indeterminado } & & & 9 & 1 & 10 & $2,6 \%$ & 0 & $0,0 \%$ \\
\hline & \multicolumn{2}{|l|}{ Total } & 79 & 10 & 34 & 17 & 140 & $36,9 \%$ & 79 & $42,0 \%$ \\
\hline \multirow{15}{*}{\begin{tabular}{|l} 
Ulterior / Bética, \\
Vale do Guadalquivir
\end{tabular}} & \multicolumn{2}{|l|}{ Ovóide 1} & 2 & & & 1 & 3 & $0,8 \%$ & 2 & $1,1 \%$ \\
\hline & \multicolumn{2}{|l|}{\begin{tabular}{|l|} 
Ovóide 4 \\
\end{tabular}} & 19 & & & & 19 & $5,0 \%$ & 19 & $10,1 \%$ \\
\hline & \multicolumn{2}{|l|}{ Ovóide 5} & 3 & 1 & 2 & & 6 & $1,6 \%$ & 3 & $1,6 \%$ \\
\hline & \multicolumn{2}{|l|}{ Ovóide 6} & 5 & & 1 & & 6 & $1,6 \%$ & 5 & $2,7 \%$ \\
\hline & Ovóide 9 & & 1 & & & & 1 & $0,3 \%$ & 1 & $0,5 \%$ \\
\hline & Ovóide Ind & terminado & & 10 & 15 & & 25 & $6,6 \%$ & $\mathbf{0}$ & $0,0 \%$ \\
\hline & Total Ovói & es tardo-republicanas & 30 & 11 & 18 & 1 & 60 & $15,8 \%$ & 30 & $16,0 \%$ \\
\hline & Haltern 70 & augusto-tiberiana) & 27 & & & & 27 & $7,1 \%$ & 27 & $14,4 \%$ \\
\hline & Haltern 70 & cláudio-neroniana) & 2 & & & & 2 & $0,5 \%$ & 2 & $1,1 \%$ \\
\hline & Haltern 70 & não determinável) & 1 & 6 & 19 & 9 & 35 & $9,2 \%$ & 1 & $0,5 \%$ \\
\hline & Total Halte & $n 70$ & 30 & 6 & 19 & 9 & 64 & $16,9 \%$ & 30 & $16,0 \%$ \\
\hline & Ovóide 7 ( & Oberaden 83 ) & 8 & & 4 & & 12 & $3,2 \%$ & 8 & $4,3 \%$ \\
\hline & Dressel 20 & (júlio-cláudia) & 3 & & 3 & & 6 & $1,6 \%$ & 3 & $1,6 \%$ \\
\hline & Dressel 20 & (não determinável) & & 1 & & & 1 & $0,3 \%$ & 0 & $0,0 \%$ \\
\hline & Total & & 72 & 19 & 52 & 11 & 154 & $40,6 \%$ & 72 & $38,3 \%$ \\
\hline Total Ulterior / Bética & & & 151 & 29 & 86 & 28 & 294 & $77,5 \%$ & 151 & $80,3 \%$ \\
\hline Península Itálica & Greco-itáli & a tardia & 1 & & & & 1 & $0,3 \%$ & 1 & $0,5 \%$ \\
\hline & "Ânforas B & ndisi" * & 1 & & 1 & 1 & 3 & $0,8 \%$ & 2 & $1,1 \%$ \\
\hline & \begin{tabular}{|l} 
Dressel 1 \\
\end{tabular} & & 8 & 2 & 16 & 7 & 33 & $8,7 \%$ & 8 & $4,3 \%$ \\
\hline & Lamboglia & & 1 & & & & 1 & $0,3 \%$ & 1 & $0,5 \%$ \\
\hline * fabricos distintos & Total & & 11 & 2 & 17 & 8 & 38 & $10,0 \%$ & 12 & $6,4 \%$ \\
\hline Indeterminada & Indetermin & & 4 & 1 & & & 5 & $1,3 \%$ & 4 & $2,1 \%$ \\
\hline & Total & & 4 & 1 & 0 & 0 & 5 & $1,3 \%$ & 4 & $2,1 \%$ \\
\hline & Total & & 186 & $\overline{32}$ & 1117 & 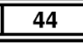 & 379 & $100 \%$ & 188 & $100 \%$ \\
\hline & & & $\begin{array}{l}\text { a tirrénic } \\
\mathbf{5 \%}\end{array}$ & & & & & & & \\
\hline Proveniência & NMI & $\%$ NMI & & & & & & & & \\
\hline Ulterior / Lusitânia & 21 & $11,2 \%$ & & $\begin{array}{l}\text { terior / B } \\
\text { e Guadal }\end{array}$ & & & & & & \\
\hline Ulterior / Bética & 151 & $80,3 \%$ & & $38 \%$ & & & & sta sudoeste & & \\
\hline Peninsula Itálica & 12 & $6,4 \%$ & & & & & & & & \\
\hline Indeterminadas & 4 & $2,1 \%$ & & & & & & & & \\
\hline \begin{tabular}{|l|} 
Total \\
\end{tabular} & 188 & $100 \%$ & & & & & & & & \\
\hline
\end{tabular}

Figura 5. Quantificação total do conjunto de ânforas de Alto dos Cacos e sínteses por áreas e regiões produtoras. 


\begin{tabular}{|c|c|c|c|c|c|c|c|c|c|}
\hline Proveniência & Tipo & Bordo & Arr.A & Asa & Fundo & Frag. & $\%$ Frag. & NMI & $\%$ NMI \\
\hline \multirow{2}{*}{$\begin{array}{l}\text { Ulterior / Lusitânia, } \\
\text { (vales do Tejo / Sado) }\end{array}$} & "Lusitanas Antigas" & 13 & & $\overline{7}$ & $\overline{5}$ & 25 & $9,0 \%$ & 13 & $7,6 \%$ \\
\hline & Total & 13 & 0 & 7 & 5 & 25 & $9,0 \%$ & 13 & $7,6 \%$ \\
\hline \multicolumn{2}{|l|}{ Total Ulterior / Lusitânia } & 13 & 0 & 7 & 5 & 25 & $9,0 \%$ & 13 & $7,6 \%$ \\
\hline \multirow{6}{*}{$\begin{array}{l}\text { Ulterior / Bética, } \\
\text { costa sudoeste }\end{array}$} & Mañá C2b & 5 & & 1 & 1 & 7 & $2,5 \%$ & 5 & $2,9 \%$ \\
\hline & "Ovóide Gaditana" & 16 & & & 1 & 17 & $6,1 \%$ & 16 & $9,4 \%$ \\
\hline & "Classe 67" & 7 & & & & 7 & $2,5 \%$ & 7 & $4,1 \%$ \\
\hline & Dressel 12? & 2 & & & & 2 & $0,7 \%$ & 2 & $1,2 \%$ \\
\hline & Dressel 7-11 & 49 & 10 & 24 & 14 & 97 & $34,9 \%$ & 49 & $28,8 \%$ \\
\hline & Total & 79 & 10 & 25 & 16 & 130 & $46,8 \%$ & 79 & $46,5 \%$ \\
\hline \multirow{8}{*}{$\begin{array}{l}\text { Ulterior / Bética, } \\
\text { Vale do Guadalquivir }\end{array}$} & Ovóide 1 & 2 & & & 1 & 3 & $1,1 \%$ & 2 & $1,2 \%$ \\
\hline & Ovóide 4 & 19 & & & & 19 & $6,8 \%$ & 19 & $11,2 \%$ \\
\hline & Ovóide 5 & 3 & 1 & 2 & & 6 & $2,2 \%$ & 3 & $1,8 \%$ \\
\hline & Ovóide 6 & 5 & & 1 & & 6 & $2,2 \%$ & 5 & $2,9 \%$ \\
\hline & Ovóide 9 & 1 & & & & 1 & $0,4 \%$ & 1 & $0,6 \%$ \\
\hline & Haltern 70 (augusto-tiberiana) & 27 & & & & 27 & $9,7 \%$ & 27 & $15,9 \%$ \\
\hline & Ovóide 7 (=Oberaden 83) & 8 & & 4 & & 12 & $4,3 \%$ & 8 & $4,7 \%$ \\
\hline & Total & 66 & 2 & 15 & 2 & 85 & $30,6 \%$ & 66 & $38,8 \%$ \\
\hline \multicolumn{2}{|l|}{ Total Ulterior / Bética } & 145 & 12 & 40 & 18 & 215 & $77,4 \%$ & 145 & $85,3 \%$ \\
\hline \multirow[t]{5}{*}{ Península Itálica } & Greco-itálica tardia & 1 & & & & 1 & $0,4 \%$ & 1 & $0,6 \%$ \\
\hline & "Ânforas Brindisi" * & 1 & & 1 & 1 & 3 & $1,1 \%$ & 2 & $1,2 \%$ \\
\hline & Dressel 1 & 8 & 2 & 16 & 7 & 33 & $11,9 \%$ & 8 & $4,7 \%$ \\
\hline & Lamboglia 2 & 1 & & & & 1 & $0,4 \%$ & 1 & $0,6 \%$ \\
\hline & Total & 11 & 2 & 17 & 8 & 38 & $13,7 \%$ & 12 & $7,1 \%$ \\
\hline ` fabricos distintos & Total & 169 & 14 & 64 & 31 & 278 & $100 \%$ & 170 & $100 \%$ \\
\hline
\end{tabular}

\begin{tabular}{|c|c|c|}
\hline Proveniência & NMI & $\%$ NMI \\
\hline Ulterior / Lusitânia & 13 & $7,6 \%$ \\
\hline Ulterior / Bética & 145 & $85,3 \%$ \\
\hline Península Itálica & 12 & $7,1 \%$ \\
\hline Total & 170 & $100 \%$ \\
\hline
\end{tabular}

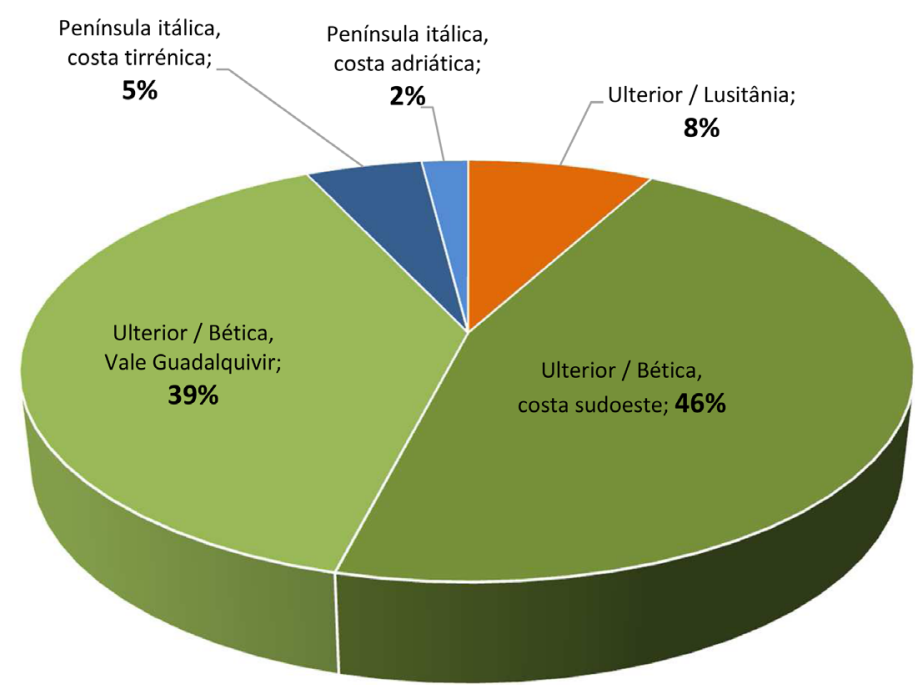

Figura 6. Quantificação das ânforas de Alto dos Cacos atribuíveis ao final da República / início do Principado e sínteses por áreas e regiões produtoras. 
recentes atribuíveis às tradicionalmente designadas "variantes $1 \mathrm{~B}$ e $1 \mathrm{C}$ ", que sabemos conviverem cronologicamente, e para as quais, ante a ausência de dados contextuais, apenas se podem balizar de uma forma lata entre 125-25 a.C., bem como um exemplar de "Greco-Itálica tardia" (Figura 7: AC442). Para este último fragmento não nos é totalmente claro qual o seu enquadramento cronológico, podendo mesmo estar ainda conotado com o povoado indígena que existiria neste local antes do estabelecimento romano (Sousa et al., 2016-2017).

Refira-se também que a observação macroscópica dos exemplares atribuíveis a ambos tipos itálicos permitiu registar presença quer de fabricos da área campana (de pastas acastanhadas escuras, com abundantes elementos minerais negros vulcânicos), o principal foco exportador destes contentores, quer de outros fabricos, com pastas homogéneas e compactas, com tonalidades avermelhadas e abundantes desengordurantes, de distinta natureza, com calibre médio e pequeno (cf. Pimenta, 2005), que sugerem uma proveniência tirrénica septentrional.

Os contentores vinários do tipo Dressel 1 representam aproximadamente $75 \%$ do total dos contentores itálicos, o denominador constante em muitos outros sítios e conjuntos coevos do actual território português, embora em valores inferiores aos habituais. Ao mesmo tempo, face à totalidade da amostra de Alto dos Cacos, esta componente itálica vê reforçado o seu carácter "anómalo", na medida em que se encontra bastante sub-representada, apenas um parcial de 4,3\% do NMI identificado, contrastando sobremaneira com a hegemonia atestada em outros contextos tardo-republicanos como os da cidade de Lisboa (Pimenta, 2005; Mota, Pimenta, Silva, 2014; Pimenta et al., 2014), Chões de Alpompé (Fabião, 1989; Diogo, Trindade, 1993-94; Pimenta, Arruda, 2014) e especialmente Santarém (Arruda, Almeida, 1999; Arruda, Almeida, 2001; Bargão, 2006; Almeida, 2008), para citar os mais próximos, ou ainda outros mais distantes como Lomba do Canho (Fabião, 1989), Mesas do Castelinho (Parreira, 2009), Monte Molião (Arruda, Sousa, 2013), Faro ou Castro Marim (Viegas, 2011). Tal leitura configura, no nosso ponto de vista, uma questão cronológica: o sítio de Alto dos Cacos atesta um padrão de consumo de produtos alimentares itálicos já de momentos terminais da República, podendo mesmo entrar nos primeiros anos do Principado, quando as importações do vinho italiano se encontram em declínio acentuado (Fabião, 1998a, 180-182; Arru- da, Almeida, 1999; Arruda, Almeida, 2001; Bargão, 2006), mas em que ainda estão presentes, concretamente no período compreendido entre 30-15 a.C., tal como é sabido por inúmeros outros locais de consumo, quer no âmbito da Hispania (Bernal Casasola, García Vargas, Sáez Romero, 2013, esp. 362363; Mateo Corredor, 2016), quer sobretudo no do Mediterrâneo ocidental, particularmente na Gália e nos acampamentos das fronteiras germanas (Reno e Danúbio), onde se encontram contextualmente melhor documentados, sequenciados e estudados (cf. Desbat, Martin-Kilcher, 1989; Martin-Kilcher, 1994; Martin-Kilcher et al., 2013, 396; Ehmig, 2010; Ehmig, 2013, 373; González Cesteros, Tremmel, 2013, 530; González Cesteros, 2014).

Para além das omnipresentes produções tirrénicas, foram ainda identificados no conjunto de Alto dos Cacos alguns fragmentos que pertencem indubitavelmente a tipos manufaturados na região meridional e adriática, concretamente aos tipos ditos de "Brindisi" (Figura 7: AC05, AC150, AC906) e um fragmento de bocal de uma Lamboglia 2 (Figura 7: AC1010).

Os primeiros, cuja denominação costuma agrupar vários tipos ou uma "família de tipos”, de grande diversidade formal, foram produzidos sobretudo nos centros oleiros dessa cidade epónima, mas também em muitos outros da Apúlia e da Calábria, no sul da Península Itálica, entre meados do século II e os meados do I a.C., tendo-se destinado ao transporte do azeite (Cipriano, Carré, 1989; Manacorda, 1994; Manacorda, Pallechi, 2012; Palazzo, 2013). O bordo AC906, assim como a asa AC05 pertencem ao tipo III de Apani, um dos tipos integrantes da denominada "produção Vehiliana". Tal epíteto deve-se ao facto de a maior parte dos exemplares de estas ânforas apresentarem frequentemente impressa numa das suas asas a marca VEHILI, que pode aparecer com várias variantes onomásticas, todas elas pertencentes a um personagem de nome C. Vehilius, associada a outras de nomes de vários escravos que operavam na officina Vehiliana $(\mathrm{Pa}-$ lazzo, 2013, 27-28).

Neste contexto, merece especial destaque o fragmento AC05 pela particularidade de preservar precisamente a marca VEHILI, e que foi recentemente alvo de publicação (Fabião et al., 2016, no 31). Impressa numa matriz quadrangular (Figura 7 ), parece corresponder aos punções F2-F4 de Apani (Palazzo, 2013, 73-75). Trata-se, portanto, de uma das marcas melhor representadas e atestadas na epigrafia anfó- 


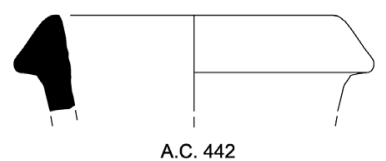

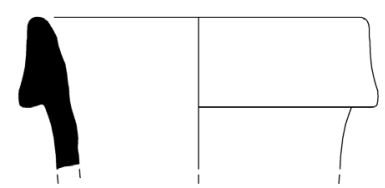

A.C. 440

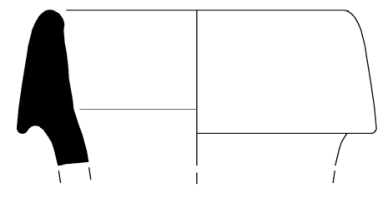

A.C. 441

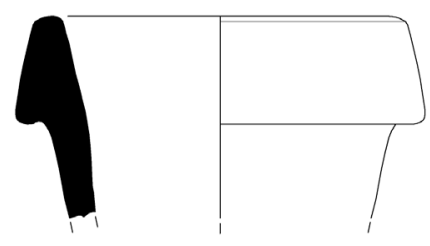

A.C. 346

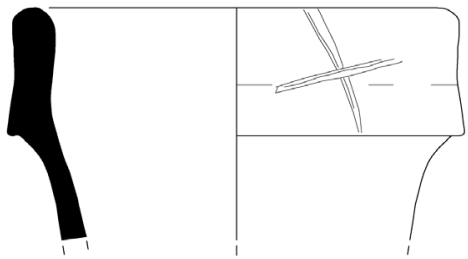

A.C. 144

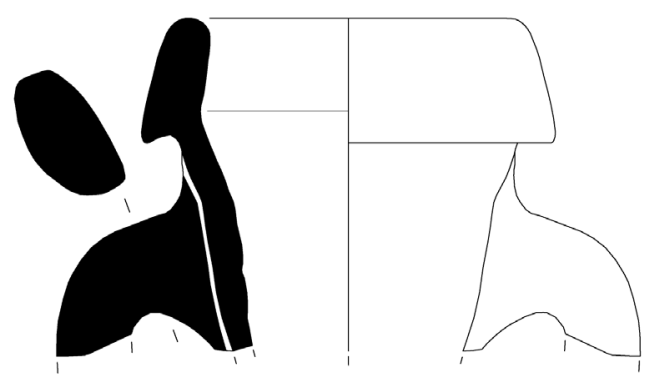

A.C. 145

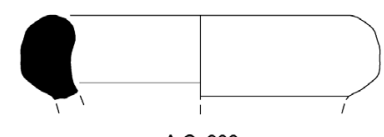

A.C. 906

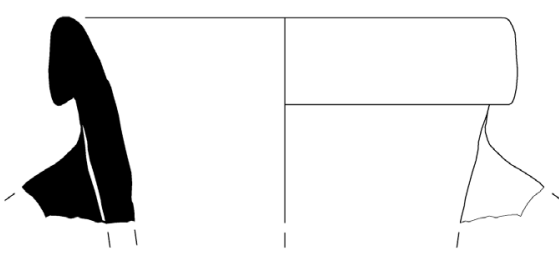

A.C. 1010

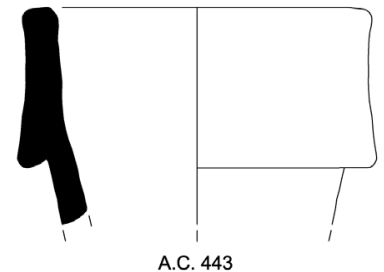

A.C. 443

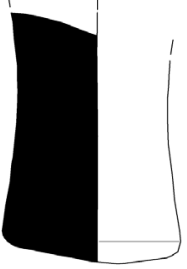

A.C. 167

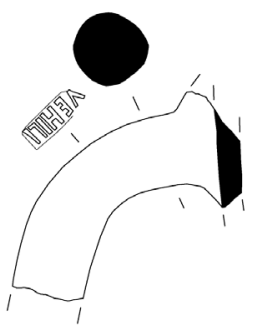

A.C. 05

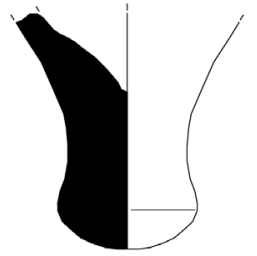

A.C. 150

Figura 7. Ânforas itálicas, costa tirrénica. Greco-itálica tardia: 442; Dressel 1: 440, 346, 135, 441, 144, 145, 443, 166. Ânforas itálicas, costa meridional/adriática. Ânforas de Brindisi: 906, 05, 150; Lamboglia 2: 1010. 
rica brindisina (Desy, 1989) utilizada tanto na olaria de Apani como na de La Rosa, com um marco cronológico estabelecido atualmente na primeira metade do século I a.C. (Palazzo, 2013, 68). Surge em sítios de referência obrigatória no contexto peninsular como Azaila (Beltrán Lloris, 1970), Badalona (Comas I Solá, 1985), Ilici (Marquéz Villora, Molina Vidal, 2001) ou em Ampurias em contextos bem datados de cerca de 50 a.C. (Beltrán Lloris, 1970; Aquilué et al., 2002), todos eles na Citerior Tarraconensis, sendo o exemplar de Alto dos Cacos o mais ocidental dado a conhecer até ao momento.

As ânforas ditas de Brindisi são relativamente raras na Hispânia, de um modo geral, surgindo em quantidades muito reduzidas, e mais ainda na sua metade ocidental, em particular na área correspondente ao actual território português (cf. Carreras Monfort et al., 2016, para uma síntese actualizada da sua distribuição). Em Alto dos Cacos confirma-se isso mesmo; embora alcancem valores nada despiciendos em termos de importações itálicas (25\%), este não deixa de ser ínfimo no total do conjunto (1,6\% do NMI). A sua presença está também atestada em Lisboa, no Castelo de S. Jorge e na Rua do Recolhimento, ambos em contextos mais antigos (Pimenta, 2005; Mota, Pimenta, Silva, 2014) e na vizinha cidade de Santarém (Bargão, 2006, 50-51); nesta última, foram ainda recolhidas mais duas marcas: a bem conhecida MENA (Diogo, 1984) e outra desconhecida onde se pode ler PHILIPVS BET (Bargão, 2006, 53). Ainda segundo esta autora “(...) parece que a sua distribuição e comercialização, para além de estar claramente associada à chegada e presença de contingentes militares no vale do Tejo, surge num âmbito de distribuição diferente da sua congénere Lamboglia 2, parecendo clara a associação desta forma a recipientes vinários produzidos nas costa tirrénica no final do século II a.C., como as formas Greco-itálica e a Dressel 1 (...)" (Bargão, 2006, 51). Não obstante, no caso do Alto dos Cacos, um "horizonte cronológico" aparentemente mais tardio em torno a meados do século I a.C., a associação com Lamboglia 2, igualmente minoritária, parece corresponder a uma distribuição diferente dos produtos itálicos, própria desse momento, em que ambos contentores de produção na Itália meridional surgem em "pack", em proporções muito semelhantes, acompanhando as derradeiras exportações das Dressel 1 tirrénicas.

Por sua vez, o exemplar AC1010 (Figura 7) corresponde a dois fragmentos com colagem de um bordo com arranque de asa de uma ânfora Lamboglia 2, um contentor da Itália adriática de época tardo-republicana formalmente inspirado no tipo Greco-itálico. É hoje em dia comumente aceite, graças aos restos de conteúdos recuperados em vários exemplares do naufrágio de La Madrague de Giens (Tchernia, Pomey, Hesnard, 1978), que se tratava de um envase preferencialmente destinado ao transporte de vinho.

As ânforas deste tipo identificam-se actualmente com uma bem documentada, numerosa e diversificada produção na costa italiana do Adriático (Cipriano, Carré, 1989; Carré et al., 2014; Pesavento Mattioli, 2014; Cipriano, Mazzochin, 2017), com particular concentração na sua metade mais setentrional, mas também com uma conhecida produção na zona da Apúlia (Cipriano, Carré, 1989, 83; Panella 2010, 96-97; Manacorda, Pallechi, 2012, 146148; Palazzo, 2013, 14-15). Foi ainda produzida de forma minoritária na Itália tirrénica, concretamente na Campânia (Hesnard, 1998, 307-310) e Etruria (Berti, 1998). A sua produção encontra-se definida entre o último quartel do século II a.C. e o início do principado de Augusto, mas tendo na primeira metade do século I a.C. o seu período de maior profusão (Empereur, Hesnard, 1987, 33).

A sua comercialização evidencia uma ampla difusão tanto no Mediterrâneo Oriental como no Ocidental. Contudo, constata-se de maneira transversal na metade ocidental que este tipo ocorre em número infinitamente menor que as ânforas vinárias do tipo Dressel 1 (Fabião, 1987; Molina Vidal, 1997), com a notável excepção do sudeste peninsular, concretamente a área de Carthago Nova/Cartagena (Molina Vidal, 1997; Molina Vidal, 2013; Mateo Corredor, 2016) e Málaga, e em menor medida a do sudoeste peninsular, concretamente a área de Cádis, as principais áreas portuárias do sul da Hispania no século I a.C. que parecem ter funcionado como importantes áreas de influência e distribuição das mercadorias adriáticas (Mateo Corredor, 2016, 276-281).

$\mathrm{O}$ actual território português inscreve-se no panorama traçado, encontrando-se estes contentores recorrentemente pouco representados, embora não tanto como os tipos ovóides de Brindisi. A leitura da geografia da sua dispersão, permite sublinhar, uma vez mais, uma particular concentração da sua presença no vale do Tejo, onde surgem em Lisboa (Pimenta, 2005; Filipe, 2015), Santarém (Arruda, 2002, 126; Bargão, 2006, 41-42; Arruda, Viegas, 2014, 248) e Chões de Alpompé (Fabião, 1989; Dio- 
go, Trindade, 1993-1994; Pimenta, Arruda, 2014), mas sobretudo na região meridional correspondente ao actual Algarve, particularmente na sua área central e metade oriental, em torno à foz do Guadiana e à sua área de penetração e influência imediata, justamente a área mais próxima e sob maior influência da cidade de Cádis. Assim, a sua presença está documentada em Faro (Viegas, 2011) e em Castro Marim, o sítio com maior quantidade deste tipo de ânforas, integrando contextos datados entre 6030 a.C. (Arruda, Almeida, 1999, 330; Viegas, 2011), mas com o caso mais paradigmático no chamado depósito de Mértola, datado da primeira metade do século I a.C. (Fabião, 1987); nas áreas de penetração temos os exemplos do povoado de Mesas do Castelinho, Almodôvar (Fabião, Guerra, 1994; Parreira, 2009), integrando contextos datados dos três primeiros quartéis do século I a.C., ou ainda do Castelo das Juntas, em Castro Verde (Madeira, 1986), sem que a classificação ou o contexto sejam seguros. Para ocidente, conhece-se a sua presença em Monte Molião (Arruda, Sousa, 2013), descontextualizada, mas certamente posterior ao $1^{\circ}$ quartel do século I a.C. Mais para ocidente, subindo já a costa da fachada ocidental atlântica e seguramente atribuível a um contexto de naufrágio, é a peça recuperada ao largo do cabo Sardão (Diogo, 1999).

O exemplar proveniente de Alto dos Cacos, que representa $8 \%$ das ânforas itálicas, mas apenas $0,5 \%$ do total do NMI da amostra e 0,6\% do consumo entre os finais da República/início do Principado (ver Figuras 5-6), não altera absolutamente em nada o que antes se referiu; antes pelo contrário, os valores e associações documentados corroboram a leitura da fraca componente nos circuitos de abastecimento ocidentais, e ao Vale do Tejo em particular, que, ainda assim, parece assistir a um ligeiro incremento no terço central do século I a.C.

\subsection{As importações da Ulterior/Bética}

Desde uma primeira tomada de contacto e observação preliminar do conjunto, teve-se uma clara percepção da importância que tinham as ânforas provenientes dos diferentes âmbitos produtores hispânicos, com uma preponderância avassaladora dos tipos e produtos da área sudoeste da Ulterior, e posterior Bética, particularmente da sua área costeira ocidental, genérica e maioritariamente atribuível à geografia da baía de Cádis, e da região interior correspondente ao Vale do Guadalquivir. O estudo detalhado e a posterior quantificação do conjunto vieram a confirmar essa leitura empírica inicial, concluindo-se que contabilizavam 294 fragmentos, correspondentes a $151 \mathrm{NMI}$, o que representa $80 \%$ do total do conjunto e $85 \%$ dos contentores recebidos/consumidos entre os finais da República e os primeiros momentos do Principado (ver Figuras 5-6). As ânforas com estas proveniências repartem-se praticamente de forma equitativa no conjunto, entre os $42 \%$ da área costeira e os $38,3 \%$ do Vale do Guadalquivir.

Estes valores, que se podem arredondar e resumir como superando os $4 / 5 \mathrm{da}$ amostra, atestam um padrão de consumo de produtos alimentares grosso modo concordante com o detectado para a Alcáçova de Santarém, o sítio mais próximo e ao qual seria espectável que correspondesse, em termos de abastecimento, entre meados do século I a.C. e os momentos iniciais do Império (Arruda, Almeida, 1998; Arruda, Almeida, 1999; Arruda, Almeida, 2001; Arruda, Viegas, Bargão, 2005; Almeida, 2008).

\subsubsection{Região costeira da Ulterior/Bética}

As ânforas da costa da Ulterior/Bética recuperadas até ao momento em Alto dos Cacos correspondem exclusivamente a tipos destinados ao transporte de preparados piscícolas. As várias petrografias documentadas permitem afirmar, com relativa segurança, que provêm todas da costa sudoeste dessa província, concretamente das olarias e das inúmeras fábricas de salga localizadas na ampla área que genericamente se denomina como "Baía de Cádis". O seu número ascende a 140 fragmentos classificáveis, correspondendo a um NMI de 79 indivíduos, 42\% do total do conjunto e $46 \%$ do consumo compreendido entre os finais da República/início do Principado (ver Figuras 5-6). Da sua análise sobressaem de imediato dois grandes aspectos, duas linhas de problemática, cujo comentário entendemos ser do maior interesse.

O primeiro, resulta da constatação da presença dos característicos contentores Mañá C2b (T-7.4.3.2/T-7.4.3.3) (Ramon Torres, 1995) (Figura 8) e, simultaneamente, da sua escassa representatividade (ver Figuras 5 e 6). Sabemos actualmente que este contentor, durante muito tempo considerado e conotado unicamente como produção africana "neo-púnica", tem no ocidente hispânico, concretamente na área da Baía de Cádis (Cádis, Puerto Real, Puerto de Santa Maria e campiña, aparentemente extensível ao Baixo Guadalquivir), 
um dos maiores focos produtores conhecidos, tal como nos tem vindo a demonstrar a investigação desenvolvida nas duas últimas décadas (Perdigones Moreno, Muñoz Vicente, 1988; Lagóstena Barrios, 1996a; Lagóstena Barrios, 1996b; García Vargas, 1998; Montero Fernández et al., 2004, 418-421; Bernal Casasola, Lagóstena Barrios, 2004, 86-88, figs. 71-73; Sáez Romero et al., 2016), com uma cronologia de laboração/exportação compreendida entre o último terço do século II a.C. e a mudança da Era (García Vargas, 1998, 67-68; Arruda, Almeida, 1998, 206; Montero Fernández et al., 2004, 418- 421; Sáez Romero et al., 2016).

Embora se discuta o seu conteúdo e se considere o seu possível uso como contentor multifuncional, sabe-se que terá transportado, pelo menos, preparados piscícolas e vinho - como se pode aferir dos tituli picti de halex recolhidos em exemplares da Fossa Aggeris e do Castro Pretório, em Roma, ou do titulus pictus que alude a um conteúdo vinícola proveniente de Mesas de Asta (García Vargas, 1998, 68; Sáez Romero et al., 2016), sendo genericamente aceite que deverão ter sido os primeiros os preferencialmente exportados.

Mas, tal como referimos, entre a ampla amostragem disponível de Alto dos Cacos só se identificaram 7 fragmentos deste tipo, correspondendo a 5 NMI e a $2,7 \%$ do total da amostra. Tal não deixa de ser peculiar, especialmente se atendermos à leitura que temos, do outro lado do rio Tejo, para a Alcáçova de Santarém/Scallabis. Aí, assiste-se a uma ampla representatividade desta forma, sendo a Mañá C2b (T-7.4.3.2/T-7.4.3.3) um dos tipos dominantes no registo arqueológico, o contentor por excelência destinado à comercialização dos preparados piscícolas aí recebidos/consumidos durante o segundo e o terceiro quarteis do século I a.C., cujo volume de comercialização apenas é equiparável ao alcançado de perto pelo da importação das ânforas vinárias itálicas (Arruda, Almeida, 1998; Arruda, Almeida, 1999; Arruda, Viegas, Bargão, 2005, 294; Arruda, Viegas, 2014, 247-249). A provável explicação, para esta distinta leitura, pode talvez ser encontrada, uma vez mais, no enquadramento cronológico do sítio de Alto dos Cacos, cujo apogeu parece centrar-se na segunda metade do século I a.C., ou na natureza/especificidades dos abastecimentos aí realizados... Voltaremos a esta questão mais adiante.

O segundo aspecto, sem dúvida o mais assinalável no que concerne aos tipos anfóricos da Hispania e aos da produção costeira da Ulterior Bética, é a pre- sença maioritária de fragmentos com características formais atribuíveis e relacionadas com contentores de "tipo ovóide" e de outros integráveis nas primeiras formas da "família das Dressel 7 a 11". Devemos ter bem presente que o amplo e complexo universo formal de ambas "famílias de tipos" apresenta, ainda hoje, evidentes limitações ao nível da sua correta caracterização/identificação. De facto, as fronteiras entre as formas ovóides gaditanas e as formas "Dressel 7-11" iniciais são muitas vezes morfologicamente pouco claras. Tal como oportunamente sublinhou E. García Vargas, frequentemente não existe uma verdadeira distinção formal entre a generalidade das ânforas ditas “ovóides” e as ânforas de morfologia ovóide do tipo Dressel 10C, de cronologia mais tardia, dado que essa diferença apenas pode ser valorizada tendo em conta o ambiente produtivo e a dinâmica comercial e cronológica de ambas as produções (García Vargas, 1998, 75 e 91); assim, somos conscientes que na tentativa de classificação desse tipo de peças, sobretudo numa realidade composta por especimenes fragmentários como aquela com que trabalhamos, uma parte dos fragmentos agora apresentados pode efetivamente pertencer a ânforas "ovóides gaditanas" propriamente ditas, mas que outra grande parte pode já ser integrada em formas que se têm vindo a considerar como sendo as iniciais da produção dos tipos Dressel 7, 9 ou 10, que, por sua vez, têm notórias afinidades e reminiscências das precedentes produções ovóides.

Conjuntamente, ambas "famílias de tipos" contabilizam 114 fragmentos, correspondente a 65 NMI, o que representa $35 \%$ do total do conjunto e 38\% dos contentores recebidos/consumidos entre os finais da República os primeiros momentos do Principado (ver Figuras 5-6). Dentro de este grande conjunto, em primeiro lugar destacamos os fragmentos que pertencem claramente a "ovóides gaditanas" (Figura 8: AC156, 13, 126, 402, 344), muitas vezes também designadas por "Dressel 10 arcaicas", que representam 10\% das ânforas da Ulterior/Bética, cerca de 1/5 das ânforas da costa sudoeste dessa província e 8,5\% do conjunto (ver Figuras 5-6 e 8).

As “ovóides gaditanas”, definidas há já quase duas décadas (García Vargas, 1996), mas que dada a escassez de exemplares completos e contextos cronológicos seguros, ainda hoje carecem de uma caracterização mais precisa, apesar das últimas tentativas feitas nessa direção (García Vargas, 1998; García Vargas, Almeida, González Cesteros, 2011; García Vargas, González Cesteros, Almeida, 
no prelo; García Vargas, Sáez Romero, no prelo). Consideram-se o primeiro "grupo" de ânforas de tipologia romana "com personalidade propria" da costa da Ulterior, surgido na primeira metade do século I a.C. e com maior visibilidade a partir do segundo quartel dessa centúria. A sua produção na área da baía gaditana é hoje uma realidade incontestável, sendo conhecida em várias olarias, a maior parte apenas por prospecção (Lagóstena Barrios, 1996a; Lagóstena Barrios, 1996b; García Vargas, 1998), recorrentemente associadas a reproduções de tipos itálicos Dressel 1C e outras formas hispânicas romanizadas como as Dressel 12 e Classe 67. Os escassos casos escavados que ilustram este contexto produtivo podem ser observados na calle Gregório Marañon em Cádis (García Vargas, 1998), Gallineras (García Vargas, 1998), Rabatun (García Vargas, López Rosendo, 2008) ou Jardin del Cano (López Rosendo, 2008; 2010).

Para além de um característico corpo ovóide, as ânforas integráveis neste grupo apresentam bordos maciços e curtos (tal como os seus colos e fundos), sinais inegáveis de uma relação formal com tipos contemporâneos produzidos na área do Vale do Guadalquivir, mas muitas vezes com indícios de um desenho ligeiramente aberto para o exterior, preludiando os perfis mais moldurados que surgirão com as morfologias dos tipos 7-11 de Dressel (García Vargas, 1996, 62; García Vargas, 2001, 66; García Vargas, López Rosendo, 2008, 293).

Relativamente ao hipotético conteúdo transportado, tem vindo a assumir-se, por analogia com a Dressel 10, considerada a sua "sucessora directa", e pelas suas características puramente morfológicas, que os preparados de peixe são uma forte possibilidade (García Vargas, 2001, 66). Recentemente, tentando-se encontrar na forma um argumento funcional para a compreensão/aferição do conteúdo, referiu-se que pelo facto de possuírem bocas bastante abertas, colos largos com asas curtas e fundos ocos, as produções ovóides gaditanas poderiam representar uma adaptação da forma aos conteúdos piscícolas, na medida em que permitiam uma extração mais fácil de um tipo de conteúdo (ou conteúdos) que é em grande parte sólido (pedaços de peixe em salga ou salmoura) ou semi-sólido (molhos que deviam ser geralmente espessos e/ou gelatinosos) (García Vargas, Almeida, González Cesteros, 2011, 258).

Finalmente, ainda no que diz respeito a este tipo, é imperativo comentar que são também par- cos os dados relativos à sua identificação no actual território português. De facto, até ao momento só temos constância (entenda-se publicados como tal...) da sua localização/recepção em três sítios do espaço da futura província da Lusitânia: dois no interior e na bacia do Guadiana - Castelo da Lousa, Mourão (Morais, 2010) e Rocha da Mina, Alandroal (Mataloto, Williams, Roque, 2016) - e outro no Vale do Tejo - Monte dos Castelinhos (Pimenta, Mendes, 2014) - todos eles sítios com cariz militar, em contexto do segundo terço do século I a.C. Entendemos a baixa frequência/densidade de achados como resultado directo, naturalmente, dos problemas de caracterização e identificação do tipo. É desde esta perspectiva que se estranha e se entende a sua aparente ausência em Santarém; aparente porque consideramos que vários fragmentos de aí provenientes e classificados como Dressel 12 e "Dressel 7-11, Grupo I” (Arruda, Viegas, Bargão, 2005, 287-291) correspondem, na realidade, a exemplares de ovóides gaditanas.

Pertencentes também às "primeiras formas romanizadas", ao mesmo universo do primeiro horizonte de romanización de la morfología anfórica gaditana (80/70-40/30 a.C.) (García Vargas, Almeida, González Cesteros, 2011, 258) são alguns fragmentos de Classe 67 (=Lomba do Canho 67/ Sala I), mas cujas pastas certificam uma produção e origem na área da costa (ver Figura 8); segundo proposta recente, esta produção entende-se como uma "cópia” regional da forma produzida no Vale do Guadalquivir (García Vargas, Almeida, González Cesteros, 2011, 258). Sobre este último tipo retomaremos mais adiante... Ainda assim, é de salientar o facto da produção costeira deste tipo se encontrar em Alto dos Cacos em maior número que a sua congénere Ovóide 1 do Guadalquivir, correspondendo ao terceiro tipo mais representado da costa da Ulterior Bética (tal como parece ocorrer em Monte dos Castelinhos (Pimenta, 2015)), correspondendo a 3,7\% do total do NMI e a $4,1 \%$ dos contentores atribuíveis ao final da República/início do Principado (ver Figuras 6 e 8).

Mais problemático (se é que podemos falar nestes termos...) é o caso do grande lote de peças que genericamente podemos considerar como pertencendo à "família" de ânforas Dressel 7 a 11. A importância que detêm no conjunto das importações/consumo de Alto dos Cacos é verdadeiramente significativa, correspondendo a cerca de $60 \%$ das ânforas de salga da costa da Ulterior/Bética, a $26 \%$ do conjunto e a 

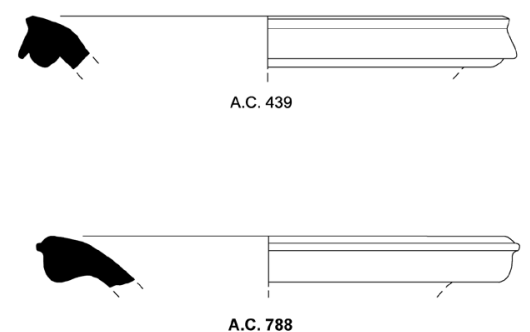

A.C. 788
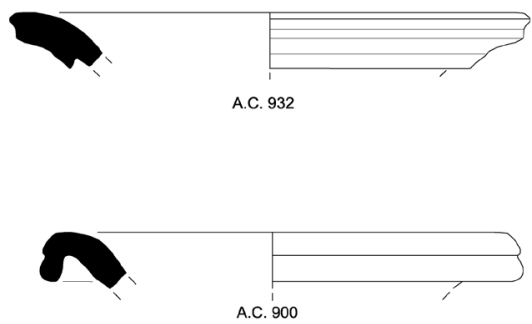

A.C. 900
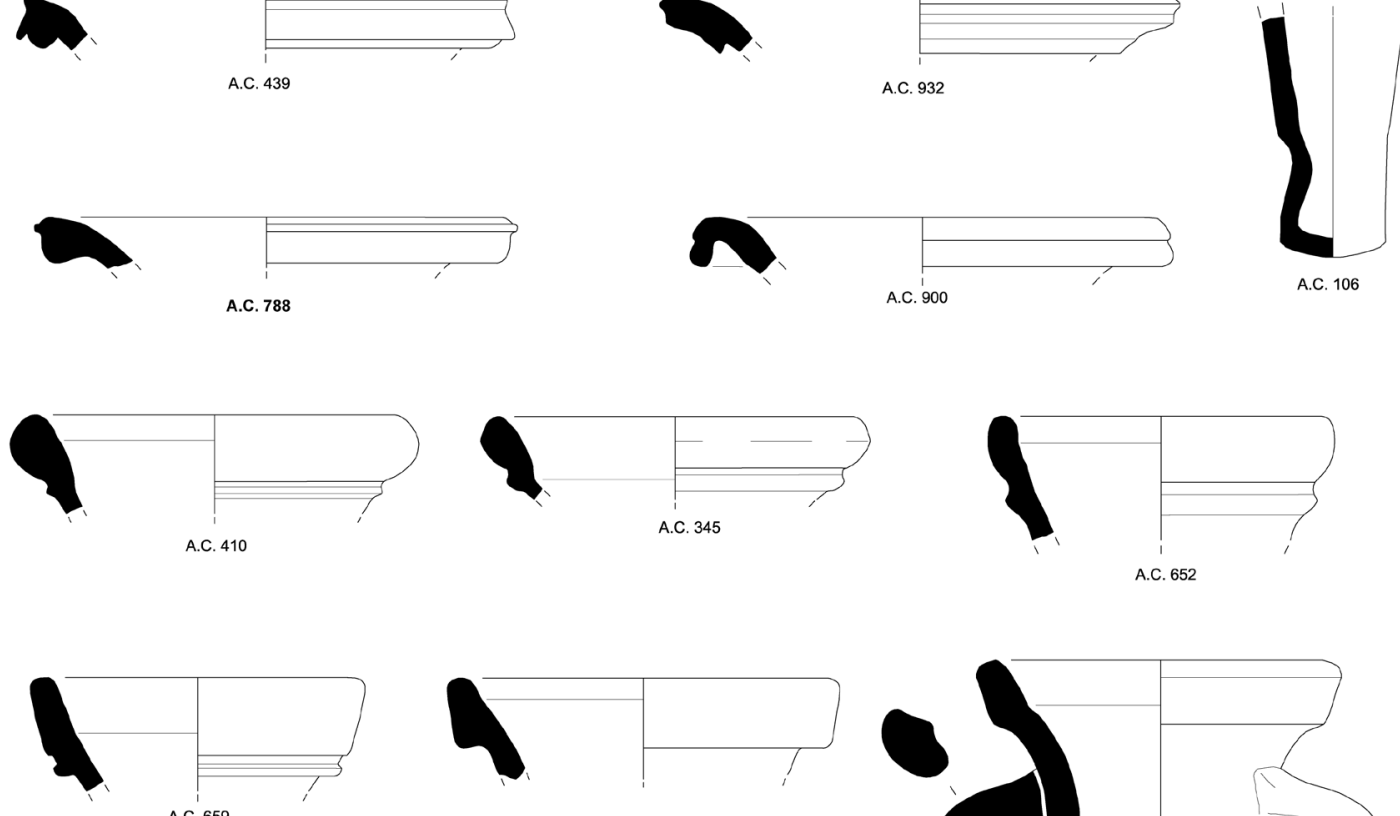

AC 156
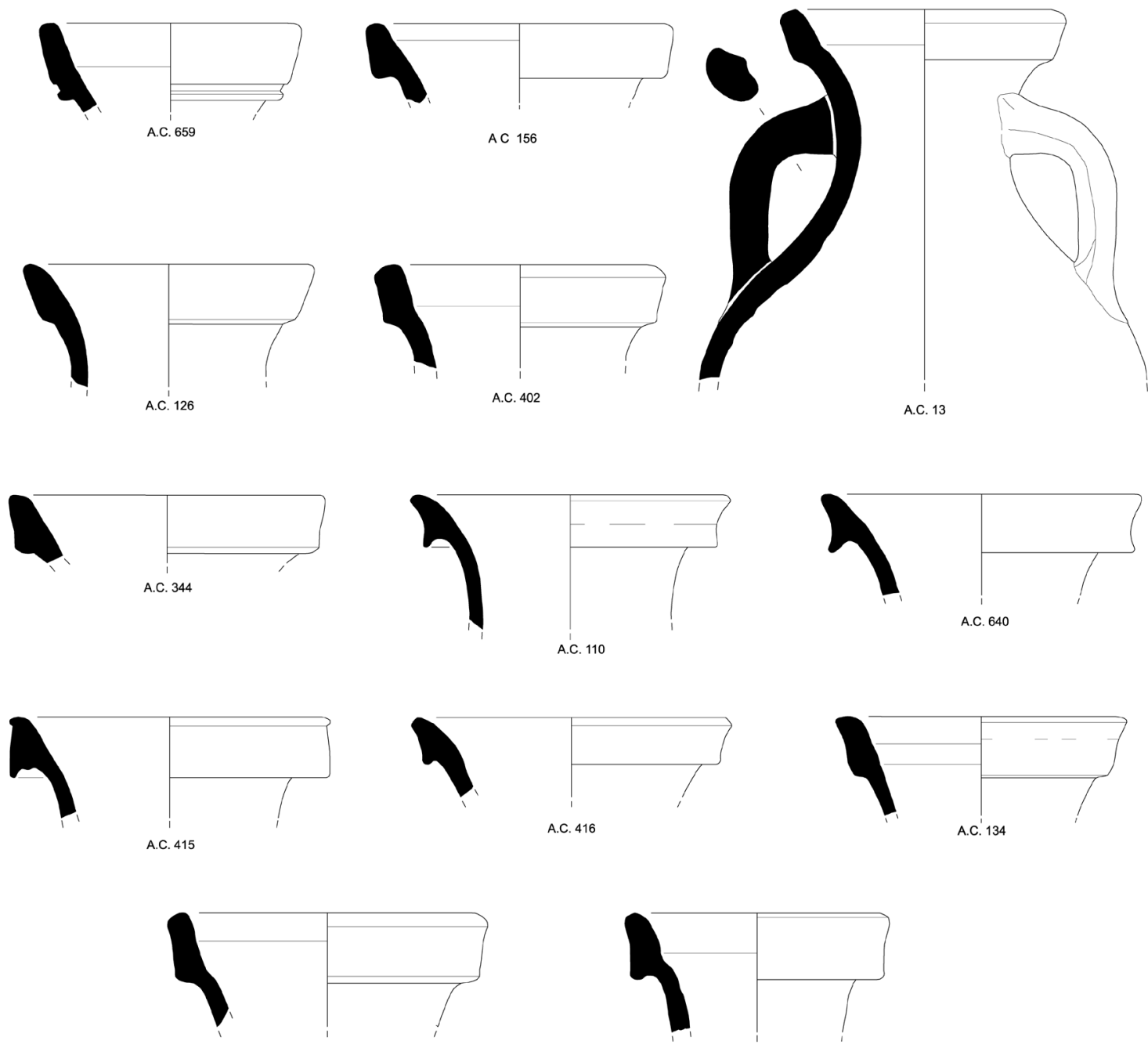

A.C. 645

A.C. 403

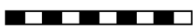

Figura 8. Ânforas da costa sudoeste da Ulterior/Bética. Mañá C2b: 439, 932, 788, 900, 106; Classe 67: 410, 345, 652, 659; “Ovóides gaditanas”: 156, 13, 126, 402, 344; Dressel 10 (?): 110, 640, 415, 416; Dressel 7 (?): 134, 645, 403. 
29\% das ânforas recebidas entre os finais da República/início do Principado (ver Figuras 5-6 e 8-10).

$\mathrm{O}$ arranque da sua produção situa-se, presentemente, nos momentos finais da República, coincidindo com o período terminal da produção dos tipos de ânforas anteriormente apresentados, e com os quais conviverão ainda alguns anos nos circuitos comerciais e no registo arqueológico. Assim, aproximadamente a partir de 40/30 a.C. surgem nas olarias localizadas sobretudo em torno à Baía de Cádis os tipos Dressel 7 a 11, ânforas com morfologias próprias e já totalmente romanizadas, que, embora se considere estarem inspiradas em formas tirrénicas e adriáticas, não constituem imitações directas ou derivações das ânforas itálicas. Os exemplares mais antigos conhecidos num centro produtor são os de Gallineras/Cerro de Los Mártires, em San Fernando (García Vargas, 1998). No actual estado do conhecimento, parece que num primeiro momento apenas se fabricaram ânforas dos tipos Dressel 7, 9 e 10, admitindo-se que as Dressel 9 e 10 são as formas que "descendem" das denominadas "ovóides gaditanas", enquanto que na constituição do tipo Dressel 7 parecem ter influído formas itálicas como as Dressel 1 e Lamboglia 2. Independentemente da provável ou hipotética "ascendência"/influência formal, a imagem de maior antiguidade destas três formas Dressel 9, 10 e 7 - é também a que transparece dos centros de consumo peninsulares e mediterrânicos (García Vargas, 1998; García Vargas, Almeida, González Cesteros, 2011, 258).

$\mathrm{Na}$ abordagem e estudo destes vários tipos, concretamente perante fragmentos de bordo ou de outras partes da ânfora, dada a dificuldade em atribuir individualmente os fragmentos aos vários tipos definidos por H. Dressel, pode afirmar-se que existem actualmente duas grandes tendências/vias possíveis: a primeira, considerá-los apenas como parte de um todo, classificando-os unicamente como "Dressel 7-11", à semelhança do que outros autores têm feito (Zevi, 1966; Beltrán Lloris, 1970; Peacock, Williams, 1986); a segunda, tentar, em função dos vários parâmetros e descritores morfológicos mais recentes, sintetizados e propostos nas fichas tipológicas compiladas no Laboratório Virtual Amphorae Ex Hispania 1 , sem esquecer, no entanto,

1 Cf. García Vargas, Bernal Casasola, 2016, para Dressel 7; García Vargas, Martín-Arroyo Sánchez, Lagóstena Barrios, 2016a, para Dressel 8; García Vargas, Martín-Arroyo Sánchez, Lagóstena Barrios, 2016b, para Dressel 9; García Vargas, Martín-Arroyo Sánchez, Lagóstena Barrios 2016c, outros trabalhos de "referência obrigatória" (García Vargas, 1998; Martin-Kilcher, 1994; Martin-Kilcher, 2001; Étienne, Mayet, 2002; Martin-Kilcher, 2003), propor uma classificação que se aproxime à proposta dos tipos de Dressel.

Deste modo, e apesar de tudo conscientes das dificuldades inerentes, é com alguma cautela e reservas que arriscamos uma classificação "mais fina" para os fragmentos recolhidos em Alto dos Cacos, tentando modestamente descortinar algo mais dentro dessa aparente homogeneidade formal. Não obstante, no que se refere à quantificação global, evitando a criação de inúmeras divisões baseadas em dúvidas ou situações dúbias resultantes da nossa observação, optámos por quantificá-los segundo o princípio anterior (ver Figuras 5 e 6).

Apesar das limitações tipológicas referidas, da observação dos perfis preservados dos fragmentos de bordo recolhidos em Alto dos Cacos, constatámos que apresentam maior nível de semelhança com os presentes nas formas 9, 10 e 7 da tabela de Dressel, as que actualmente se entendem como "sucessoras" das morfologias ovóides. Desse modo, não resulta difícil compreender as dificuldades ocasionalmente existentes na hora de determinar se alguns fragmentos pertencem aos primeiros ("ovóides gaditanas") ou aos segundos (Dressel 9,10 ou 7), e dentro destes qual exactamente... As afinidades formais entre ambos grupos de tipos e as dificuldades de identificação/classificação estão bem patentes nas diferentes abordagens e leituras que se têm vindo a realizar sobre o seu estudo (García Vargas, 1998; 2001; Martin-Kilcher, 2001; Ehmig, 2010; García Vargas, 2010; García Vargas, Sáez Romero, no prelo).

Em função das características morfológicas que podemos observar nos fragmentos de Alto dos Cacos e do seu confronto com a bibliografia de referência (cf. nota 1), consideramos que os nºs AC110, 640, 415, 416 (Figura 8) e 14 (Figura 9) se podem definir como Ovóides/Dressel 10 ou simplesmente como Dressel 10 (provavelmente mais este último tipo), que os $\mathrm{n}^{\circ} \mathrm{s}$ AC134, 645, 403 (Figura 8), 401, 179, 112 e 133 (Figura 10) podem pertencer a ânforas Dressel 7 - quiçá integráveis na variante A estabelecida por García Vargas - e os nºs AC660, 120, 405, 132, 277 (Figura 10), podem, por sua vez, ser adscritos ao tipo Dressel 9; finalmente, os fragmentos de cor-

para Dressel 10; García Vargas, Martín-Arroyo, Lagóstena Barrios, 2016d, para Dressel 11. 
po com asas AC151 e 157, e os fundos 158, 148, 106, 130 e 129, podem pertencer indistintamente a tipos ovóides ou aos tipos Dressel 7, 9 ou 10 (Figura 10).

Particularmente importante e interessante é o exemplar AC14, que se poderia definir como uma morfologia ovóide muito evoluída, praticamente uma Dressel 10B, segundo as propostas mais recentes (García Vargas, Martín-Arroyo, Lagóstena Barrios, 2016c). Conserva no colo entre ambas asas vestígios de uma inscrição pintada em tinta vermelha (rubrum) (10R 4/8), correspondendo a grande parte do um titulus pictus de difícil leitura e interpretação, para a qual pudemos contar com a inestimável ajuda de J. A. Zamora López, que poderá vir a realizar um estudo mais detalhado desta inscrição. Segundo este investigador, em observação preliminar que pôde realizar sobre a documentação gráfica, "alguno de los signos que pueden apreciarse y el propio ductus de otros podrían ser propios de la escritura neopúnica, lo que encajaría bien con el momento y el lugar asignables como origen del ánfora”. Esperamos que o aprofundamento do estudo permita extrair mais dados e alguma conclusão mais categórica.

Independentemente da adscrição particular dos fragmentos mencionados aos tipos de Dressel, o que objetivamente podemos extrair da análise e comparação transversal com outros fragmentos e conjuntos provenientes de alguns sítios de referência no actual território português, como Santarém (Arruda, Viegas, Bargão, 2005; Arruda, Viegas, 2014), o mais imediato e directamente relacionado, e o Monte dos Castelinhos (Pimenta, Henriques, 2014; Pimenta, 2015), ambos no Vale do Tejo, ou o Castelo da Lousa (Morais, 2010), Rocha da Mina (Mataloto, Williams, Roque, 2016) e Mesas do Castelinho (Parreira, 2008), todos já em território interior, e todos eles vinculados ao processo de conquista/consolidação e ordenamento do território, bem como com outros mais longínquos na Gália, como sejam Lyon e Saint-Romain-enGal (Desbat, Lemaítre, 2001), na Germania, como Petrisberg, Rödgen, Dangstetten ou Oberaden (Martin-Kilcher, 2001; Ehmig, 2010; González Cesteros, Tremmel, 2013; González Cesteros, 2014), ou mesmo em Cartago (Martin-Kilcher, 1993), bem como outros de meio subaquático como o Grand Congloué 3 (Liou, 2001), Cabrera IV/Moro Boti (Cerdà I Juan, 2000) ou SudPerduto 2 (Bernard, 2008), revelam que estamos perante um universo de contentores com evidentes afinidades e contornos tipológicos de imbricada e complexa definição, produzidos entre os últimos momentos da República e os inícios do Principado, concretamente entre $c .50 / 40$ e 20-10 a.C.

Em último lugar, gostaríamos ainda de fazer referência a dois fragmentos (não ilustrados devido à sua pequena dimensão) e de difícil classificação. Ambos apresentam bordo maciço, com perfil tendencialmente triangular e com um perfil ligeiramente virado para o exterior, aliado a um diâmetro aparente maior que o das Dressel 7, permitem considerar a possibilidade de pertencerem a ânforas do tipo Dressel 12. No caso de tal ser correcto, poder-se-ia tratar de exemplares com características atribuíveis a momentos do final da República ou ao período augustano (González Cesteros, Bernal Casasola, García Vargas, 2016).

Considera-se hoje em dia que a Dressel 12 possui um período de produção/comércio relativamente dilatado, compreendido entre os meados do século I a.C. e o terceiro quartel do século I d.C. Trata-se de um tipo hispânico claramente influenciado e

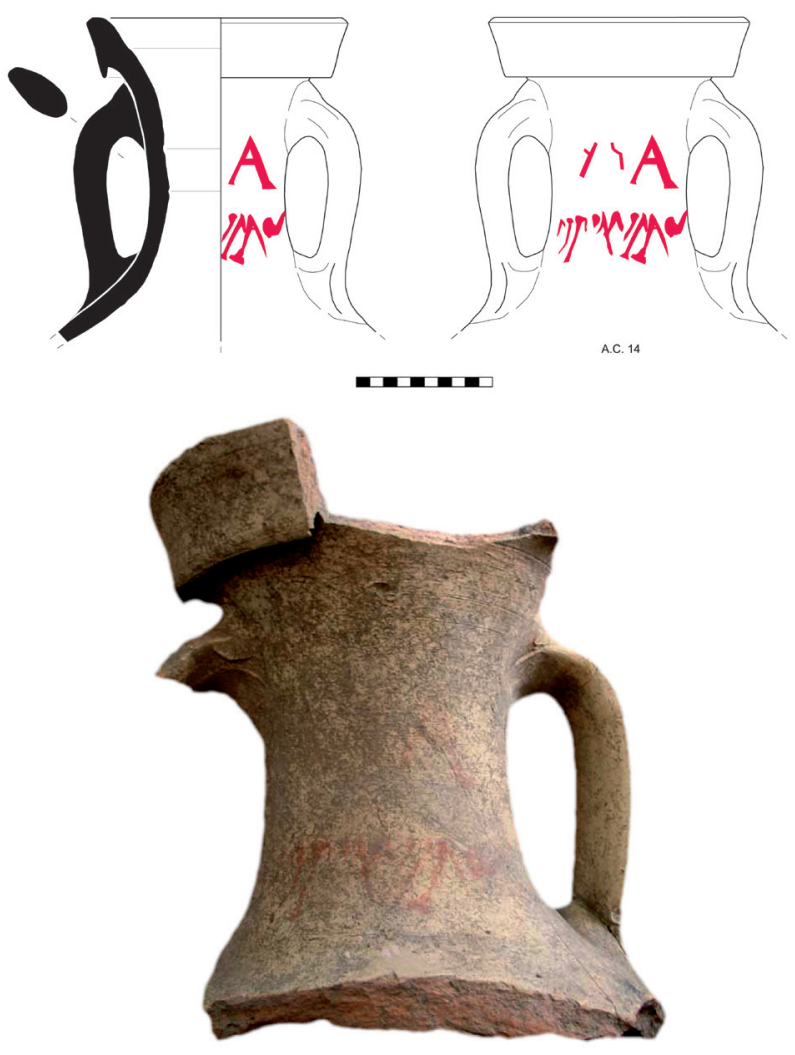

Figura 9. Ânfora da costa sudoeste da Ulterior/Bética. Dressel 10 com titulus pictus em rubrum. 

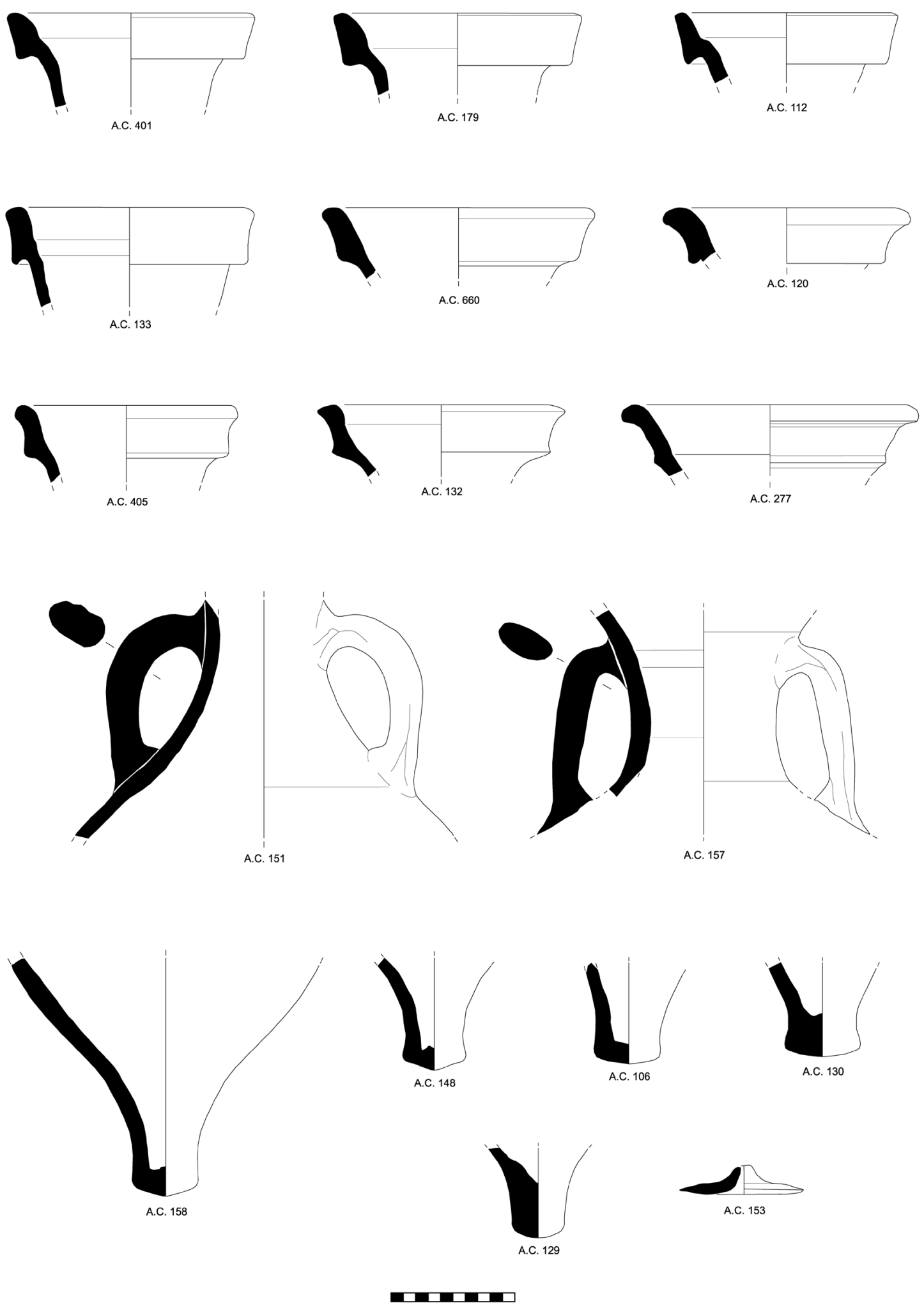

Figura 10. Ânforas da costa sudoeste da Ulterior/Bética. Dressel 7 (?): 401, 179, 112, 133; Dressel 9 (?): 660, 120, 405, 132, 277; Ovóides ou Dressel 7-11: 151, 157, 158, 148, 106, 130, 129; Opérculo: 153. 
“sucessor" do tipo Dressel 1C (García Vargas, 1998, 95-96; García Vargas, 2001, 63; González Cesteros, Bernal Casasola, García Vargas, 2016), particularmente o produzido na Hispania Ulterior desde o primeiro terço do I a.C., quer na costa gaditana (García Vargas, 1998; Sáez Romero, 2008), quer na costa meridional, concretamente na Baía de Algeciras (Bernal Casasola, Jiménez-Camino Álvarez, 2004) e em Málaga (García Vargas, González Cesteros, Almeida, no prelo; Mateo Corredor, 2016). No que se refere aos conteúdos, é sabido que se destinava a envasar preparados piscícolas, tal como se pode deduzir dos inúmeros tituli conhecidos (Beltrán Lloris, 1970; García Vargas, 2001, 64; González Cesteros, Bernal Casasola, García Vargas, 2016; especialmente González Cesteros, 2012).

Apesar de ser um tipo bastante bem conhecido, pode considerar-se um dos tipos minoritários de ânforas de salga de pescado da Ulterior/Bética. Embora se encontre com alguma frequência em sítios mediterrânicos, quer terrestres quer de naufrágios, a partir de meados do século I a.C. e frequentemente associados a ânforas ovóides hispânicas (García Vargas, 2001, 63), a quantidade e valores que representam dentro das amostras costuma ser bastante limitada. A sua difusão no território português não foge a esta regra, destacando, dir-se-ia, mais uma vez, pela negativa. De facto, são raros os sítios onde foram reconhecidas e publicadas ânforas deste tipo, referindo-se apenas Monte Mozinho (Soeiro, 1984), o acampamento militar da Lomba do Canho, em contexto do segundo quartel do século I a.C. (Fabião, 1989), Faro (Viegas, 2011), Castro Marim, em contexto datado entre 50-30 a.C. (Arruda et al., 2006, 167; Viegas, 2011, 493) e, claro está, a vizinha Santarém/Scallabis, integrando contextos de natureza e cronologia diversa, tanto de momentos Republicanos, como de época augusto-tiberiana, quer ainda de meados do século I d.C. De salientar os significativos 6\% que alcança o tipo Dressel 12 no computo geral das ânforas importadas de preparados piscícolas na cidade capital do conventus (Arruda, Viegas, Bargão, 2005, 286-287), bem como os $1,9 \%$ do total do NMI e os 2,2\% que representam do NMI do período republicano em Castro Marim, embora para a maioria se atribua uma origem no Vale do Guadalquivir (Viegas, 2011, 493-498).

\subsubsection{As ânforas do Vale do Guadalquivir}

A importação de produtos alimentares da área do Vale do Guadalquivir é o outro vértice em destaque no abastecimento ao sítio de Alto dos Cacos.
Por um lado, sobressai no conjunto tanto pela diversidade de tipos identificados como pela quantidade, com 154 fragmentos classificáveis, correspondendo a 72 indivíduos do total do NMI e a 38,3\% dos contentores, e a 66 indivíduos e praticamente idêntica representatividade $(38,8 \%)$ no que diz respeito unicamente ao consumo entre o final da República e primeiros momentos do Principado (ver Figuras 5-6). Os contentores e produtos provenientes de esta região alcançam uma notável "cota de mercado", muito próxima à da costa da Ulterior Bética, com a qual monopolizam o abastecimento.

Por outro lado, há que sublinhar a importância e significado de uma "família" particular de contentores: as ânforas ovóides do Vale do Guadalquivir. É obrigatório referir que quase metade (42\%) das ânforas provenientes desta região presente em Alto dos Cacos corresponde a tipos de morfologia ovóide de cronologia romana tardo-republicana (tipos Ovóide 1, 4, 5, 6 e 9), que, logo a partir dos primeiros passos dados na sua investigação (Fabião, 1989; Molina Vidal, 1995; Fabião, 2001; Molina Vidal, 2001), foram definidos e entendidos como resultantes do processo de criação de ânforas de características tipicamente ocidentais, de inspiração romana, sem a apropriação de características anfóricas da tradição púnica anterior, ocorrido paralela ou imediatamente posterior ao processo de "reprodução" dos modelos itálicos (Fabião, 1998b, 398).

A hipotética origem formal destes tipos desde cedo foi procurada e relacionada com as produções brindisinas e/ou outras da Itália meridional (Fabião, 1989, 66-67; Molina Vidal, 2001, 641; Fabião, 2001, 672) e a posterior investigação desenvolvida a partir de exemplares de Santarém (Almeida, 2008), não só fortaleceu a conexão com essas áreas, com alguns dos tipos concretos aí produzidos e com outros médio-adriáticos, como também forneceu nova imagem de maior complexidade e diversidade das produções ovóides béticas. Desse modo, a ligação formal entre as produções tardo-republicanas do sul da Hispania com as do sul da Itália, longe de ser um episódio ou fenómeno isolado, tornou-se uma tendência real, particularmente no Vale do Guadalquivir. A partir desse momento, o reconhecimento/identificação dos tipos ovóides aí produzidos passou a ser uma constante nos circuitos comerciais e principais sítios de consumo do Mediterrâneo ocidental e do Atlântico.

Nos últimos anos o seu repertório tem vindo a ser progressivamente sistematizado e o estado do 
seu conhecimento continuamente incrementado e actualizado (Fabião, 1989; Fabião, 2001; Almeida, 2008, Garcia Vargas, Almeida, González Cesteros, 2011; García Vargas, González Cesteros, Almeida, no prelo) e hoje, quase 30 anos passados desde a identificação da primeira morfologia, conhecem-se já 9 tipos, com diferentes graus de produção/ difusão, distinguindo-se um grupo de "formas consolidadas", com uma ampla exportação constatada arqueologicamente (Ovóides 1, 4, 5, 6 e 7), e outro de outras formas menos conhecidas e/ou menos produzidas/difundidas, que mantêm ainda um carácter de tipo "minoritário" (Ovóides 2, 3, 8 e 9).

Entre os vários tipos de ânforas ovóides produzidos no Vale Guadalquivir, constam em Alto dos Cacos as ânforas do tipo Ovóide 1, também denominadas Classe 67, Lomba do Canho 67 ou LC67, actualmente o melhor caracterizado, o mais conhecido e aparentemente um dos mais antigos dentro da "família" de contentores ovóides desta região; contudo, contrariando a imagem definida para o ocidente atlântico e território da futura província da Lusitânia, particularmente para a vizinha cidade de Santarém/Scallabis (Almeida, 2008), representa tão somente $1,1 \%$ do conjunto com 2 NMI.

Estas ânforas possuem bordo tendencialmente amendoado e com um anel/moldura na sua parte inferior marcando a transição para colo, que é curto e do qual arrancam duas asas pequenas com estrias. Embora conhecido na bibliografia arqueológica desde há muito tempo, apenas com o estudo de C. Fabião sobre as ânforas do acampamento romano da Lomba do Canho (Arganil) foram individualizadas como tipo (Fabião, 1989, 65-73). A consequente identificação de exemplares e paralelos noutros contextos e âmbitos, peninsulares e mediterrânicos, sofreu um notável impulso de forma quase imediata graças em grande medida aos trabalhos de J. Molina Vidal (1995; 1997), consolidando-se como tipo específico. $\mathrm{O}$ posterior estudo dos exemplares de Santarém (Almeida 2008, 70 ss) avançou uma possível origem formal em formas apulas Baldacci 1C (Baldacci, 1972), bem como noutros tipos médioadriáticos do Piceno, datados entre os finais do século II e 30 a.C. (Carré, Mattioli, 2003) e introduziu a designação de Tipo Ovóide 1, na lógica de uma sistematização de carácter regional, convertendo-se este tipo na ponta mais visível do iceberg (Almeida, 2008; Almeida, 2010).

Paradoxalmente, apesar de tratar-se do tipo ovóide do Guadalquivir que maior impacto parece ter tido em época tardo-republicana, são ainda inexistentes os vestígios directos relativos à sua produção (bem como à de outros tipos ovóides...). Não se conhece nenhum centro produtor e presentemente não se afigura provável que se possam localizar nas áreas conhecidas com grandes concentrações de olarias, implantadas ao longo do curso do rio, já que as mesmas apenas parece terem surgido aí a partir de época augustana ou tiberiana (García Vargas, 2001, 72; 2010a, 587; 2010b; Berni Millet, 2011, 92; García Vargas, Almeida, González Cesteros 2011, 242243; García Vargas, González Cesteros, Almeida, no prelo).

Um dos aspectos pendentes no estudo deste tipo, se assim se pode dizer, é o do seu conteúdo. Foi inicialmente avançada a proposta de se destinarem ao transporte de conteúdos piscícolas, (Fabião, 1989, 66-68), seguindo-se a de um carácter polivalente (Fabião, 2001, 673). Assim, se a produção em menor escala nas olarias da costa da Ulterior e a forma dos seus bordos incita a pensar num contentor para preparados piscícolas, para as produções do Guadalquivir, o azeite ou o vinho, mas sobretudo o primeiro, foram avançados como hipotéticos conteúdos, parecendo a proposta avançado de um conteúdo piscícola menos verossímil (cf. García Vargas, Almeida, González Cesteros, 2011, 214-216, esp. nota 15). A própria morfologia destas ânforas, de similitudes evidentes com as ânforas itálicas meridionais e médio-adriáticas, faz pensar no azeite, um produto abundante no vale do Guadalquivir, de cuja exportação esta ânfora poderia ter constituído um primeiro contentor (Almeida, 2008, 194-195, 287; García Vargas, Almeida, González Cesteros, 2011, 214).

No que concerne à sua cronologia, está compreendida entre o início do segundo quartel e o início do último quartel do século I a.C. (Fabião, 1989; 2001; Molina Vidal, 1995; 2001; Almeida, 2008; García Vargas, Almeida, González Cesteros, 2011; González Cesteros, Almeida, García Vargas, 2016), momento em que se observa o seu desaparecimento nos mercados receptores, pelo que alguns dos exemplares publicados de Santarém, de contextos datados do primeiro terço do século I d.C. (Almeida, 2008, 82), devem ser entendidos como material residual (García Vargas, González Cesteros, Almeida, no prelo).

O período de máxima produção/difusão situa-se no terceiro quartel da mesma centúria, tal como se pode deduzir da sua exportação na Península Ibérica, mas sobretudo mais além deste âmbito, 

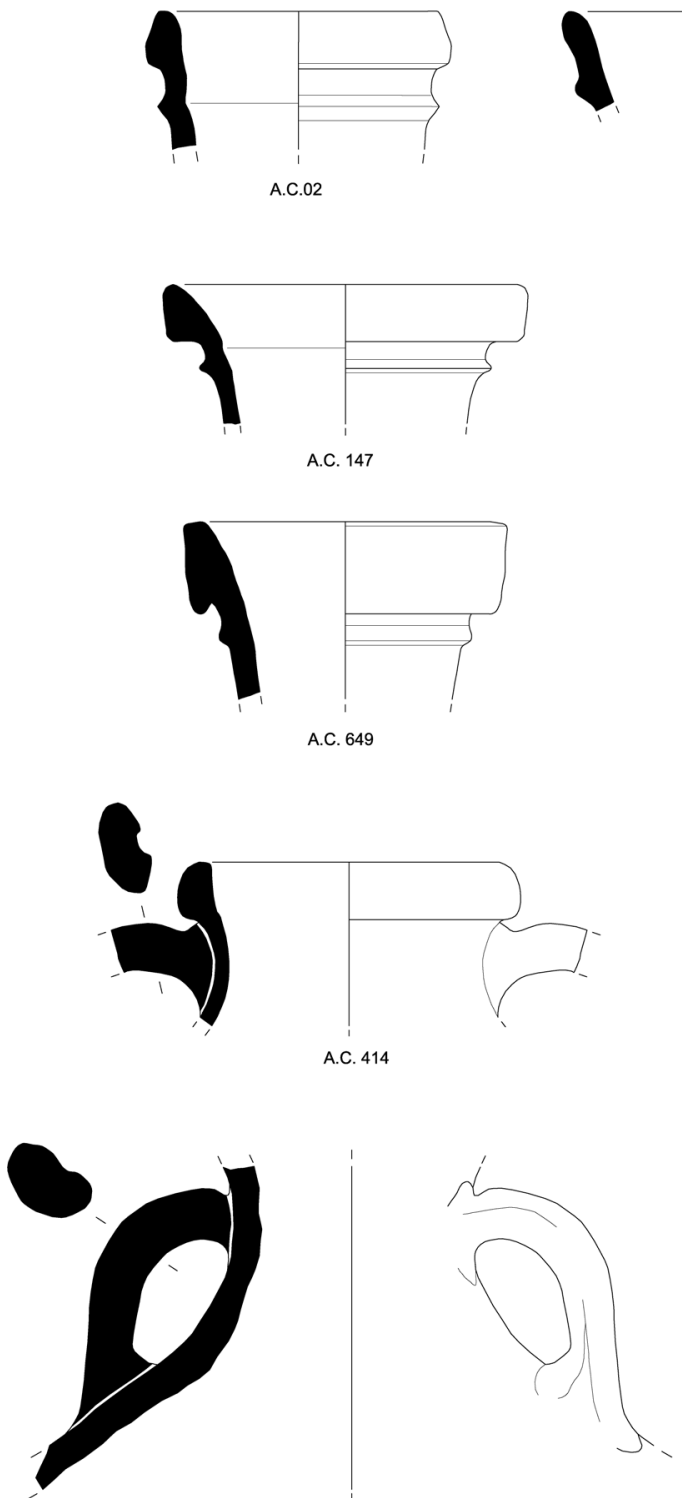

A.C. 165

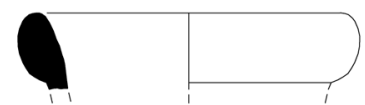

A.C. 433
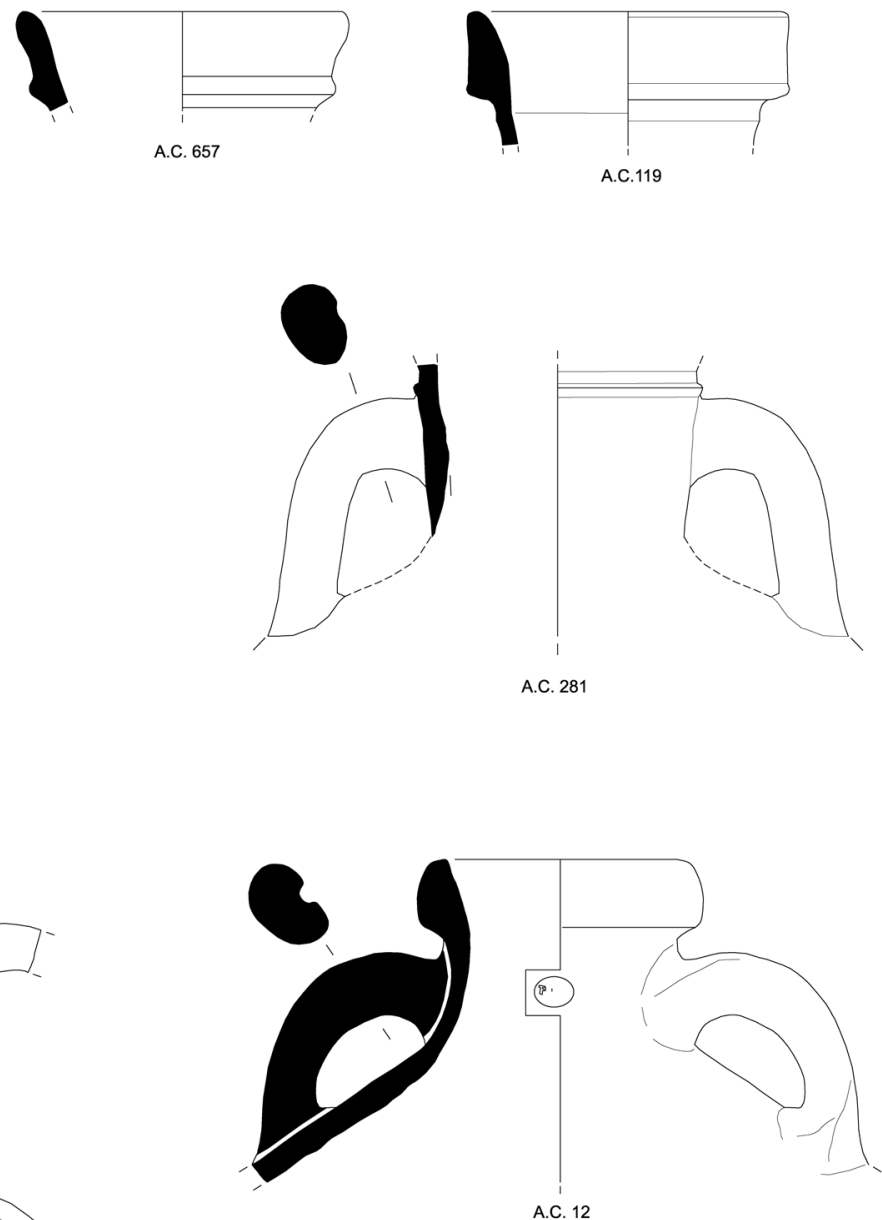

A.C. 12

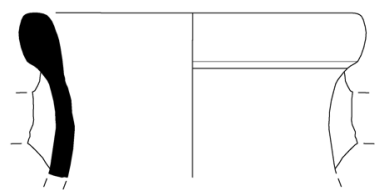

A.C. 408
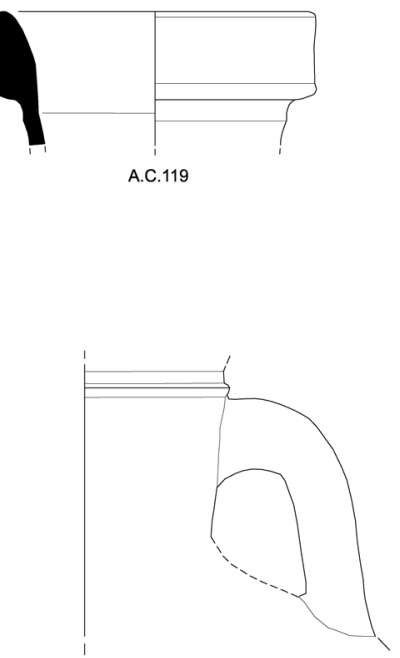

A.C. 281 
alcançando paragens terrestres do Mediterrâneo especialmente o francês (Fréjus), a Ligúria e Itália tirrénica (Albintimiglia e Ostia), inclusivamente penetrando por vias fluviais como o Garona (Vielle Toulouse) ou o Ródano (Lyon) - e estando presente em vários naufrágios - Grand-Congloué 3 (Liou, 2001), San Ferreol, Cartagena (Mas García, 1982) ou Rabat (Boube, 1979-1980) - que documentam de forma incontestável a sua circulação nos principais eixos comerciais desses momentos (Molina Vidal, 2001, 640; Almeida, 2008, 72-76; García Vargas, Almeida, González Cesteros, 2011, 216; González Cesteros, Almeida, García Vargas, 2016; García Vargas, González Cesteros, Almeida, no prelo).

Mas sem qualquer dúvida, o seu principal foco de distribuição e concentração (ou pelo menos de identificação...) é o cenário da fachada atlântica peninsular e respectivas áreas de penetração interior imediatas, onde destacam Castro Marim/ Baesuris (Arruda, 1996; Arruda et al., 2006; Viegas, 2011), Faro/Osonoba (Viegas, 2011), Mesas do Castelinho (Fabião, 2001; Parreira, 2009), Monte dos Castelinhos (Pimenta, Mendes, 2014; Pimenta, 2015), Santarém/Scallabis (Almeida, 2008), Lomba do Canho (Fabião, 1989), ou os castros de Vigo, Santa Tecla (Peña Santos, 1986) e Montealegre (González-Ruibal et al., 2007). O panorama traçado em trabalhos anteriores - que não se esgota com os locais enumerados e que não cabe aqui desenvolver exaustivamente (cf. Fabião, 2001; Almeida, 2008, 75-76 e Figura 17; Almeida, 2010, especialmente Figura 2) - tem-se visto incrementado com novos sítios, mas que em nada alteram o proposto; pelo contrário, as novas descobertas têm vindo a consolidar as leituras estabelecidas (García Vargas, Almeida, González Cesteros, 2011, 216-217 e 268-269, Figura 35).

A imagem actualmente disponível para o Ocidente confirma uma importante difusão/presença do tipo Ovóide 1 entre 60-20 a.C., da Ulterior ocidental ao quadrante noroeste da Citerior, com especial profusão da bacia do Guadiana à Gallaecia, em destinos com clara natureza militar ou em contextos militarizados, sem que sejam muitos os sítios que revelem importações deste tipo em número significativo (García Vargas, Almeida, González Cesteros, 2011, 217). Naturalmente, neste contexto, não surpreende que os sítios do Vale do Tejo sejam particularmente profícuos...

Manifestamente diferente é o caso do fragmento de bordo AC119 (Figura 11), a que já se fez uma breve referência noutro trabalho específico sobre as produções ovóides tardo-republicanas do Vale do Guadalquivir (García Vargas, Almeida, González Cesteros, 2011, 205-206). O seu bordo alto é subtriangular, com um pequeno ressalto em ambas extremidades do lábio, mais marcado no inferior, o que lhe confere um ligeiro aspecto moldurado; paralelamente, a parte inferior externa do lábio é plana e ligeiramente biselada, ao passo que a parte alta interna do bordo apresenta uma suave inflexão/carena. Por sua vez, o bordo assenta sobre um colo vertical.

O conjunto de características enumeradas e a pasta do fragmento que agora se estuda - esverdeada clara e com muito quartzo e quartzito rolado, que certifica uma proveniência da área do Baixo Guadalquivir - são em tudo idênticas às que ostentam os exemplares do recente tipo Ovóide 9, identificado, definido e caracterizado a partir de vários fragmentos recuperados na escavação dos muros de opus africanum do Patio de Banderas do Real Alcázar de Sevilla (García Vargas, 2012; García Vargas, Almeida, González Cesteros, 2011, 205-206). Mais uma vez, os paralelos apresentados para a sua possível origem formal foram encontrados nas produções meridionais itálicas, concretamente na variante $\mathrm{B}$ da forma VII de Apani (Palazzo, 1988, 112-113; Palazzo, 1989, 549 e 553; García Vargas, Almeida, González Cesteros, 2011, 205-206 e Fig. 9). Cronologicamente, a produção deste tipo enquadra-se entre 50-25 a.C., datação fornecida pelo seu contexto de proveniência.

A relevância deste exemplar em Alto dos Cacos reside no facto de representar um dos poucos casos actualmente identificados, senão mesmo o único, de ânforas deste tipo "minoritário" fora do seu âmbito produtivo imediato, em claro contexto de "exportação"; no caso de se confirmar igual classificação proposta para um exemplar do Castelo da Lousa (García Vargas, Almeida, González Cesteros, 2011, 206-207 e Fig. 9), erroneamente classificado como Dressel 12 (Morais, 2010, 214, Estampa XXXVI.82), seriam apenas estes dois os pontos no mapa da difusão além de Hispalis. É incontornável referir que, novamente, estamos perante dois sítios com evidentes conotações militares...

Igualmente representado na amostra de Alto dos Cacos está o tipo conhecido como Ovóide 5, com 6 fragmentos, que correspondem a 3 NMI e 1,6\% do conjunto e a $1,8 \%$ dos contentores hipoteticamente recebidos/consumidos entre os finais da República/ início do Principado (ver Figuras 5-6). Esta ânfora, 
inicialmente confundida e frequentemente "misturada” com fragmentos do tipo Ovóide 1, pelo facto de apresentar também um típico anel/moldura no colo (veja-se como exemplo García Vargas, Bernal Casasola, 2008), foi definida e individualizada como tipo próprio a partir do estudo de exemplares da vizinha cidade de Santarém (Almeida, 2008, 126-134). A partir desse momento passou a integrar o repertório das produções regionais do Vale do Guadalquivir (Almeida 2010; García Vargas, Almeida, González Cesteros, 2011; García Vargas, 2012;) e tem vindo a ser recorrentemente identificada em sítios do Mediterrâneo ocidental, especialmente na Península Ibérica; podemos mesmo considerar que perdeu actualmente a sua condição de "tipo minoritário", tendo-se convertido noutra "presença habitual" nos contextos grosso modo atribuíveis ao segundo terço do século I a.C.

Os fragmentos AC147 e 649 possuem bordos com as peculiares características que apresentam os deste tipo: secção subtriangular, e menos frequentemente subrectangular, com parte externa ligeiramente descaída, assumindo quase a forma de uma aba, ocasionalmente mais pronunciada, ou menos descaída, com tendência levemente amendoada. A estes bocais associa-se um colo rectilíneo, tendendo a um perfil mais cilíndrico, com uma moldura muito marcada localizada na sua parte terminal superior, antes da ligação com a boca, embora claramente separada desta, tal como nos demonstra o fragmento AC281 (Figura 11). Também neste fragmento se podem observar ainda as típicas asas deste tipo, subcirculares com um sulco dorsal pouco pronunciado, ao contrário das asas da maioria dos restantes tipos ovóides, onde este é profundo e bem marcado (Almeida, 2008, 126; García Vargas, Almeida, González Cesteros 2011, 225-228; García Vargas, Almeida, González Cesteros, 2016b; García Vargas, González Cesteros, Almeida, no prelo).

Tal como para os tipos anteriores, não existe evidência directa de lugares de produção, mas a sua petrografia peculiar, com uma matriz coincidente com a das cerâmicas comuns regionais da área do Baixo Guadalquivir, e também com a das posteriores ânforas Dressel 28 (por vezes confundida com pastas da costa bética...), permite constatar que será essa a área de proveniência da maior parte dos exemplares deste tipo (García Vargas, Almeida, González Cesteros 2011, 226; García Vargas, Almeida, González Cesteros 2016b). Não obstante, é sabido que, tal como para o tipo Ovóide 1, parece existir uma produção minoritária na costa mediterrânica da Ulterior, concretamente em Torre del Mar (Málaga) (Arteaga Matute, 1985; García Vargas, Almeida, González Cesteros, 2016b). No que diz respeito ao seu possível conteúdo, dada a sua condição de tipo ovóide, propõe-se apenas um conteúdo oleícola ou de produtos da uva, o género de produtos que costumam estar relacionados com estas morfologias, como acontece com as produções itálicas e norte-africanas, como anteriormente já se referiu.

Quanto à sua cronologia de produção e âmbitos de difusão, os dados actualmente disponíveis sugerem uma estreita relação com a dos tipos Ovóide 1 e 4, particularmente o primeiro. Aceita-se um período de produção/circulação entre 60-20/15 a.C., verificável a partir de contextos de "trânsito" e redistribuição - como os do achado subaquático de Ceuta (Bernal Casasola, 2007), como pode ser talvez entendido o da Colónia San Jordi, Maiorca (Guerrero Ayuso, 1987), e seguramente os dos naufrágios de Illes Formigues I e Cala Bona I, nestes últimos viajando com outros tipos ovóides do Guadalquivir, designadamente o Tipo 4, ovóides da costa gaditana e da Tarraconense (Martín Menéndez, 2008), com prováveis destinos na costa atlântica de Marrocos, nas Baleares/Mediterrâneo central e/ ou setentrional, respectivamente; a presença de um bordo deste tipo no acampamento de Dangstetten (Ehmig, 2010, Tafel 15, 449-058-1; García Vargas, Almeida, González Cesteros, 2011, 228) é prova da sua "exportação" para os mercados militares da fronteira germânica, embora a sua quantidade e a cronologia do sítio apontem para um momento final do tipo.

No caso da fachada ocidental atlântica e do actual território português, também o quadro de distribuição é semelhante ao dos tipos ovóides de maior êxito, com vários sítios já incontornáveis. Assim, desde o Guadiana para ocidente e para Norte, é conhecida a sua presença em Castro Marim (Viegas, 2011), Castelinho dos Mouros, no baixo Guadiana (Gradim et al., 2014), Mesas do Castelinho (Fabião, 2001; Parreira, 2009), Monte dos Castelinhos (Pimenta, Henriques, Mendes, 2012; Pimenta, Mendes, 2014), Santarém/Scallabis (Almeida, 2008) e Castro de Montealegre, em paragens mais longínquas, já na actual Galiza (González-Ruibal et al., 2007).

O segundo tipo ovóide melhor representado é o conhecido como Ovóide 6 (Almeida, 2008, 145). Encontra-se representado por 6 fragmentos, equivalentes a 5 NMI, e que correspondem a 7\% das ân- 
foras recebidas do Vale do Guadalquivir e a 2,7\% do total do conjunto. As ânforas denominadas como Ovóide 6 trata-se das primeiras produções no vale do Guadalquivir que podem considerar-se como um contentor seguramente destinado ao transporte de azeite (García Vargas, Almeida, González Cesteros, 2011, 228). É claro neste tipo a influência que os modelos das ânforas olearias tardo-republicanas do sul da Península Itálica tiveram na sua criação, podendo mesmo ver-se nas primeiras Ovóide 6 tentativas de imitação, mais ou menos felizes, das ânfora olearias da Apúlia (García Vargas, Almeida, González Cesteros, 2011, 228 ss; García Vargas, Almeida, González Cesteros, 2016c).

A individualização deste modelo das formas iniciais de Dressel 20 teve origem na proposta de tipologia de Peacock e Williams (1986), que individualizaram na sua Classe 24 todos os contentores oleários anteriores à aparição das ânforas Dressel 20. Pouco tempo depois, a propósito do estudo das ânforas do acampamento romano da Lomba do Canho, Arganil, Carlos Fabião (1989, 73-74), seguindo dita tipologia, classificou como Classe 24 várias destas ânforas e dotou-as de uma cronologia inequivocamente tardo-republicana. Nesse estudo sublinhou que estas ânforas, apesar de terem características comuns com as suas sucessoras Oberaden 83 , as olearias de época augustana, deviam ser tratadas à parte (Fabião, 1989, 73-74), já que a sua unificação podia mascarar o início e antiguidade das exportações béticas de azeite (Fabião, 2001, 669). Já em época mais recente, no estudo do conjunto de ânforas do Vale do Guadalquivir identificadas em Scallabis/Santarém, avançou-se a denominação desta forma como Ovóide 6, integrada na lógica da caracterização de tipos relacionados, dentro de uma sequência regional, neste caso aferida através da sólida evidência de um sítio de consumo (Almeida, 2008, 145-147).

Em termos morfo-tipológicos é relativamente difícil dar uma imagem standard, uma descrição satisfatória e completamente sólida do tipo, dado que se trata de um contentor com relativa heterogeneidade formal, e que tem determinados aspectos comuns com outros tipos ovóides, o que dificulta a sua identificação quando analisados separadamente; contudo, é único quando ditos elementos se encontram conjugados. As ânforas do tipo Ovóide 6 do Guadalquivir caracterizam-se por um corpo com morfologia ovóide e com uma largura semelhante ao da posterior Oberaden 83. Os bordos podem apresentar-se de várias formas, mas costumam apresentar um perfil ligeiramente aberto, com lábios de tendência arredondada, ou mesmo mais subrectangulares, mas sempre engrossados no exterior. O colo é curto, cilíndrico ou de tendência recta, ligando-se de forma suave com o corpo. As asas são curtas, com secção ovalada e com uma característica depressão longitudinal, também típica das ânforas Ovóide 4 e Haltern 70, mas que está totalmente ausente nas Oberaden 83 e nas Haltern 71, os tipos posteriores ao Ovóide 6 e anteriores à Dressel 20. Os fundos podem variar bastante, ainda que na maioria dos casos sejam maciços e de perfil troncocónico (Almeida, 2008; García Vargas, Almeida, González Cesteros, 2011, 234-235; 2016c; García Vargas, González Cesteros, Almeida, no prelo).

Os fragmentos recolhidos em Alto dos Cacos (Figura 11: AC414, 12 e 408), apresentam e conjugam os vários detalhes morfológicos que se acabaram de enumerar (bordo, colo, asas), facto que nos permite afirmar categoricamente que estamos ante ânforas do tipo Ovóide 6. O fragmento AC12 apresenta ainda a particularidade de possuir uma marca impressa no colo - recentemente publicada (Fabião et al., 2016, 73-74) - numa cartela oval, de que apenas se consegue ler TE[---]?. Trata-se aparentemente de uma marca desconhecida, cujo interesse radica não só no facto de tratar-se de uma marca antiga, mas também por estar realizada no colo, fenómeno que não é comum nas produções do Vale do Guadalquivir; nas manifestações epigráficas mais antigas conhecidas para esta região, realizadas sobre as ânforas olearias augustanas (sobretudo Haltern 71) nos anos imediatamente anteriores e posteriores à mudança da Era, apenas se conhecem exemplares com marca no bordo ou na base da asa (Berni Millet, 2008, 81-82).

No que compreende o início da produção/difusão do tipo Ovóide 6, a documentação arqueológica compilada em diversos contextos de consumo, especialmente na Península Ibérica e na Gália, parece apontar para o segundo terço do século I a.C., já que estão presentes em contextos iniciais da cidade de Lyon, como o dito Santuário de Cybele (Lemaître, Desbat, Maza, 1998; Desbat, Lemaître, 2001), mas estão comprovadamente ausentes dos contextos iniciais da fronteira germânica, como Neuss (González Cesteros, 2014, 122-125; González Cesteros, Berni Millet, no prelo), Dangstetten (Ehmig, 2010), Rödgen (Schönberger, Simons, 1976), ou na primeira fase do Kops Plateau de Nimega (Almeida et 
al., 2014; González Cesteros, Almeida, 2016); em todos eles está presente única e exclusivamente a forma, ainda ovóide, Oberaden 83.

Nos últimos anos tem vindo a multiplicar-se a identificação de ânforas do tipo Ovóide 6, alterando de forma contundente o anterior mapa da sua distribuição (Almeida, 2008, 147). Documenta-se actualmente uma forte distribuição a nível peninsular e extra peninsular (García Vargas, Almeida, González Cesteros, 2011, 234), com a sua presença atestada no sudeste francês chegando a lugares como Narbona, a região lionesa e mesmo a Suíça, onde se regista um exemplar em níveis anteriores à fundação da Colónia de Augusta Raurica (Martin-Kilcher, 1999). Para o extremo ocidente da Ulterior, importa referir a sua presença no acampamento da Lomba do Canho (Fabião, 1989), em Castro Marim e Faro (Viegas, 2011), Mesas do Castelinho (Parreira, 2009), bem como alguns exemplares no Castelo da Lousa (Morais, 2010; García Vargas, Almeida, González Cesteros, 2011, 230); por outra parte, no Vale do Tejo, onde, a par do Alto dos Cacos, são conhecidos vários exemplares de Santarém, em contextos do terceiro quartel do século I a.C. (Almeida, 2008; Almeida, 2010), bem como os recentemente publicados de Monte dos Castelinhos, Vila Franca de Xira, onde foram identificados diversos exemplares de Ovóide 6, em contextos estratigráficos e arquitectónicos bem definidos, da segunda metade do século I a.C. (50/30 a.C.) (Pimenta, 2015).

Todavia no que às ânforas de azeite do Vale do Guadalquivir se refere, alguns fragmentos apresentam-se de difícil classificação, podendo pertencer a dois tipos distintos: ao referido tipo Ovóide 6, ou já ao tipo plenamente augustano, conhecido como Oberaden 83 (ou Ovóide 7). Dizemos "podem" porque, de facto, a atribuição dos fragmentos de bordo AC433, 407 e 127 (Figura 11) ao tipo Oberaden 83 não é de todo segura, embora seja a classificação mais provável dadas as suas características morfológicas. A importância que detêm no conjunto das importações/consumo de Alto dos Cacos é relativamente significativa. Os seus $8 \mathrm{NMI}$ correspondem a c. de $11 \%$ das ânforas do Vale do Guadalquivir, a 5\% das ânforas da Bética, a 4,3\% do NMI total e a $c$. de $5 \%$ das ânforas recebidas entre os finais da República/início do Principado (Figuras 5-6).

As principais características morfológicas da ânfora Ovóide 7 (=Oberaden 83) consistem num corpo de morfologia tendencialmente ovóide - embora tenha perdido já o seu carácter puro, pois não se verifica a típica proporção da metade superior com a inferior, em que a primeira apresenta o diâmetro máximo do contentor - num bocal arredondado ao exterior, pouco espessado e quase "amendoado", e com uma disposição a apresentar a parede interior recta ou uma ligeira curvatura, fruto de um colo mais retilíneo e de maior longitude. As asas apresentam-se ligeiramente espessadas e com uma secção tendencialmente subcircular ou ovalada, sem sulco dorsal (Martin-Kilcher, 1994; Berni Millet, 1998; García Vargas, Almeida, González Cesteros, 2012; González Cesteros, García Vargas, Almeida, 2016). Assim, é tendo por base estes atributos que entendemos que devemos classificar os fragmentos AC433, 407 e 127 (Figura 11).

Foi no acampamento militar epónimo da fronteira germana que o tipo Oberaden 83 foi identificado, sendo automaticamente enquadrado em cronologias augustanas (Loeschke, 1909). Posteriormente, foi a partir da grande quantidade de achados em Augst, quando se realizou a primeira sistematização de fundo sobre exemplares fragmentários (Martin-Kilcher, 1987), caracterizando-se e estabelecendo-se uma sequência morfológica para o período compreendido entre os reinados de Augusto e Tibério, enlaçando com outra morfologia afim, a Haltern 71, precedendo ambas a forma Dressel 20.

Está actualmente aceite que a Ovóide 7 (=Oberaden 83) surgiu no início da segunda década antes do final do século I a.C. e que terá tido uma curta mas intensa produção/difusão, sendo "substituída" pela morfologia mais cilíndrica conhecida como Haltern 71 a partir da mudança da Era, ou nos anos imediatamente posteriores. Assim, com maior incidência a partir de 15 a.C. e em pleno principado de Augusto, o quadro de difusão do contentor Oberaden 83 vai ver-se enormemente ampliado, quando comparado com o do tipo Ovóide 6, particularmente pelo cenário de conquista na Germania, sendo omnipresentes quer em sítios militares germanos - Köln, Mainz, Nijmegen, Zurique, Novaesium, Xanten, Augst, Dangstetten, Colónia (González Cesteros, 2014) - quer em outros lugares ao longo da Gália e do eixo fluvial definido pelos rios Ródano e Reno Lyon, La Muette (Desbat, Lemaître, 2001) ou depósito de La Favoritte (Becker et al., 1986), Saint-Roman-en-Gal (Desbat, Martin-Kilcher, 1989; Desbat, Lemaître, 2001) (para uma discussão e atualização do tipo cf. García Vargas, Almeida, González Cesteros, 2011 e González Cesteros, García Vargas, Almeida, 2016). Também nos naufrágios atribuíveis 
ao mesmo período é verificável que é este o tipo em circulação nas duas últimas décadas do século I a.C./ princípios do I d.C., tal como se constata nos casos de Chrétienne H (Liou, 2001, Lám.XI, 2) ou Capo Graziano (Cavalier, 1985, p.92-93; Liou, 2001, Lám XI, 3). O ocidente atlântico não é exceção a esta difusão, encontrando-se o tipo Ovóide 7 (=Oberaden 83) representado em praticamente todos os sítios com ocupações desta cronologia, particularmente sítios relacionados com o processo tardio da conquista romana do território português, importantes centros urbanos ou fundações coloniais realizadas ou atribuídas ao primeiro principado. As principais concentrações conhecidas são em Lisboa, sobretudo no teatro romano (Filipe, 2015) e em Santarém (Almeida, 2008), ambas no Vale do Tejo (Almeida, 2008), mas estão igualmente bem atestados nos principais sítios urbanos do litoral algarvio, como é o caso de Monte Molião (Viegas, Arruda, 2013; Arruda, Viegas, 2016), Faro ou Castro Marim (Viegas, 2011).

Após a apresentação/discussão dos tipos supra, centramo-nos agora sobre o tipo conhecido como Ovóide 4 (Almeida, 2008; García Vargas, Almeida, González Cesteros, 2011; García Vargas, Almeida, González Cesteros, 2016a), que é, sem dúvida, o tipo ovóide melhor representado e uma das ânforas mais frequentes na amostra de Alto dos Cacos. Foi possível identificar 19 fragmentos, correspondentes a idêntico NMI, que, por sua vez, representam a proximadamente $1 / 4$ parte das ânforas recebidas do Vale do Guadalquivir (26,3\%), 10\% do total do conjunto e $11 \%$ das importações compreendidas entre os finais da República e o início do Principado (Figuras 5-6); valores bastante significativos e superiores ao habitual.

O tipo Ovóide 4 é um dos mais antigos tipos ovóides do Guadalquivir e o que mais discussão e interesse tem suscitado nas últimas duas décadas, em virtude da sua inegável parecença morfológica e aparente relação directa com a bem conhecida ânfora Haltern 70, amplamente distribuída em época imperial, que à luz das últimas propostas se tem vindo a considerar a sua "sucessora imediata" (Almeida, 2008, 100-104; García Vargas, Almeida, González Cesteros, 2011, 217-225; García Vargas, Almeida, González Cesteros 2016a); de facto, é justamente na existência de vários elementos e detalhes morfológicos comuns (embora diferenciáveis sobretudo por critérios de ordem métrica) que radica, em grande medida, a dificuldade no seu correcto reconhecimento/identificação e alguma "resistência” oferecida pelos investigadores actuais em aceitar a sua individualização como tipo próprio e mais antigo, considerando-o como uma "variante mais pequena" - na senda de Peacock e Williams, quando o consideraram como Haltern 70 "unusually small variant” (Peacock, Williams, 1986, 115-116) - ou apenas como uma "etapa morfológica" da Haltern 70 (Morais, 2010, 188-189; Berni Millet, 2011, 8488; Carreras Monfort, Berni Millet, 2016).

Não obstante a problemática e discussão envolvida, e sem estar respondido de forma taxativa se correspondem as duas formas/tipos relacionados que se sucedem no tempo - primeiro a Ovóide 4, depois a Haltern 70 - ou se terão surgido de forma (mais ou menos ) contemporânea, em torno a 7060 a.C. - dado que, como tradicionalmente se assumiu, a Haltern 70 teria surgido nessa data tal como o demonstrava a sua (suposta) presença no naufrágio de La Madrague de Giens (Tchernia, 1990, 296) - podendo ambos tipos ter convivido até ao desaparecimento do primeiro no início do Principado. O certo é que a evidência disponível parece apontar, com considerável solidez, para a primeira leitura. De facto, da análise atenta e exaustiva de um grande número de exemplares e respectivos contextos tardo-republicanos do Ocidente mediterrânico, particularmente de França, Espanha e Portugal, apesar de não possuírem todos a mesma precisão cronológica ${ }^{2}$, é possível constatar que “(...) en los contextos de mayor antigüedad, con fechas próximas a la del pecio de La Madrague de Giens y en las dos décadas posteriores, únicamente se documentan ánforas de morfología ovoide,en este caso del tipo Ovoide 4, y siempre con carácter minoritário (...)" (García Vargas, Almeida, González Cesteros, 2011, 219). Assim, à exceção da suposta Haltern 70 presente em La

2 Destacamos naufrágios como Grand-Congloué 3 (Liou, 2001), Titan (Benoit, 1956), Portopí (Cerdá i Juan, 2000), Cap Gros “C” (Gauthier, Joncheray, 1993), Cala Bona I e Illes Formigues I (Martín Menéndez, 2008), e contextos terrestres grosso modo contemporâneos, como o Horizonte 1 do santuário de Cybèle (Lemaître, Desbat, Maza, 1998), o cardo D de Ampúrias (Aquilué et al., 2004), o acampamento da Lomba do Canho (Fabião, 1989), Scallabis/Santarém (Almeida, 2008), Mesas do Castelinho (Parreira, 2009), Castro Marim (Viegas, 2011), Cueva de las Peñas Blancas (Lillo Carpio, 1986) ou Corts Valencianes, Valência (Pascual Berlanga, Ribera i Lacomba, 2001).

Para um levantamento mais detalhado e debate aprofundado veja-se especialmente Almeida, 2008, 103-104 e García Vargas, Almeida, González Cesteros, 2011, 219-225. 
Madrague de Giens (de que só existem referências textuais, sem nunca se ter publicado foto ou desenho...), não se conhece actualmente em nenhum contexto arqueológico do segundo terço do século I a.C. uma ânfora Haltern 70 "típica" (Almeida, 2008, 100; García Vargas, Almeida, González Cesteros, 2011, 219). Simultaneamente, tal facto leva a questionar se o exemplar presente na carga desse naufrágio da costa francesa, argumento de base e frágil pilar para a cronologia do início da produção/exportação do tipo Haltern 70 - com outras implicações e repercussões no da produção anfórica do Vale do Guadalquivir - corresponde a uma ânfora Ovóide 4 (García Vargas, Almeida, González Cesteros, 2011, 219) ou a outro tipo ovóide similar, nomeadamente não hispânico, tal como outros autores já alertaram (Étienne, Mayet, 2000, 90).

Em função do exposto, o período de produção/ exportação do tipo Ovóide 4 estaria compreendido entre o final do primeiro terço do século I a.C. e o início do Principado (c. $80 / 70$ - 30 a.C.), tal como outros tipos ovóides, e particularmente entre as décadas de 30-20 a.C. conviveria já com a etapa "inicial" do tipo Haltern 70, não supondo o aparecimento deste último o desaparecimento imediato do tipo anterior (Almeida, 2008, 101; García Vargas, Almeida, González Cesteros 2011, 223-224; García Vargas, Almeida, González Cesteros, 2016a).

Tal como para outros tipos ovóides do Vale do Guadalquivir, a evidência directa da sua produção é praticamente nula, limitando-se actualmente à Calle González Parejo, nº 19B de Carmona (Carmo), onde, não obstante, a maior parte dos exemplares são aparentemente residuais em contextos entre 20 a.C. a mudança da Era (García Vargas, 2012); contudo, estes dados, aliados às características de vários outros, apontam para uma produção em torno à área da metade inferior do Vale do Guadalquivir, entre Ilipa (Alcalá del Río), Carmo (Carmona) e Hispalis (Sevilla).

Finalmente, quanto ao seu provável conteúdo, o crescimento percentual do tipo Ovóide 4 no registo arqueológico em detrimento da diminuição progressiva dos contentores vinícolas itálicos ao longo do terceiro quartel do século I a.C. (Arruda, Almeida, 1999; Arruda, Almeida, 2001; Almeida, 2008, 286), a proximidade morfológica e uma defendida filiação formal entre a Ovóide 4 e a Haltern 70 , bem como a constatação de vários exemplares do tipo ovóide resinados no seu interior - designadamente todos os recuperados no naufrágio de Illes
Formigues 1 (Martín Menéndez, 2008, 106-107) são argumentos que levam a supor conteúdos vitivinícolas; no entanto, perante a ausência de análises de resíduos e/ou de inscrições pintadas, outros são igualmente possíveis, inclusivamente a hipótese de se tratar de um contentor multiusos (Fabião, 2001; Almeida, 2008; García Vargas, Almeida, González Cesteros 2011, 224; García Vargas, Almeida, González Cesteros, 2016a).

Debruçando-nos agora diretamente sobre os fragmentos de Alto dos Cacos alvo do presente estudo, verificamos que existem dois grandes grupos de exemplares: um primeiro, composto por fragmentos de maior dimensão que apresentam uma ou várias características formais em associação que permitem classificá-los claramente como Ovóide 4; um segundo, composto sobretudo por fragmentos de bordo, sem colo, em que a classificação é mais duvidosa e onde estão bem patentes as limitações já referidas por vários autores.

Dos primeiros dão exemplo os fragmentos AC406, 107, 111, 121, 44, 770 (Figura 12). Na sua maioria são bordos amplos, ligeiramente abertos e curtos, com alturas compreendidas entre os 3 e os $4 \mathrm{~cm}$, com perfil subtriangular ou rectangular em forma de "colarinho"; o colo é bitroncocónico e também curto, inferior a $10 \mathrm{~cm}$, de donde arrancam as asas, igualmente curtas, com um frequente sulco longitudinal, e descrevem uma abertura em quarto de círculo relativamente ampla. A forma/altura do bordo e a altura do colo/asas, os melhores elementos de diagnóstico ao nível de material fragmentário, não só estão perfeitamente de acordo com as propostas para o tipo Ovóide 4 (Almeida, 2008, 98ss, especialmente Figs. 28-29; García Vargas, Almeida, González Cesteros, 2011, 219ss, especialmente Figs. 17-19), como a conjugação de ambos permite confirmar que estamos ante ânforas ovóides deste tipo.

Diferente é caso dos segundos, ilustrados pelos fragmentos AC766, 426 e 207. Dada a sua reduzida dimensão e estando ausentes outros atributos (colo, asas, etc.), a sua classificação como Ovóide 4 foi aferida exclusivamente com base à altura do lábio $(<=4 \mathrm{~cm})$, complementada com a semelhança existente entre o desenho/forma geral dos mesmos e o de outros paralelos conhecidos, particularmente exemplares estudados na vizinha cidade de Santarém/Scallabis (Almeida, 2008, 98ss). Não obstante, tal como em outros ocasiões se advertiu, embora a maioria das peças conhecidas apresente bordos que não ultrapassam os $4 \mathrm{~cm}$ de altura, este critério 
não é taxativo dado que existe uma certa heterogeneidade a este nível (Almeida, 2008, 102; García Vargas, Almeida, González Cesteros, 2011, 219).

$\mathrm{O}$ número de prováveis indivíduos deste tipo identificados em Alto dos Cacos é muito significativo (19 NMI=10\% NMI), apenas comparável com o valor contabilizado para Santarém, e tal como se referiu, em número superior ao conhecido para outros sítios do território português, que são poucos comparativamente com o número de sítios com outros tipos ovóides (cf. Almeida, 2010, Figura 2); contudo, há que ter presente e relativizar dito número de sítios/achados, que deve ser entendido como um reflexo inerente e proporcional às dificuldades de identificação do tipo Ovóide 4. Ainda assim, está registada a sua recepção no actual norte de Portugal e Galiza, antigo noroeste da Tarraconense, no castro de Santa Trega/Santa Tecla (Beltrán Lloris, 2001; Morais, 2004a, 36), talvez na citânia de Sanfins (García Vargas, Almeida, González Cesteros, 2011, Figura 18), no acampamento militar da Lomba do Canho, em contextos c. 60-40 a.C. (Fabião, 1989; Fabião, 2001), em, Santarém/Scallabis, integrando contextos c. 60-30 a.C., Fase 1, e posteriores (sem que se consiga precisar residualidade...) (Arruda, Almeida, 2001; Almeida, 2008), Mesas do Castelinho, em contextos tardo-republicanos (Parreira, 2009), em Castro Marim, também em contextos datados de 60-30 a.C. (Viegas, 2011) e talvez alguns exemplares do Castelo da Lousa (Morais, 2010; García Vargas, Almeida, González Cesteros, 2011, Figura 17).

Finalmente, ainda dentro da grande "categoria" dos contentores ovóides, podem ser incluídos alguns fragmentos, tipologicamente indeterminados, concretamente duas asas e vários fundos de difícil classificação, que podem pertencer simultaneamente a vários tipos de morfologia ovóide do Guadalquivir (ver Figura 12).

Quanto às asas, pequenas e com secção ovalada sem sulco, duas delas foram alvo de publicações recentes (Pimenta, Henriques, Mendes, 2012, 55; Fabião et al., 2016, 54-57). A presentam, com diferentes graus de preservação, a marca L.HORATI ( $L u$ cius Horatius) (Figuras 12, AC03 e 06), que merece um comentário particular. Em primeiro lugar, os exemplares conhecidos encontram-se em asas de pequena dimensão que pertencem, com grande probabilidade, a ânforas do período que antecede a mudança da Era, cronologia compatível com a do único caso com contexto seguro, o de Baetulo
(Badalona), do último quartel do séc. I a.C. (Comas I Solá, 1997; Fabião et al., 2016, 57). Em segundo lugar, porque nos últimos anos se multiplicaram as ocorrências no espaço hoje português, sendo a região do Império romano com maior número de achados. Esta marca está actualmente documentada em paragens tão distantes como o Castro de Vieito, Ponte de Lima (Silva, 2008) ou Mesas do Castelinho, Almodôvar - em contextos datados dos finais do século I a.C./inícios do I d.C. - mas destaca sobretudo a sua concentração no Vale do Tejo: dois (ou três) exemplares em Santarém, em contextos do final do séc. I a.C./inícios do I d.C. (Almeida, 2008, 177-8); os dois presentes exemplares de Alto dos Cacos (Pimenta, Henriques, Mendes, 2012, 55; Fabião et al., 2016, 56); e outros dois em Lisboa, concretamente no Teatro Romano, em contexto secundário de época medieval (Filipe, 2015), e no Claustro da Sé (Fabião et al., 2016, 55).

Indiscutivelmente mais numeroso e com maior peso no conjunto é o lote de peças importadas que se pode classificar como pertencente ao tipo Haltern 70. Trata-se do segundo tipo da Ulterior Bética (20\% das ânforas da província) e o primeiro do Vale do Guadalquivir ( $42 \%$ das ânforas dessa região), com maior expressão numérica/percentual no conjunto, concretamente 64 fragmentos $=30$ $\mathrm{NMI} / 16 \%$ do total do NMI.

O tipo Haltern 70 é seguramente um dos tipos que, por vários motivos, mais discussão tem gerado na bibliografia arqueológica (origem da forma, zonas de produção, cronologia inicial e final, conteúdos, etc..), mas assume-se hoje como sendo um contentor destinado a transportar conteúdos vitivinícolas ou outros produtos conservados em derivados vínicos, e o segundo grande contentor produzido no Vale do Guadalquivir, em várias das mesmas olarias que produziram a Dressel 20, o único tipo que as supera em exportação (García Vargas, 2001, 88). No entanto, sabe-se também que foi produzido em outras regiões da província - na Baía de Cádis, nas Marismas do Guadalquivir, o antigo Lacus Ligustinus, na área de Huelva e na Baía de Algeciras (Carreras Monfort, Berni Millet, 2016) - e nos últimos anos foi igualmente documentada a produção deste tipo (ou de tipos similares) em centros da Lusitânia costeira e interior (cf. Filipe, 2016, para uma síntese actualizada da problemática).

A evolução morfológica proposta, e ainda hoje aceite nos seus aspectos mais gerais, no que se refere particularmente aos fragmentos de bordo, define 

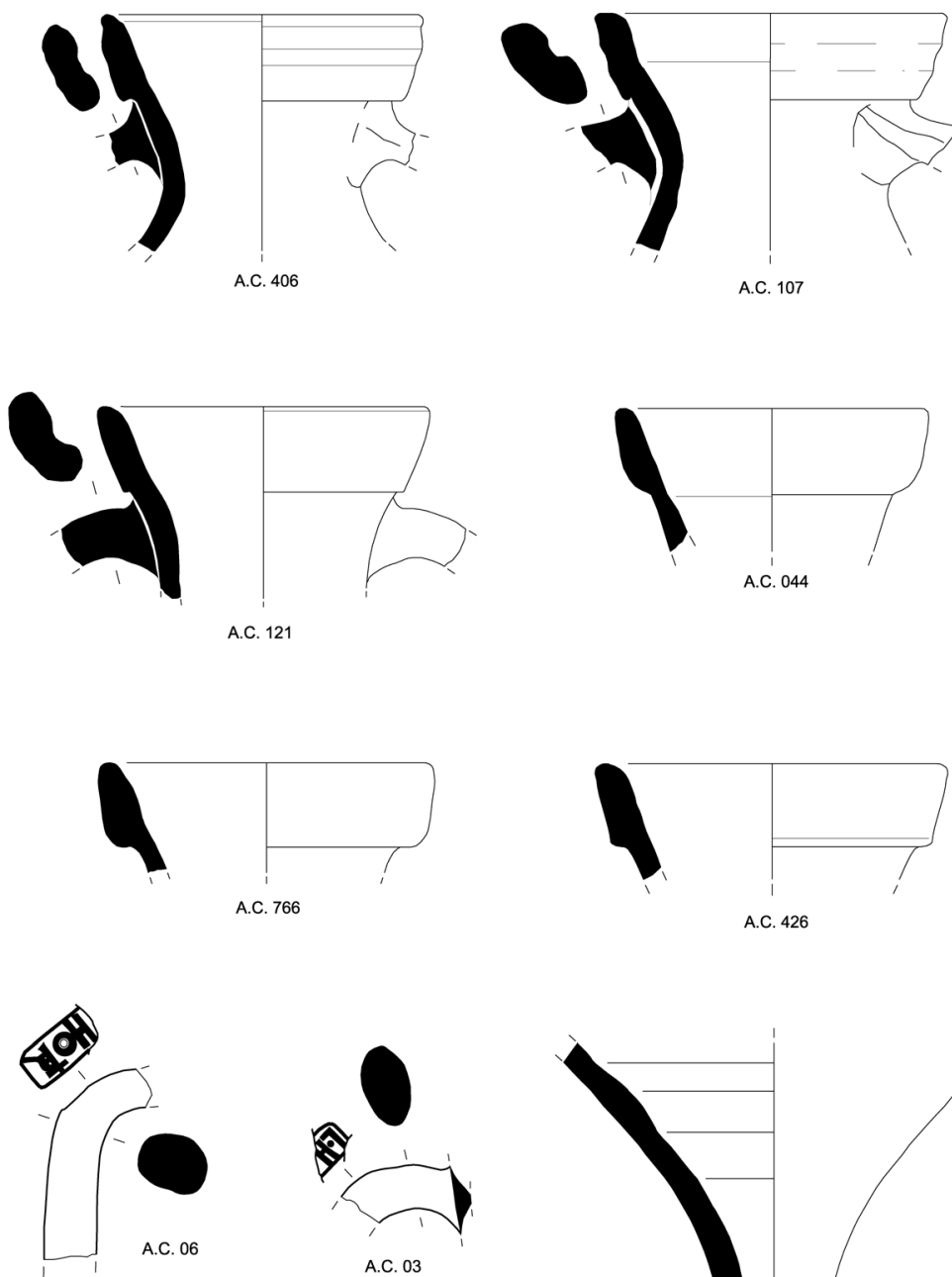

A.C. 426
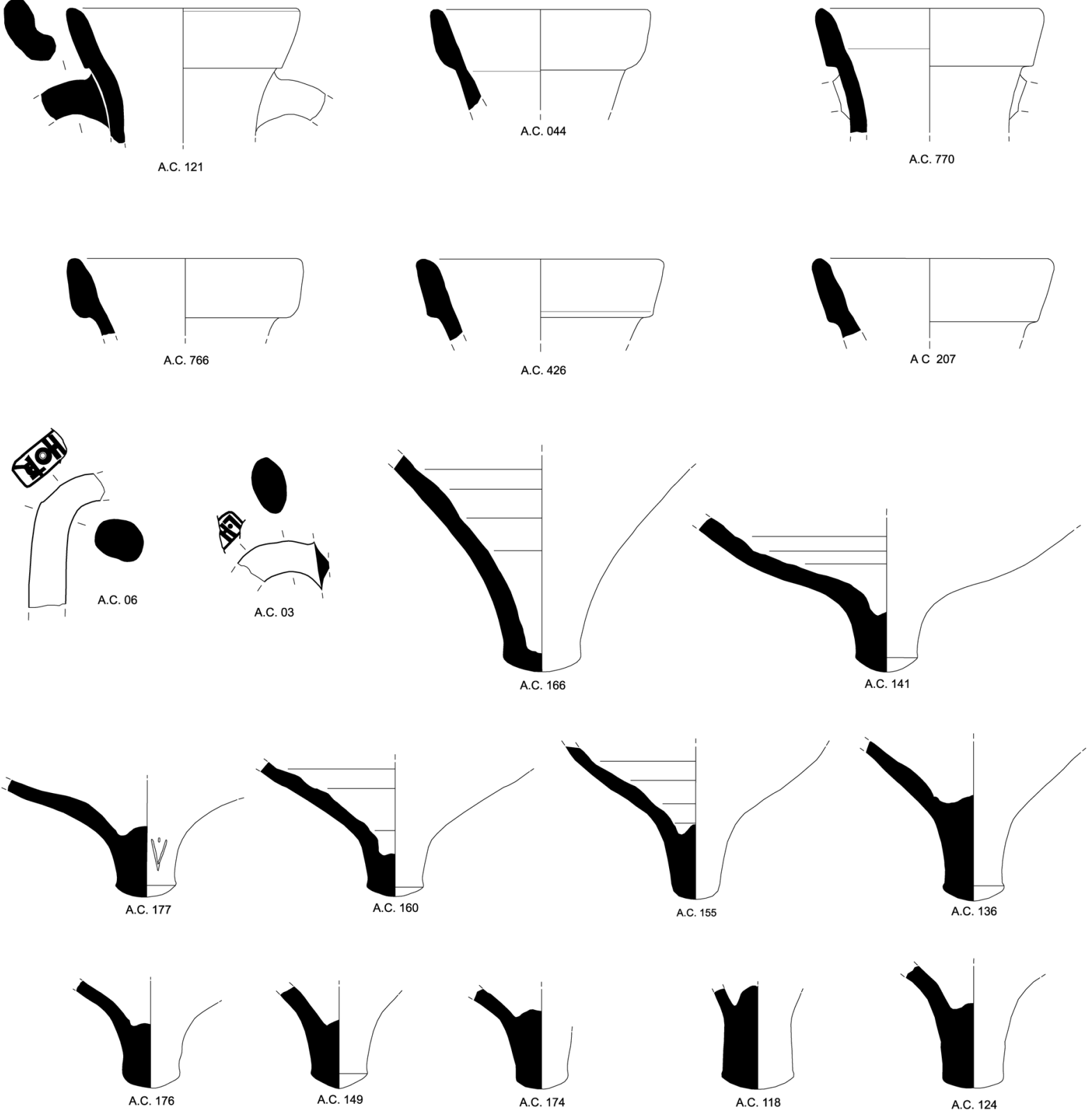

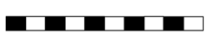

Figura 12. Ânforas da Ulterior/Bética, Vale do Guadalquivir. Ovóide 4: 406, 107, 111, 121, 44, 770, 766, 426, 207; Tipos ovóides indeterminados: 3, 6, 166, 141, 177, 160, 155, 136, 176, 149, 174, 118, 124. 
uma evolução desde lábios marcados em época de Augusto, com tendência a adquirirem maior comprimento e maior abertura para o exterior em época cláudia, atingindo perfis mais "atrompetados" e com ressalto suave na parte exterior do lábio em torno ao final da época júlio-cláudia, que se torna ainda mais comprido e estilizado em época flávia. Relativamente aos corpos, são cilíndricos desde um primeiro momento e tendem a reduzir-se em tamanho e a tornarem-se apontados nos anos finais da sua produção, em época tardo-flávia (Garcia Vargas, 2001, 88; Berni Millet, 2011).

Tal como se comentou anteriormente, o início da sua produção/circulação foi durante muito tempo situado em meados do século I a.C., senão mesmo no segundo quartel; contudo, e embora as últimas propostas de revisão se dividam, alguns autores advogam por uma manutenção da cronologia "tradicional" revista, avançando para meados do século I a.C. (Berni Millet, 2011; Carreras Monfort, Berni Millet, 2016); outros descartam tamanha antiguidade e fazem avançar a produção do tipo para o início do último terço do século I a.C., c. 30 a.C. (Almeida, 2008; García Vargas, Almeida, González Cesteros, 2011; García Vargas, González Cesteros, Almeida, no prelo), momento em que a Haltern 70 como tipo apresenta volume de produção e distribuição nas várias províncias ocidentais do império (Fabião, 2001, 668).

Relativamente à fachada atlântica peninsular, o seu estudo sistemático tem demonstrado a forte presença e importância destas ânforas, com uma predominância tanto no norte de Portugal como na Galiza e Astúrias (Carreras Monfort, 1996; Carreras Monfort, Berni Millet, 2003; Morais, 1998; Morais, 2001; Morais, 2004a - confirmando a primazia deste tipo e configurando-se um cenário de consumo em que o exército parece surgir como principal beneficiário do comércio das Haltern 70 no Noroeste, que tinham como principal destino as tropas acantonadas na Cantábria e nas Astúrias (Morais, Carreras Monfort, 2004, 97).

$\mathrm{Na}$ restante área atlântica, compreendendo o território actualmente português, as sínteses realizadas na década passada forneceram uma imagem muito completa da presença e distribuição do tipo (Morais, Carreras Monfort, 2004; Almeida, 2008), cuja base permanece totalmente válida, nos seus aspectos gerais. Observa-se ainda hoje que as áreas com maior concentração de achados se localizamna maior parte dos núcleos urbanos costeiros, com par- ticular incidência nos localizados junto aos estuários dos rios principais e no curso das vias fluviais de penetração interior. As cronologias apontadas para praticamente todos os sítios reportam-se na sua maioria ao período augusto-tiberiano, embora em alguns casos, designadamente nos dos núcleos indígenas com ocupação romana do Algarve e do Vale do Tejo, particularmente a cidade de Santarém, e os estabelecimentos da Estremadura e do Alentejo interior e central - os primeiros associados a presenças de efectivos militares e os segundos consistindo, na sua maioria, de estabelecimentos com forte cariz militar, ambos relacionados com o processo de conquista - possam apresentar alguns exemplares com cronologias dos últimos anos da República/primeiros do Principado.

A prática totalidade dos fragmentos de Alto dos Cacos (27 NMI) possui aspectos morfológicos que, em função das propostas tipológicas das últimas décadas (Martin-Kilcher, 1994; Carreras Monfort, 2003; Berni Millet, 2011; Carreras Monfort, Berni Millet, 2016), permitem genericamente considerá-los como "augustano-tiberianos"; contudo, entendemos que há que relativizar e comentar alguns aspectos desta classificação. A maioria dos fragmentos apresenta bordos curtos - entre 4 e $4,5 \mathrm{~cm}$ - e maciços, com perfil subrectangular engrossado, vários deles na sua parte superior, e claramente separados do colo, em forma de "colarinho" muito destacado. Se classificássemos estes fragmentos exclusivamente em função do parâmetro "altura do lábio", vários poderiam ser ainda atribuídos, no limite, ao tipo Ovóide 4; contudo, dado que a maior parte dos mesmos não apresenta colo nem asas conservadas, classificá-los como tal seria algo "forçado" (cf. García Vargas, Almeida, González Cesteros, 2011, 244248). Ao mesmo tempo, nos casos em que o mesmo existe, é possível verificar que se trata de colos de maior altura e com uma tendência mais cilíndrica do que propriamente bitroncocónica (Figura 14: AC420 e 427), alguns deles com asas mais compridas que, embora não tenham a métrica comum das asas da Haltern 70 "clássica”, já não se trata de asas nem de colos típicos de contentores de morfologia ovóide (Figura 14: AC152). A forma de alguns perfis de bordos e de colos, maciços e inclusivamente verticais, que fazem lembrar perfis de contentores itálicos, tanto de Dressel 1 como Lamboglia 2 (Figura 14: AC420, 427 e 429) - que se admite terem influenciado também na formação da Haltern 70 e de outros mais abertos (Figura 14: AC138) e igual- 
mente maciços, têm os seus melhores paralelos em exemplares do "Acampamento da frota de Agrippa”, em Fréjus (Goudineau, Brentchaloff, 2009, 546, planche. 1), entre outros sítios de referência, enquadráveis no último terço do século I a.C. como Cartago, datado entre 43 e 15 a.C. (Freed, 1996), Basileia entre 40 e 20 a.C. (Martin-Kilcher, 1999), Saint-Roman-en-Gal entre 30 e 20 a.C. (Desbat, Martin-Kilcher, 1989), o depósito de Loyasse em Lyon de cerca de 30 a.C. (Desbat, Lemaître, 2001), La Muette, em Lyon, datado de 20 a.C. (Desbat, Lemaître, 2001, 796 e fig.8) ou em Corts Valencianes, Valência, datados no último terço da centúria - com a associação entre uma Haltern 70 "mais típica” e uma morfologia ovóide (Pascual Berlanga, Ribera I Lacomba, 2001, 576) - ou ainda no naufrágio de Cabrera 4 (=Moro Boti), datado de cerca de 20 a.C. (Cerdá I Juan, 2000) e de Cabrera V, de 10 a.C. - 25 d.C. (Colls, Domergue, Guerrero Ayuso, 1986), no qual estão presentes morfologias próximas à típica Haltern 70, embora coexistam também exemplares de colos e asas curtas em corpos mais "bojudos" (cf. García Vargas, Almeida, González Cesteros, 2011, 244-248).

Ainda dentro deste subconjunto de fragmentos, gostaríamos de destacar o exemplar AC09 (Figura 13). Em primeiro lugar por considerarmos que se trata de um espécime "inicial” de Haltern 70, que apresenta o bocal completo, as duas asas pouco compridas e um colo bitroncocónico, mas não demasiado comprido, com uma altura total conservada de $22 \mathrm{~cm}$, preludiando o arranque de um corpo algo "bojudo". Em segundo lugar, porventura o mais interessante e importante, o facto de apresentar um titulus pictus em rubrum (Mun. $10 \mathrm{R}$ $5 / 8$ ), onde se pode ler L. FAN.VIC., para o qual se propõe a leitura, de $L$. Fan(ni) Vic(toris, -torini) ${ }^{3}$. A análise paleográfica da inscrição revela uma letra bem executada, com excepção da última letra $C$, de feitura muito fechada. Entendemos que a explicação para a mesma se deve tão somente a um detalhe técnico, provavelmente porque no movimento para escrever essa letra a mão de quem a realizou se viu condicionada/limitada pela presença da asa, faltando o espaço necessário para executar o movimento circular natural e correcto da letra C.

3 Agradecemos enormemente ao colega e amigo Dr. Piero Berni Millet, a preciosa e desinteressada ajuda prestada na leitura e compreensão do titulus.

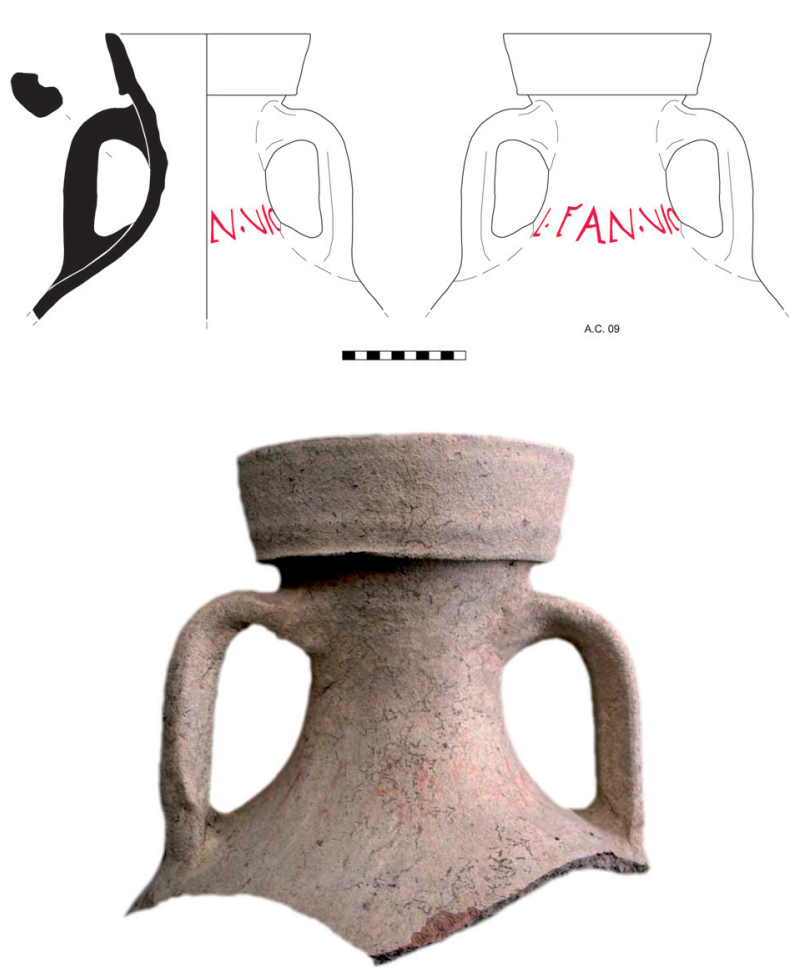

Figura 13. Ânfora da Bética, Vale do Guadalquivir. Haltern 70 com titulus pictus em rubrum.

$\mathrm{Na}$ actualidade conhecem-se cerca de meia centena de tituli em Haltern 70, a grande maioria com inscrições pintadas a negro (atramentum) contendo informação sobre o produto transportado - pelo menos oliva nigrae ex defruto e muria - sendo a tinta vermelha (rubrum) utilizada em inscrições secundárias (Aguilera Martín, Berni Millet, 1998; Aguilera Martín, 2004) em vários exemplares conhecidos, como por exemplo um de Pompeia (CIL IV, Suppl. II, 5585 apud Aguilera Martín, 2004).

Este achado é extremamente importante na medida em que a posição e o tipo da inscrição indicam que se trata de uma inscrição principal em rubrum, sem nenhuma indicação de conteúdo ou de outro tipo, provavelmente fazendo referência ao nome do comerciante. Assim, representa um esquema diferente da maioria dos casos conhecidos e registados (veja-se especialmente o corpus elaborado por A. Aguilera Martín, 2004) mas com grande similitude com o de uma Haltern 70 encontrada no muro de ânforas de Cartago, construído entre 43-15 a.C., com a maioria das peças colocadas entre 29-15 a.C. (Freed, 1996). Assim, esta peça de Alto dos Cacos, paralelamente à 

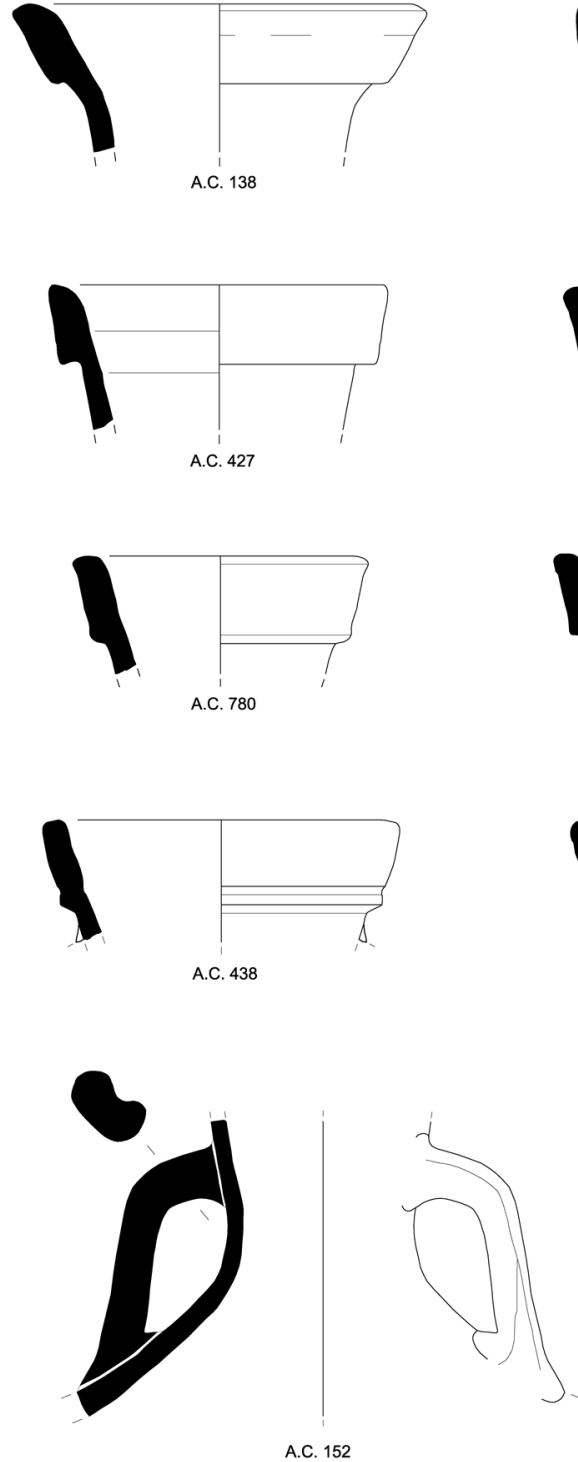

A.C. 152
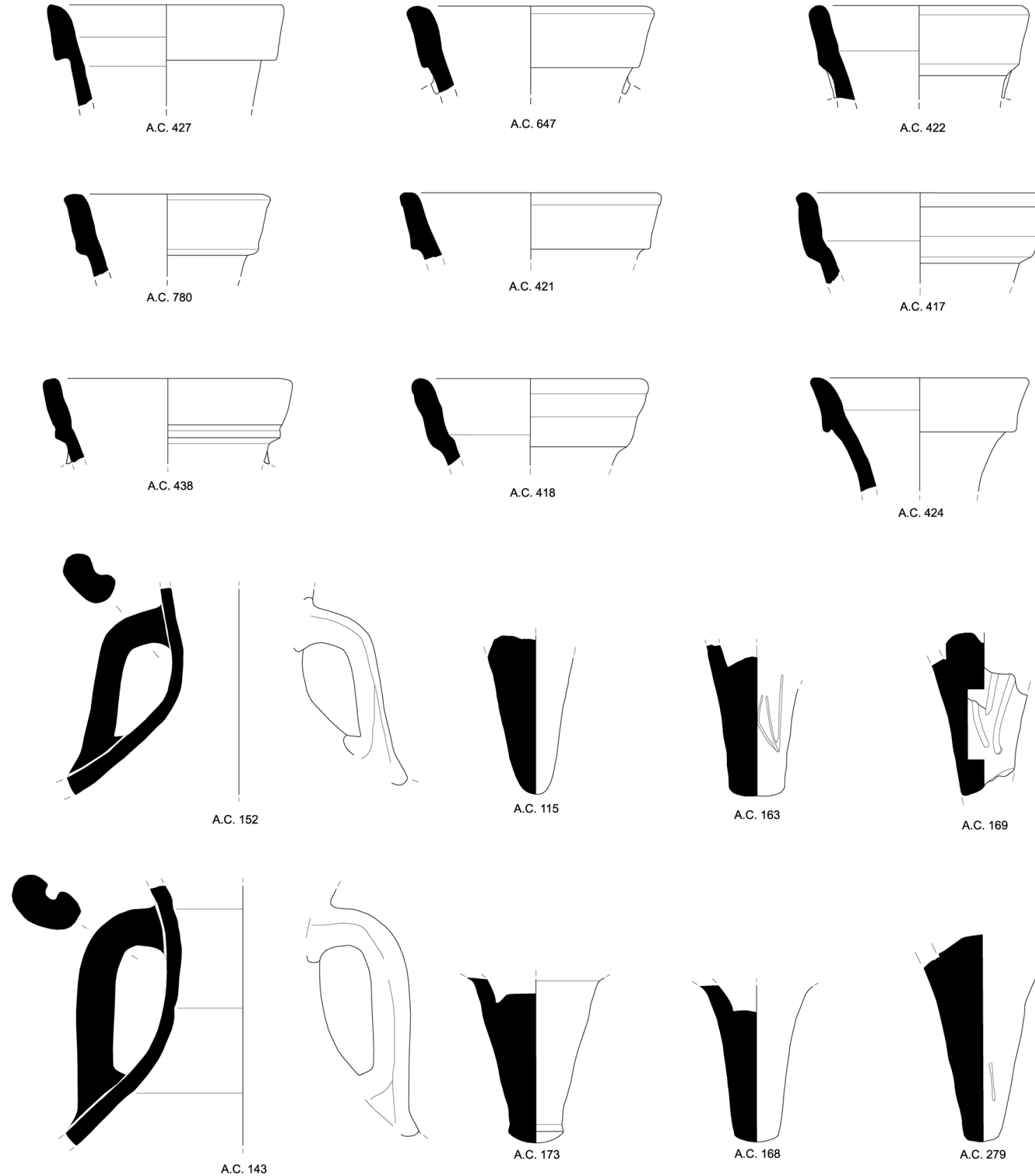

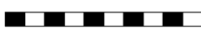
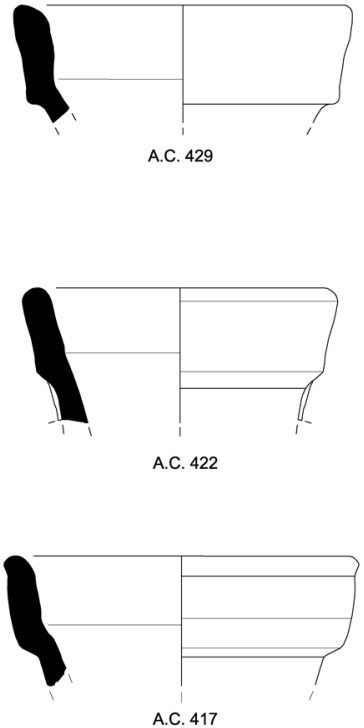

A.C. 422

A.C. 424

Figura 14. Ânforas da Bética, Vale do Guadalquivir. Haltern 70. 
referida de Cartago, pode representar um dos casos mais antigos de inscrições pintadas em Haltern 70.

Ainda quanto ao tipo Haltern 70, outro grupo de fragmentos é o constituído por bordos que apresentam perfis mais estilizados, menos maciços e menos destacados (por exemplo Figura 14, AC417, 418, $422,438)$. Estas características são as que geralmente se associam e se consideram típicas do período augustano, e que podem ser observadas nos exemplares do naufrágio do Culip VIII, datado de 20 a.C. - 20 d.C. e Cabrera 5, datado de 10 a.C. - 25 d.C. (Cerdá I Juan, 2000), ou em sítios terrestres como La Muette, de 20 a.C. (Desbat, Lemaître, 2001), e La Favorite, de época augustana (Becker et al., 1986), ambos em Lyon, ou ainda em estabelecimentos germânicos de carácter militar dos últimos dois decénios do século I a.C., como Dangstetten, datado de 15-9 a.C. (Ehmig, 2010), Rödgen, datado de 11/10-8 a.C. (Schönberger, Simons, 1976), ou a primeira fase do Kops Plateau de Nimega, datada de 12 a.C. - 10 d.C. (Almeida et al., 2014; Carreras Monfort, 2017).

Em função do exposto, constatamos que dentro do grande conjunto de exemplares de Alto dos Cacos integráveis no que genericamente se tende a considerar as Haltern 70 do período de Augusto/ Tibério, estão presentes quer fragmentos que apresentam morfologias ditas típicas de esse momento, como outras, de mais problemática classificação, que podem, talvez, ser atribuídos ao período de tempo que, conceptualmente, se pode considerar como o terminal do tipo Ovóide 4 e o das primeiras formas de Haltern 70, cronologicamente situável entre 3020/10 a.C., em que muitas das ânforas já enquadráveis neste último tipo possuiriam “(...) trazos morfológicos aún poco claros, fruto de una fase inicial de experimentación, que dificultan de sobremanera una correcta apreciación (...)" (García Vargas, Almeida, González Cesteros 2011, 223). Por outras palavras, entendemos que os exemplares de Alto dos Cacos que agora se publicam, com uma assumida variabilidade formal, correspondem aos primeiros momentos de produção/exportação do tipo, compreendidos entre o início da sua produção, em torno à década de 30 a.C., e a fase de consolidação da sua morfologia, em momentos augustanos, datados entre as duas últimas décadas antes da mudança da Era e as primeiras do século I d.C.; em termos morfo-tipológicos, correspondem a Haltern 70 "iniciais", que convivem com o tipo ovóide precedente, e que se podem documentar e encontrar a partir de 20-15 a.C. (García Vargas, Almeida, González Cesteros, 2011, 244 ss).
Bem diferente é o caso de outros dois fragmentos de bordo, concretamente os AC137 e 663 (Figura 15), cujas características morfológicas permitem-nos colocar algumas questões quanto ao momento cronológico concreto a que podem ser adscritos. Apresentam um perfil muito mais simples e estilizado que a esmagadora maioria dos fragmentos de Haltern 70 apresentados previamente. De facto, os presentes possuem bordos quase rectilíneos, praticamente sem ressalto exterior na parte inferior a marcar a ligação ao colo. Sobretudo este último aspecto, porventura um dos mais decisivos, costuma ser "mais constante e compatível" com os exemplares já de época Flávia - etapa 3 de S. Martin-Kilcher (1994), ou variante D de Baudoux (1996), que por sua vez é semelhante à variante que B. Dangréaux e A. Desbat propõe como tardia $(1988,121)$, que equivale à Fase IV de P. Berni (Berni Millet, 2011) e à Haltern 70D da mais recente síntese (Carreras Monfort, Berni Millet, 2016). Deste momento são alguns dos exemplares publicados de Augst (Martin-Kilcher, 1994), do naufrágio de Chiessi, Elba, datado de 60-85 d.C. (Zecchini, 1982) ou Marina di Fiori (Bernard, 2007), para referir apenas alguns dos mais conhecidos.

No entanto, é igualmente verificável que esses exemplares mais tardios mencionados possuem bordos significativamente mais altos e ainda mais estilizados que os exemplares de Alto dos Cacos; assim, é, justamente, a constatação destas pequenas diferenças que nos leva a colocar reticências quanto à sua classificação como típicos de época flávia e, ao mesmo tempo, e em detrimento da mesma, considerar que têm maior índice de semelhança e afinidade com exemplares definidos como de época cláudio-neroniana/início da flávia (50-80 d.C.) (Berni Millet, 2011, 92-94). Deste modo, parece-nos que estes fragmentos de Alto dos Cacos têm os seus melhores paralelos nos naufrágios de Port-Vendres II (Colls et al., 1977), Tour Saint-Marie (Laubenheimer, 1998) ou Ardenza (Bargagliotti, 2001), mas também em sítios "terrestres" como alguns dos depósitos de Saint-Just (Bértrand, 1992) ou Bas-de-Loyasse (Dangreaux, Desbat, 1988), datados da década de 70 d.C., entre outros igualmente emblemáticos... São também alguns dos tipos de bordos melhor representados em Santarém (Almeida, 2008) ou Braga (Morais, 2004b), em contextos datados estratigraficamente e por associações contextuais a outro tipo de materiais. 
Idêntica atribuição cronológica têm uns poucos fragmentos que são inquestionavelmente atribuíveis ao tipo alto-imperial oleário Dressel 20 (Figura 15), o tipo bético melhor conhecido, quer a nível epigráfico quer a nível tipológico, e seguramente um dos contentores mais difundidos no império romano a partir de momentos algo anteriores aos meados do século I d.C. ${ }^{4}$ Representam apenas 3 NMI e 1,6\% do conjunto.

Podemos observar que os fragmento de bordo AC436, 125 e 1 apresentam, com alguns matizes, as seguintes características: lábios com secção subcircular, ligeiramente engrossados na sua parte exterior e com interior pouco côncavo. Nenhum deles apresenta arestas incipientes na face externa, e apenas um (AC1) é ligeiramente achatado na sua parte superior, mas sem espessamento para o interior. A constatação destas características aliada ao profundo e esmiuçado conhecimento que existe actualmente dos principais atributos morfológicos e evolução formal das ânforas Dressel 20, permite classificar estes três fragmentos de bordo de Alto dos Cacos como típicos do período júlio-cláudio, em torno às décadas de 40-60 d.C. (Martin-Kilcher, 1987; Berni Millet, 1998; Berni Millet, 2008; Berni Millet, García Vargas, 2016).

Fazendo uso de (inevitáveis) comparações e analogias com exemplares "de referência" conhecidos, estes fragmentos de Dressel 20 de Alto dos Cacos têm os seus melhores paralelos nos documentados em sítios de produção como Las Delícias (Sáez Fernández et al., 2001; Mauné et al., 2014; Bourgeon et al., 2016) ou Sevilha (García Vargas, 2000; 2003), em sítios de consumo como Saint-Colombe (Helly, Bot-Helly, Liou, 1986), Porte d' Orée, em Fréjus (Laubenheimer et al., 1991) ou em vários naufrágios deste período como o de Cala Piombo (Galasso, 1997, 121), Lavezzi 2 (Bebko, 1971), Oscellucia (Liou, 2001, Lám.XI,9), Ille de Jarre (Pomey et al., 1989) ou Port-Vendres 2 (Colls et al., 1977).

4 É hoje em dia bem sabido que no estudo analítico das ânforas Dressel 20, tanto peças inteiras, como também de fragmentos, a maior parte dos seus atributos morfológicos (bordo, colo, asa, corpo, fundo) parecem ter grande relevância, já que representam diversas variantes que correspondem a diferentes etapas do desenvolvimento tipológico destes contentores, cuja produção parece manter-se até finais do século III d.C., pelo menos em época de Galieno, segundo datações consulares de 275 d.C. (Remesal Rodríguez, 1983; 1986; Rodríguez Almeida, 1984; Berni Millet, 1998; 2008; Berni Millet, García Vargas, 2016).
O mesmo parece verificar-se, desde um ponto de vista estritamente morfo-tipológico, com exemplares presentes em outros contextos mais próximos datados de idênticos momentos. De facto, estes exemplares recolhidos em Alto dos Cacos pertencem ao mesmo universo formal dos encontrados na Rua dos Remédios, em Lisboa, em contexto de época de Cláudio, datado de 45-50 d.C. (Silva, 2015; no prelo), na Praça da Figueira, no contexto [9033], datado de 50-60 d.C. (Silva, no prelo), ou na Fase 2 do Teatro romano de Lisboa, datada circa 57 d.C. (Filipe, 2015), onde são muito abundantes; por último, mas não menos importante, na cidade de Scallabis/Santarém, estes são também frequentes nos contextos da Fase 2 e início da Fase 3, isto é, durante o período júlio-cláudio e início do flávio (Almeida, 2008, 157-158 ss.)

Por último, refira-se ainda o achado de uma asa com uma marca, que foi recentemente publicada (Fabião et al., 2016, no 45c). Apesar da primeira letra se apresentar danificada pelo impacto de um instrumento cortante, provavelmente um arado, é possível constatar que se trata da marca LFO. O perfil da asa em forma de quarto de círculo, com a secção subcircular com uma suave nervura na parte superior e marca estampada de forma lateral também na área mais próxima do colo, costumam ser elementos característicos das asas de época júlio-cláudia/inícios da flávia (50-80 d.C.) Nesta caso concreto, a forma como a asa se implanta no colo, recta e quase a 90 graus, faz pensar numa asa mais comprida e com um desenvolvimento mais vertical, que seria já mais próprio de época flávia (Berni Millet, 2008, 59-60 e Fig. 32). A própria marca parece corroborar esta apreciação formal.

A marca LFO trata-se de uma marca que ainda hoje se desconhece o seu local de produção, mas que se sabe ter sido amplamente difundida por todo o Império Romano, desde Alexandria, a Roma e Ostia, na Gália e em diversos sítios no limes germânico ou na Grã-Bretanha. Com este tria nomina existem duas séries produzidas em épocas distintas: uma mais antiga, de meados do século I d.C., e no qual se parece inscrever o nosso exemplar, e outra mais recente, entre o final do século I e os inícios do II d.C. (apud Fabião et al., 2016, 53).

3.3. Produções da Ulterior ocidental e da Lusitânia (Vales do Tejo/Sado)

Os fragmentos de ânforas que se podem atribuir à produção da Ulterior ocidental e à posterior 

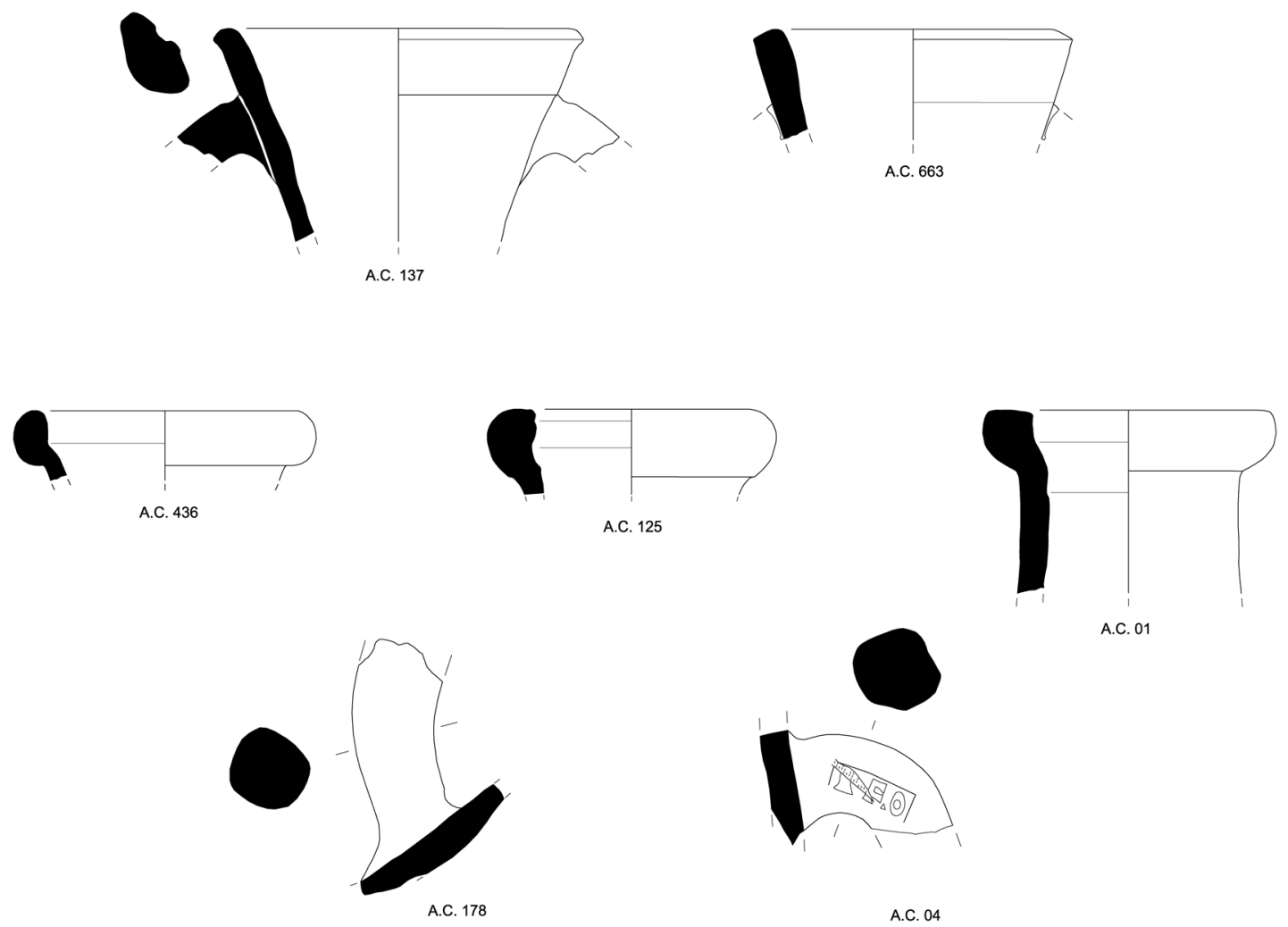

Figura 15. Ânforas da Bética, Vale do Guadalquivir. Haltern 70: 137, 663; Dressel 20: 436, 125, 1, 178, 04.

província da Lusitana - dependendo, claro está, do âmbito cronológico em que foram produzidas - apresentam, todas elas, pastas atribuíveis à macrorregião produtora dos Vales do Tejo/Sado. Perfazem um total de 42 fragmentos classificáveis, correspondendo a um NMI de 21 indivíduos e a $11,2 \%$ da amostra. A presença de contentores/produtos oriundos da Lusitânia revela a mesma tendência que as restantes regiões: uma forte presença de tipos relacionados com a ocupação mais antiga do sítio (25 NMI), e menor presença de tipos mais tardios (7 NMI), pertencentes a episódios posteriores de ocupação.

No período que pode ser enquadrado entre o final da República e os inícios do Principado, destaca o grupo das formas que pertencem ao momento inicial da produção romana na fachada atlântica da Ulterior futura província da Lusitânia, as ditas "Lusitanas Antigas", várias delas com aparente morfologia e conotações ovóides, composto por 25 fragmentos que correspondem a 13 NMI e a 7\% das ânforas recebidas/consumidas no sítio. Trata-se de um conjunto de fragmentos com bocais moldurados ou em fita simples, em forma de "colarinho" curto, e fundos que, pelas suas características formais, se aproximam em muito das primeiras produções de ânforas romanizadas da Ulterior/Bética, principalmente das Ovóide 1/Classe 67, Ovóide 4, das Dressel 10, 9 e 7 e da Haltern 70 (Figura 16) (Cf. Morais, 2004a; Arruda, Viegas, Bargão, 2006; Morais, Fabião, 2007; Morais, Filipe, 2016).

Uma das grandes interrogações, que se mantém na ordem do dia no que diz respeito à produção e tradição oleira de ânforas na província romana da Lusitânia, é precisamente a do seu início, quer em termos de cronologia quer em termos de enquadramento (Fabião, 2008, 502). Ainda que tenha sido proposta a existência de uma fase inicial de produção de ânforas de tipologia romana datada de época romana republicana (cf. Diogo, 1987, 182; Diogo, 
Faria, 1990, 95), só recentemente é que se começou a definir com base sólida assente em dados de índole estratigráfica (Morais, Fabião, 2007; Morais, Filipe, 2016; Pimenta, 2017; Mataloto, Williams, Roque, 2016), mas que, ainda assim, dada a escassez da sua representatividade e contextos, carecem de maior grau de conhecimento e precisão (García Vargas, Almeida, González Cesteros, 2011, 264-266; García Vargas, González Cesteros, Almeida, no prelo)

A questão de fundo, a de uma produção lusitana mais antiga, entenda-se anterior ao reinado de $\mathrm{Ti}^{-}$ bério, foi levantada na sequência da identificação de diversos conjuntos de ânforas de fabrico claramente lusitano, muitos deles evidenciando morfologia ovóide, recolhidos em contextos aparentemente tardo-republicanos e alto-imperiais (concretamente, de meados a finais do século I a.C.) provenientes de vários sítios da Galiza (Castro de Panxón, Montecastro e Castro de Vigo, Vigo), da região entre o rio Douro e Minho (Castro de Santa Luzia e Castro da Terronha, Viana do Castelo; Rua da Banharia e Aljube, Porto; e Castro de Fiães, Vila da Feira), e a Sul, no Vale do Guadiana, no sítio do Castelo da Lousa, Mourão (Morais, 2004a; 2010). Também em Santarém, no Vale do Tejo, foi detectada a sua presença em estratigrafia desde os primeiro momentos do Principado (Arruda, Viegas, Bargão, 2006).

Assim, o panorama da produção anfórica e da comercialização de produtos lusitanos a larga distância passou de estar assente em consolidadas sínteses que sublinhavam um carácter claramente de época imperial (cf. Fabião, 2004, 401) para a existência de uma produção com origem incerto, mas certamente atribuível à segunda metade do século I a.C. (Morais 2004a; Morais, Fabião 2007; García Vargas, Almeida, González Cesteros, 2011, 264).

Paralelamente, os estudos de diversos conjuntos de ânforas provenientes de centros de consumo, como as Ilhas Berlengas (Bugalhão, Lourenço, 2006), Santarém (Arruda, Viegas, Bargão, 2006), Coruche (Quaresma, Calais, 2005), Monte dos Castelinhos (Pimenta, Mendes, Norton, 2008), Lisboa (Filipe, 2008a; 2015), Alcácer do Sal (Pimenta et al., 2006; Pimenta, Sepúlveda, Ferreira, 2015), Castelo dos Mouros da Graça do Divor em Évora (Mataloto, 2008), o sítio de Soeiros em Arraiolos (Calado, Deus, Mataloto, 1999) e diversos fortins alentejanos da região de Monforte (Boaventura, Banha, 2006), atestavam uma ampla dispersão destes primeiros modelos de ânforas Lusitanas - vários deles aparentemente ovóides - permitindo assumir que se estava claramente perante uma verdadeira mudança de paradigma na "fase inicial da produção lusitana" (Morais, Fabião, 2007, 127). Infelizmente, grande parte deste relevante acervo de informação, carecia (e carece ainda...), de contexto primário e de associações estratigráficas seguras que permitam precisar a cronologia destas primeiras produções e dos seus ritmos comerciais.

Por outro lado o estado fragmentário da esmagadora maioria desses materiais impediu, e tem vindo a impedir, uma melhor tipificação destas ânforas (cf. Morais, Filipe, 2016). Conhecem-se apenas dois exemplares de perfil completo, depositados nos museus de Vila Franca de Xira e de Évora, mas trata-se de dois tipos relativamente mais tardios, aparentemente já de época imperial, concretamente uma Haltern 70 lusitana (Quaresma, 2005; Filipe, 2016) e um tipo que se tem relacionado com a Dressel 7 (Morais, Fabião, 2007, 128) e que foi definido como Lusitana 12 (Diogo, 1987).

Recentemente, o projeto de investigação estruturado em torno do sítio arqueológico de Monte dos Castelinhos, Vila Franca de Xira, tem permitido recolher novos dados bem estratigrafados relativos a estas primeiras produções lusitanas (Pimenta, Henriques, 2014; Pimenta, 2017). Resulta claro da leitura da sequência estratigráfica do sítio, que estas primeiras produções se encontram já presentes nos níveis de ocupação da primeira fase do sítio, datada de meados do século I a.C. e que estão bem atestados na sua fase de destruição, datada com segurança entre 50-30 a.C. (Pimenta, Mendes, 2014, 131). Nestes níveis, foi ainda possível recolher um exemplar com a parte superior bem conservada, que reproduz de forma bastante aproximada o modelo das ânforas Ovóide 1 do Guadalquivir (Pimenta, 2015, 154). Tendo em conta este exemplar é possível reavaliar todo um conjunto de materiais já publicados e que ora permitem sustentar a existência de uma produção no ocidente da Ulterior de uma reprodução/ forma afim da Ovóide 1/Classe 67. Os fragmentos de bordo AC642 e 108, correspondem precisamente a esta forma.

Já os restantes bordos, com perfis moldurados e ligeiramente abertos (AC1012, 773 e 771) ou com perfis em fita pequenos, são de mais difícil enquadramento. Não obstante, tendo em conta os exemplares melhor preservados e outros casos conhecidos - Santarém (Arruda, Viegas, Bargão, 2006), Lisboa-Teatro romano (Filipe, 2008; 2015), Lisboa-Rua dos Bacalhoeiros (Filipe, 2008b) - seja 

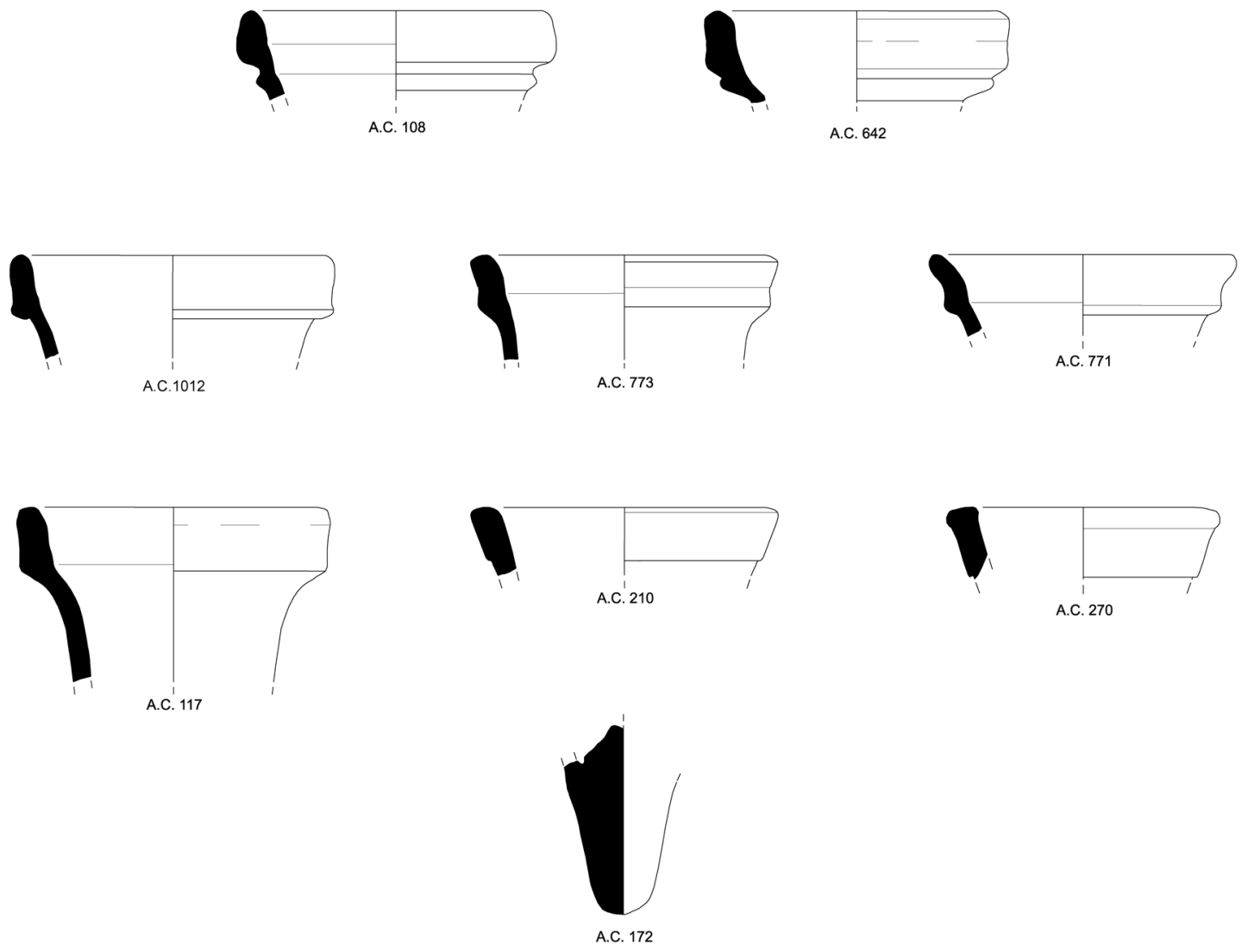

Figura 16. Ânforas da Ulterior/Lusitânia, Vales do Tejo/Sado. Tipos "Lusitanos Antigos": 108, 642, 1012, 773, 771, 117, 210, 270; Tipo “Lusitano Antigo" ou "Haltern 70" lusitana: 172.

possível sustentar a inclusão dos primeiros dentro de formas inspiradas/relacionadas com as primeiras séries dos tipos Dressel 7, 9 ou 10 da costa sudoeste da Ulterior Bética, como já outros propuseram (Morais, 2004a; Arruda, Viegas, Bargão, 2004; Morais, Fabião, 2007; Morais, Filipe, 2016); quanto aos segundos, a forma do bordo, colo e asas permitem também assimilá-los a outros contentores da Ulterior de morfologia ovóide, como a Ovóide 4 do Guadalquivir ou a "ovóide gaditana", e enquadrá- los no que parece ter sido uma morfologia particular que tem vindo a ser designada como Lusitana 12, ou ainda, dadas as evidentes similitudes, com a forma Haltern 70.

No que diz respeito aos centros produtores de onde terão saído estes contentores de produção mais antiga, permanecem ainda desconhecidos. É certo que se conheciam há já algum tempo vários locais onde se encontra documentada a produção, contextualmente datada no reinado de Tibério, de uma ânfora similar à Dressel 14, porém de menores dimensões que a forma canónica e evidenciando bocais moldurados, elemento característico das suas primeiras etapas de produção (Fabião, 2004, 395), mas que não pode ser propriamente classificada como "Lusitana Antiga". Ditas produções foram documentadas na olaria do Largo da Misericórdia, na área urbana da cidade de Setúbal (Silva, 1996) e nas olarias de Pinheiro e Abul (Mayet, Silva, 1998; 2002), já no interior do Baixo Sado, tendo por isso recebido a classificação de "Dressel 14 var. A" nas sistematizações regionais realizadas (Mayet, Silva, Schmitt, 1996; Mayet, Silva, 1998; 2002); mais recentemente também na área urbana de Alcácer do Sal, no Forno da Parvoíce (Pimenta et al., 2016). Uma eventual produção destes modelos iniciais é 
igualmente presumível para o sítio de Porto de Sabugueiro em Muge, no Baixo Tejo (Cardoso, 1990, 156). Contudo as datações apontadas para esses sítios não recuam para lá do período de Tibério...

O projecto de estudo em torno da olaria romana do Morraçal da Ajuda, em Peniche, veio aduzir novos dados a esta problemática sendo aparentemente o mais antigo centro produtor de ânforas romanas da Lusitânia que se conhece. Com início de produção no período de Augusto, aqui terão sido fabricados modelos anfóricos singulares, que não se encontram em nenhuma das outras regiões produtoras lusitanas, com evidentes afinidades morfológicas com formas de ânforas de salga de pescado alto-imperiais da Bética, e com outras morfologias, segundo as autores (Cardoso, Rodrigues, 2005; Cardoso, Rodrigues, Sepúlveda, 2006; Cardoso et al., 2016), mas que têm muito pouco parecido ou comum com os tipos de ânforas "antigas" encontradas nos sítios de consumo dos Vales do Tejo e do Sado.

Assim, dos centros oleiros enunciados, nenhum apresenta dados produtivos e cronologias compatíveis com os dos centros de consumo antes referidos - Santarém, Coruche, Lisboa, Alcácer do Sal, Castelo dos Mouros da Graça do Divor, Soeiros, Rocha da Mina, Castelo da Lousa. Situação diferente parece ser a que se pode esboçar a partir da olaria recentemente escavada na Rua António Joaquim Granjo, novamente na área urbana de Setúbal, na qual se identificou a produção de ânforas formalmente enquadráveis nas "Lusitanas Antigas", com morfologias ovóides ou outras relacionáveis com as béticas Dressel 7, 9 e 10, datadas de Augusto (Mayet, Silva, 2016, 64-65).

Em função do exposto, e particularmente à luz dos dados de Monte dos Castelinhos, demonstra-se a existência de uma produção e comercialização de ânforas ditas "Lusitanas Antigas" no Vale do Tejo a partir dos inícios da segunda metade do século I a.C., com particular incidência a partir do início do último terço da centúria, sendo neste cenário que se deve entender a sua recepção/consumo no sítio de Alto dos Cacos.

Por último, devemos ainda referir que as típicas produções anfóricas lusitanas de momentos posteriores estão também presentes em Alto dos Cacos, embora se encontrem escassamente representadas. Esta situação vai ao encontro dos aspectos supra referidos e comentados a propósito de vários tipos de ânforas béticas, tanto da Baía de Cádiz como do
Vale do Guadalquivir, mas sobretudo corrobora os elementos que o estudo da terra sigillata já tinha revelado: um progressivo declínio do sítio com os Flávios e o seu abandonado no século II d.C. (Silva, Pimenta, Mendes, 2013, 778).

Por outro lado, recolheram-se 5 fragmentos de Dressel 14, os contentores por excelência de transporte e comercialização de preparados piscícolas lusitanos entre meados do século I d.C. e os inícios do século III d.C. (Fabião, 2004; 2008), mas que representam somente $1 \mathrm{NMI}$ e $0,5 \%$ do total do conjunto (Figura 5).

Por outro, outros exemplares atestados, igualmente escassos, da forma Almagro 50 e Almagro 51C, dão testemunho de uma posterior reocupação do sítio, certamente em moldes muito diferentes, que poderá ter ocorrido a partir de meados do século III-IV d.C. Estas ânforas contabilizam 6 NMI e representam um total de $3,2 \%$ do conjunto. Correspondem a um indivíduo do tipo Almagro 50 e a cinco do tipo Almagro 51C.

Do primeiro, o tipo Almagro 50, recolheu-se um exemplar fragmentado de bordo com arranque de asa (Figura 17: AC206). No estado do conhecimento actual acerca dos centros oleiros na Lusitânia, é bem sabido que este contentor destinado a envasar preparados piscícolas se fabricou nas olarias dos Vale do Tejo e do Sado, e aparentemente em menor escala nas da costa Algarvia, tratando-se do segundo tipo lusitano mais produzido. Cronologicamente, o seu fabrico inicia-se na primeira metade do século III d.C. sendo amplamente comercializado e alcançando o século V d.C. (cf. Mayet, Silva, 2002; Fabião, 2004; 2008; Raposo, Almeida, 2016; Pinto, Almeida, Martin, 2016).

Ao segundo, o tipo Almagro 51C, forma 4 da tipologia lusitana (Diogo, 1987), pertencem cinco fragmentos de bordo e outros de asas e fundo (Figura 5), que contabilizam 5 NMI. Trata-se sem dúvida do principal contentor de transporte/comércio de preparados piscícolas lusitanos em época tardia, com um enorme volume de produção em inúmeras olarias dos vales dos rios Tejo/Sado e costa Algarvia, e que conheceu grande distribuição por todo o mundo romano, tal como podemos deduzir da sua presença numa considerável quantidade de naufrágios e lugares de consumo. Ao nível da cronologia, os dados disponíveis permitem situar o seu início em meados do século III e o seu fim em finais do século $\mathrm{V}$, talvez mesmo nos inicios do VI d.C. (cf. 

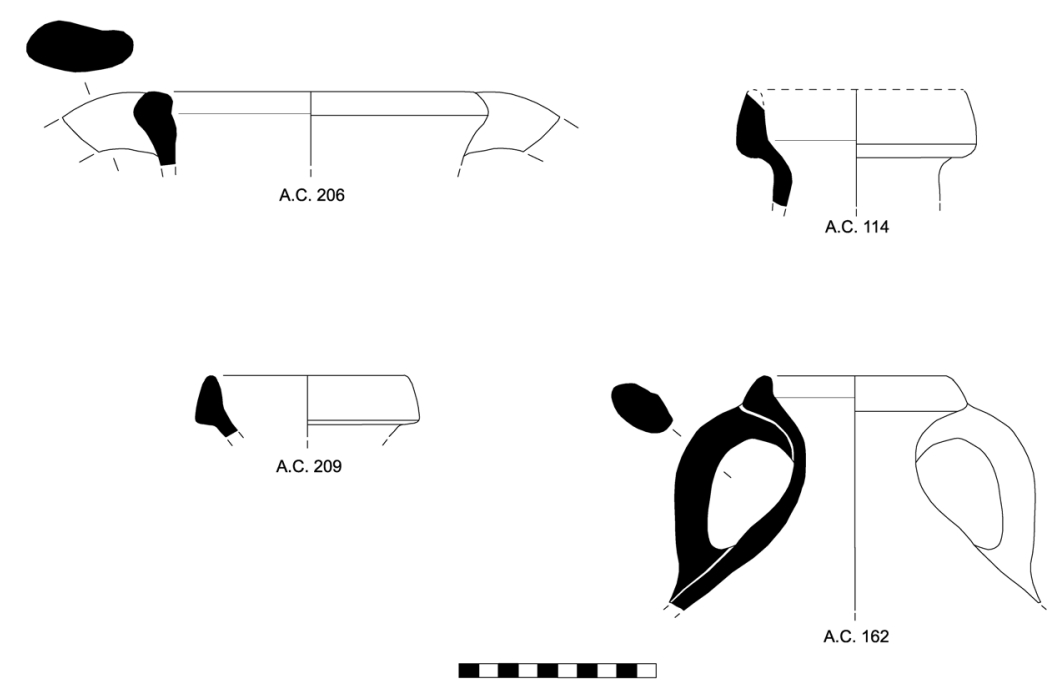

Figura 17. Ânforas da Lusitânia, Vales do Tejo/Sado. Almagro 50: 206; Almagro 51C: 114, 209, 182.

Alarcão, Mayet, 1990; Mayet, Silva, 2002; Fabião, 2004; 2008, Viegas, Raposo, Pinto, 2016; Viegas 2016; Pinto, Almeida, Martín, 2016).

\section{Algumas CONSIDERAÇõES FINAIS}

Embora o historial em torno à estação de Alto dos Cacos tenha sido pautado por profundas destruições que a delapidaram de forma irreversível e que fizeram com que tenha acabado por cair no esquecimento, o recente projecto de investigação em que este trabalho se insere tem permitido reabilitar a sua relevância científica.

O conjunto de ânforas, recolhido quer na sequência das destruições de inícios dos anos oitenta do século passado, quer nos recentes trabalhos de prospecção aí desenvolvidos, permitiu-nos analisar detalhadamente um número de 379 fragmentos diagnosticáveis e passíveis de ser classificados, cujo estudo resultou de 188 o número mínimo de indivíduos (NMI) quantificados, convertendo-o numa dos mais significativas amostragens, em termos numéricos e estatísticos, conhecidas para o ocidente do território actualmente português. Ao mesmo tempo, o conjunto das ânforas apresenta uma homogeneidade e coerência cronológica assinaláveis, que vão ao encontro do que tem vindo a sobressair do estudo de outros conjuntos parciais entretanto publicados, como a cerâmica de verniz negro, a terra sigillata, as paredes finas, o espólio metálico e numismático (Pimenta, Mendes, Henriques, 2014).

Apesar de este conjunto carecer de coordenadas contextuais, revela uma ocupação centrada na segun- da metade do século I a.C. e meados do I d.C., e outra de carácter vestigial, de época tardo-antiga. Mas o mais destacável, e que não deixa de surpreender, é o facto de o grosso do conjunto (c. de $90 \%=170$ NMI) reflectir claramente um cenário de recepção/ consumo que diz respeito a um período de tempo relativamente curto, que, tal como fomos discutindo e (consideramos que) justificando ao longo deste trabalho, pode ser enquadrado e entendido entre o final da República o início do Principado.

As correlações de materiais cerâmicos e metálicos recolhidos em Alto dos Cacos, encontram bons paralelos em contextos do século I a.C., particularmente em sítios de cariz ou conotação militar, como o acampamento romano da Lomba do Canho (Fabião, 1989), a Alcáçova de Santarém (Arruda, Almeida, 2000; Viegas, 2003; Bargão, 2006; Almeida, 2008), o Monte dos Castelinhos, em Vila Franca de Xira (Pimenta, Mendes, 2014; Pimenta, 2015), o Pedrão, em Setúbal (Soares, Silva, 1973), Mesas do Castelinho (Fabião, 1998b; Parreira, 2009) e o Castelo da Lousa (Alarcão, Carvalho, Gonçalves, 2010; Morais, 2010) ou Castro Marim (Viegas, 2011). Contudo, mesmo relativamente a estes, apresenta também ligeiras diferenças, particularmente no que à origem, tipos de ânforas e importância dos mesmos se refere.

No que diz respeito às importações itálicas de vinho, tomemos como referência Scallabis/Santarém, por exemplo, o vizinho imediato, localizado em frente na outra margem do Tejo. Aqui, nos contextos do segundo quartel e de parte do terceiro 
quartel do século I a.C. as ânforas Dressel 1 são hegemónicas e constituem aproximadamente metade da amostra total do sítio, sendo as Lamboglia 2 apenas vestigiais (Arruda, Viegas, 2014). Já para Alto dos Cacos, se o mesmo se verifica para as produções adriáticas, já o mesmo não se pode dizer para as primeiras; de facto, as Dressel 1 destacam pela sua escassa representatividade ( $5 \%$ do NMI), ao mesmo tempo que chama a atenção uma presença inusual, por acima da média, de ânforas do tipo Ovóide 4 do Guadalquivir (11\% do NMI), a que talvez pudesse caber a responsabilidade do comércio de produtos de idêntica natureza, tal como às Haltern 70 (16\%), mas já com origem na Ulterior/Bética e suplantando claramente o vector itálico.

Relativamente aos contentores testemunho do comércio do azeite, confirma-se uma ínfima presença dos tipos com origem no sul da Itália (1\%), valores que se inscrevem perfeitamente no cenário do actual território português, como nos demonstram novamente Santarém e Monte dos Castelinhos, na geografia mais próxima, e Lomba do Canho ou Castro Marim, em extremos mais longínquos. $\mathrm{O}$ que se destaca, novamente, é a presença "mais significativa" dos tipos da Ulterior, concretamente os Ovóides 6 e 7 do Vale do Guadalquivir (admitindo-se que alguns dos segundos poderiam ainda pertencer e incrementar o primeiro tipo, o Ovóide 6), aos quais se atribui o comércio do azeite deste província. Digna de registo é também a total ausência de ânforas africanas, particularmente do tipo "Africano Antigo", uma presença constante e importante elemento de diagnóstico, com particular incidência em contextos da segunda metade do século II a.C. e primeira metade do I a.C.

Por último, no que concerne às ânforas que poderão corresponder à evidência do comércio dos produtos piscícolas, destaca a baixa frequência do tipo punicizante Mañá C2b (3\% do NMI) e a presença esmagadora dos tipos "ovóide gaditana" (9 $\%$ do NMI), Classe $67(4 \%)$ e as primeiras Dressel 7-11 (29 \% do NMI), que, conjuntamente com dois hipotéticos exemplares de Dressel 12, abarcam quase metade do conjunto das ânforas (47\% do total NMI). De facto, estas são as "cotas de mercado" verificadas nos sítios com conjuntos quantificados e com amostras estatisticamente mais significativas (Santarém, Castro Marim e Mesas do Castelinho, por exemplo), mas nestes domina o tipo Mañá C2b no conjunto das importações da baía gaditana em momento localizado em torno aos meados do sécu- lo I a.C. (Arruda et al., 2006), em detrimento das ovóides gaditanas e primeiras séries das Dressel 7-11. Por outras palavras, ao contrário do verificado em Alto dos Cacos.

Ainda dentro deste último grande grupo torna-se obrigatório mencionar a expressiva presença das ânforas "Lusitanas Antigas" (8\% do NMI). Em que contexto e em que moldes é que se terá dado início à produção de ânforas no território actual português, é ainda uma das questões em aberto e para a qual necessitamos mais dados conclusivos. Contudo, não deixa de ser pertinente supor que, tal como acontece na Bética (Fabião, 2001, 673), o início da produção/difusão de ânforas no espaço ocidental da Ulterior correspondente à futura província da Lusitânia possa estar intimamente conotado com os contingentes militares e a necessidade de suprir as dificuldades de abastecimento de produtos alimentares localmente.

A modo de síntese, a conjugação de determinados aspectos do conjunto, como a escassa representatividade das ânforas vinárias itálicas e dos típicos contentores de preparados piscícolas na baía Gaditana, as ânforas Mañá C2b, aliados a uma forte representação dos tipos ovóides da costa e do interior da Ulterior/Bética e dos tipos de consolidação em época Imperial inicial, configuram, do nosso ponto de vista, uma questão cronológica. É sabido que as produções ovóides tardo-republicanas do Guadalquivir estão presentes e são já parte integrante da rede de produtos/abastecimento destinado aos destacamentos militares, pelo menos desde a época do pretorado de César, mas que se acentua ao longo da segunda metade do século I a.C. (Almeida, 2008, 282).

Assim, o sítio de Alto dos Cacos parece corresponder a um padrão de recepção/consumo de produtos alimentares já de momentos terminais da República e inicios do último quartel do século I a.C., quando os produtos do Vale do Guadalquivir, conjuntamente com os da área da costa sudoeste, maiormente da Baía de Cádis, e da fachada ocidental atlântica da Ulterior/Bética (primeiras produções dos Vales do Tejo/Sado), monopolizam o abastecimento. Traduzido em anos de calendário, poderia estar hipoteticamente compreendido entre 50/40 e 20/10 a.C., com maior peso e importância, dada a sua aparente natureza militar, nas primeiras décadas.

Como enquadrar então a ocupação de Alto dos Cacos e as provas da abundante recepção de contentores/artigos que aí terá ocorrido? Realizando 
uma sinopse dos dados conhecidos para o período em apreço, constatamos que as atividades bélicas e a presença de tropas nesta área do Baixo Vale do Tejo decorre da ocupação militar da cidade de Scallabis. Tal como a maior parte da Hispania, esta região parece ter vivido um período de relativa estabilidade após o final do conflito sertoriano, que só veio a ser alterada com a chegada de Júlio César à Hispania Ulterior, em 61-60 a.C., para desempenhar o cargo de procônsul ou propretor. Consciente da importância económica e estratégica da área do Baixo Tejo, o futuro ditador ter-se-ia estabelecido em Scallabis, tal como indica a referência de Plínio (PLIN.4,117), e aí teria instalado o seu Praesidium Iulium (Alarcão, 1988).

A identificação da actual vizinha cidade de Santarém com Scallabis - a povoação indígena na qual foi instalado o Praesidium, posteriormente colónia, capital de civitas e de conventus - é hoje um dado adquirido, cimentado nos avultados vestígios resultantes dos trabalhos arqueológicos das últimas duas décadas (Arruda, Viegas, 1999; 2002; Viegas, 2003; Almeida, 2008; Arruda, Viegas, 2014). No que diz respeito ao local concreto, a sua instalação na área da Alcáçova de Santarém parece fundamentada na extensão, cronologia unitária das construções e características do tipo de implantação romana, bem como a cultura material aí identificada e exumada. As próprias dimensões da Alcáçova concordam com as necessárias à instalação de um praesidium, destinado a albergar uma coorte ou uma guarnição inferior a uma legião, tal como propôs J. de Alarcão $(2002,39)$.

Não existia, porém, consenso em relação à cronologia do mesmo. A data de 61 a.C., contemporânea da presença de César como propretor da Hispania Ulterior, ou 49-44 a.C. correlacionada com a guerra civil entre o ditador e Pompeio foram as propostas inicialmente por J. de Alarcão (1988, 26), e mais recentemente, após alguns considerações críticas de A. Faria sobre o tema $(1999,43)$, J. de Alarcão propôs como mais credível uma cronologia de 49-44 a.C. (Alarcão, 2002, 39). Não obstante, a avultada cultura material recuperada na Alcáçova de Santarém, e também recentemente sintetizada (Arruda, Viegas, 2014), é claramente atribuível ao segundo quartel do século I a.C., devendo, assim, descartar-se a segunda proposta.

Tal como referimos supra, ainda que a informação disponível com que lidamos neste estudo careça de confirmação estratigráfica, julgamos de- fensável avançar-se com a proposta de estarmos perante uma ocupação de índole militar em Alto dos Cacos, com início na segunda metade do século I a.C. (50-40 a.C.), pelo que se poderia, desta feita, estar perante uma instalação militar correlacionável com o período de instabilidade reinante no Ocidente resultante da eclosão e desenvolvimento do conflito entre os partidários de César e Pompeio na Ulterior, durante o qual a Península Ibérica voltou a ser palco de importantes episódios da luta pelo poder (Fabião, 1998b). A presença de grandes contingentes militares, e as múltiplas referências nas fontes clássicas à presença de legiões estacionadas no ocidente peninsular, permitem ainda inferir que este conflito terá sido decisivo para a romanização da Lusitânia (Alarcão, 1988, 27).

Finda esta fase conturbada, com a Pax Augusta todo o vale do Tejo é integrado numa nova estrutura política à escala global de um Império. Através de referências em diversos textos clássicos (Plínio, Ptolomeu e o Itinerário de Antonino), sabemos que o povoado indígena implantado no morro da Alcáçova da vizinha Santarém, sobre o qual se tinha antes instalado o Praesidium Iulium, foi então escolhido para a implantação da cidade romana de Scallabis (Arruda, Viegas, 1999; Viegas, 2003). Ainda através de Plínio (IV, 117), sabemos que a esta urbe do Vale do Tejo foi conferido o estatuto de colónia, uma das cinco existentes na província da Lusitânia, e que teve um papel de relevo incontestado a nível político, administrativo, judicial e económico, como sede de um dos três Conventos Jurídicos da província romana da Lusitânia (Guerra, 1995, 35). Independentemente da questão exacta de fundação da colónia, de ser uma criação de César ou já de Augusto, não sendo este o sítio para discutir esta questão, que aliás não é ainda tema pacífico (cf. Mantas, 1993; Faria, 1999; Arruda, Viegas, 1999; Alarcão, 2002; Viegas, 2003), o que parece ser indiscutível é que teve na sua génese uma origem militar, inserindo-se a sua fundação numa estratégia de defesa ou prevenção da linha do Tejo e no gizar de um primeiro programa de criação de cidades de estatuto privilegiado e de uma política coerente de colonização, que corresponde na Península Ibérica ao final das guerras civis entre César e Pompeio (Mantas, 1993).

A dedução da colónia de Scallabis terá tido, assim, um forte impacto em toda a sua envolvente, em particular entre as populações indígenas que habitavam esta fértil região. A chegada e implantação de um conjunto considerável de colonos, 
possivelmente veteranos das campanhas de César, desencadeou um processo de enérgicas transformações no território, que segundo alguns autores ainda hoje marcam a paisagem (Quinteira, 1996). A implantação da colónia terá tido, desse modo, efeitos práticos sobre o seu território. De facto, implícito à implantação dos colonos encontra-se a centuriação do seu território, que terá passado de mãos das comunidades indígenas para os novos habitantes terratenentes, a quem terá sido entregue uma parcela de terreno a explorar. Segundo Vasco Mantas, "não faltam vestígios dessa grande operação de ordenamento económico e administrativo, cujo módulo foi o da centuria quadrata de 50 hectares $(710 \times 710 m)$." (Mantas, 2002, 111).

Entendemos que é no contexto deste novo desenho político que no sítio de Alto dos Cacos, outrora acampamento, se assiste à continuidade da sua ocupação, ou a uma reocupação de diferente natureza. Tal como pudemos constatar do estudo das ânforas, e complementarmente de outras classes cerâmicas, designadamente a terra sigillata, está comprovada a sua ocupação ao longo do século I d.C., pelo menos até ao início de época flávia, uma fase já de paz e num novo cenário que se encontrava a implantar no território, relacionado com a fundação e implementação física da colonia scallabitana. Poderia ainda considerar-se a possibilidade de o acampamento de Alto dos Cacos ter-se mantido como elemento estruturante e estruturador de uma nova paisagem política, podendo inclusivamente os militares ter tido um papel de relevo na construção dessa paisagem, quer com acções físicas como no assegurar de obras de engenharia essenciais como as construções viárias, quer assumindo com a sua presença uma acção no parcelamento do território da colónia.

Por último, cabe ainda referir os escassos vestígios de uma fase/episódio de ocupação desta área já em época tardia (séculos III e IV d.C.). Face à parca evidência, é apenas possível conjecturar que nesta fase se está ante outro tipo de utilização do espaço, provavelmente uma instalação de cariz rural, que se estabeleceu na mesma zona do antigo acampamento ou nas suas imediações.
Bibliografía

Alarcão, J. (1988), O Domínio Romano em Portugal, Lisboa.

Alarcão, J. (2002), "Scallabis e o seu território", De Scallabis a Santarém. Catálogo da exposiçao, Lisboa, Museu Nacional de Arqueologia, 37-46.

Alarcão, J., Carvalho, P. C. y Gonçalves, A. (2010), Castelo da Lousa. Intervenções Arqueológicas de 1997 a 2002, Stvdia Lvsitana 5, Mérida, Museo Nacional de Arte Romano / Edia,

Almagro, M. (1955), Las necrópolis de Ampurias, Barcelona.

Aguilera Martín, A. (2004), "Epigrafia Sobre Àmfores Haltern 70 Bètiques. Los Tituli Picti”, Culip VIII i les Àmfores, Haltern 70, Monografies del Casc, 5, Girona, Museu d'Arqueologia de Catalunya / Centre d'Arqueologia Subaquàtica de Catalunya, 139-147.

Aguilera Martín, A. y Berni Millet, P. (1998), "Las cifras hispánicas”, Rubrica. Paleographica et Diplomatica Studia, 7, 257-282.

Almeida, R. R. (2008), Las Ánforas del Gualdalquivir en Scallabis (Santarém, Portugal). Aportación al Conocimiento de Los Tipos Minoritarios, Col.Leció Instrumenta 8, Barcelona, Publications de la Universitat de Barcelona.

Almeida, R. R. (2010), “The incorporation of the Baetican Hinterland into the Western supply during the Late Republic. A reading based on the distribution of the Guadalquivir's minority amphora types", The Western Roman Atlantic Façade. A study of the economy and trade in the Mar Exterior from the Republic to the Principate (Carreras Monfort, C. y Morais, R. Eds.), BAR Int. Ser. 2162, Oxford, 191-196.

Almeida, R. R. de, Berg, J. van der, Berni Millet, P., Schimmer, F. y Carreras Monfort, C. (2014), "El comercio de ánforas hispanas en Kops Plateau (Nijmegen) desde época de Augusto a época flavia”, As produções cerâmicas de imitação na Hispania - II Congresso Internacional da Secah, Ex Officina Hispana (Braga 2013), Braga, 379-392.

Almeida, R. R. de y González Cesteros, H. (2017), "Las ánforas lusitanas en los origenes del mundo romano septentrional", Amphorae from the Kops Plateau (Nijmegen). Trade and supply to the Lower-Rhineland from the Augustan period to AD 69/70 (C. Carreras Monfort y Berg, 
J. van den Eds.), Archaeopress Roman Archaeology 20, Oxford, 87-92.

Aquilué, X., Castanyer, P., Santos, M. y Tremoleda, J. (2002), "El Campo de Silos del área Central de la Ciudad Romana de Empúries”, Romula, 1, 9-38.

Aquilué, X., Castanyer, P., Santos, M. y Tremoleda, J. (2004), "Geografia del Consum de les Haltern 70. Les Àmfores Haltern 70 d'Empúries”, Culip VIII i les Àmfores, Haltern 70, Monografies del Casc, 5, Girona, Museu d'Arqueologia de Catalunya / Centre d'Arqueologia Subaquàtica de Catalunya, 112-117.

Arruda, A. M. (1996), "O Castelo de Castro Marim”, De Ulisses a Viriato, O Primeiro Milénio a.C. Catálogo da Exposição, Lisboa, Instituto Português de Museus / Museu Nacional de Arqueologia, 95-100.

Arruda, A. M. y Almeida, R. R. de (1998), "As ânforas da Classe 32 da Alcáçova de Santarém”, Conímbriga, 37, 201-231.

Arruda, A. M. y Almeida, R. R. de (1999), “As Importações de Vinho Itálico Para o Território Português. Contextos, Cronologias e Significado", III Table Ronde Sur la Lusitanie Romaine, Collection de la Casa de Velázquez 65, Madrid, Casa de Velázquez, 307-337.

Arruda, A. M. y Almeida, R. R. de (2001), "Importação e consumo de vinho bético na colónia romana de Scallabis", Congreso Internacional Ex Baetica Amphorae. Conservas, Aceite y Vino de la Bética en el Império Romano (Écija-Sevilla 1998), Vol II, Écija, Editorial Sol, 703-715.

Arruda, A. M. y Sousa, E. (2013), "Ânfora republicanas de Monte Molião (Lagos, Algarve, Portugal)", SPAL, 22, 101-141.

Arruda, A. M. y Viegas, C. (1999), “A Roman Temple in Santarém - Portugal”, Journal of Iberian Archaeology, 1, 185-224.

Arruda, A. M. y Viegas, C. (2002), “A Alcáçova”, De Scallabis a Santarém. Catálogo da exposiçao, Lisboa, Museu Nacional de Arqueologia, 73-82.

Arruda, A. M. y Viegas, C. (2014), "Santarém durante a época romano-republicana”, Atas do Congresso Internacional de Arqueologia Conquista e Romanização do Vale do Tejo (Vila Franca de Xira, 2013), Cira Arqueologia 3, Vila Franca de Xira, Museu Municipal de Vila Franca de Xira, 242-255.

Arruda, A. M. y Viegas, C. (2016), “As ânforas al- to-imperiais de Monte Molião", Amphorae ex Hispania: paisajes de producción y consumo (Tarragona, 2014) (R. Járrega Dominguez, R. y Berni Millet, P. Eds.), Monografías Ex Officina Hispana 3, Tarragona, ICAC, 446- 463.

Arruda, A. M., Viegas, C. y Bargão, P. (2005), “As ânforas da bética costeira na Alcáçova de Santarém”, Revista Portuguesa de Arqueologia, 8.1, 279-297.

Arruda, A. M.; Viegas, C. y Bargão, P. (2006), "Ânforas lusitanas da Alcáçova de Santarém", Simpósio internacional produção e comércio de preparados piscícolas durante a Proto- História e a época Romana no Ocidente da Península Ibérica - Homenagem a Françoise Mayet (Setúbal, Maio 2004), Setúbal Arqueológica 13, Setúbal, 233-252.

Arruda, A. M.; Viegas, C.; Bargão, P. y Pereira, R. (2006), "A importação de preparados de peixe em Castro Marim: da Idade do Ferro à Época Romana”, Simpósio Internacional Produção e comércio de preparados piscícolas durante a Proto-História e a época Romana no Ocidente da Península Ibérica - Homenagem a Françoise Mayet (Setúbal, Maio 2004), Setúbal Arqueológica 13, Setúbal, 153-176.

Baldacci, P. (1972), "Importazioni Cisalpine e Produzione Apula”, Recherches sur les Amphores Romaines, Collection de l'École Française de Rome 10, Roma, 7-28.

Bargão, P. (2006), As importações anfóricas durante a época romana republicana na $\mathrm{Al}$ cáçova de Santarém. Tese de Mestrado em Pré-história e Arqueologia, Lisboa, Universidade de Lisboa. http://repositorio.ul.pt/handle/10451/447

Bargagliotti, S. (2001), "Il relitto dell'Ardenza (Livorno): un carico di anfore betiche naufragato intorno alla metà del I sec. d.C.”, Congreso Internacional Ex Baetica Amphorae. Conservas, Aceite y Vino de la Bética en el Império Romano (Écija-Sevilla 1998), Vol. III, Écija, Editorial Sol, 1111-1119.

Baudoux, J. (1996), Les Amphores du Nord-Est de la Gaule, DAF 52, Paris.

Bebko, W. (1971), "Les épaves antiques du sud de la Corse". Cahiers Corsica, 1-3. Bastia.

Becker, C., Constantin, C., Desbat, A., Jacquin, L. y Lascoux, J.-P. (1986), "Le dépôt d'amphores augustéen de la rue de la Favorite à Lyon", Figlina, 7, 65-89. Lyon. 
Beltrán Lloris, M. (1970), Las Ânforas Romanas en España, Zaragoza.

Beltrán Lloris, M. (2001), "Ánforas béticas en la Tarraconense: bases para una síntesis”, Congreso Internacional Ex Baetica Amphorae. Conservas, Aceite y Vino de la Bética en el Império Romano (Écija-Sevilha 1998), Vol. II, Écija, Editorial Sol, 441-537.

Benoit, F. (1956), "Épaves de la cote de Provence. Typologie des Amphores”, Gallia, 14, 23-34.

Bernal Casasola, D. (2007), "Vinos tarraconenses más allá de las Comunas de Hércules. Primeras evidencias en la Baetica, Lusitania y Tingitana”, La producció $i$ el comerç de les àmfores de la Provincia Hispania Tarraconensis. Homenatge a Ricard Pascual i Guasch, Monografies Museu d'Arqueologia de Catalunya 8, Barcelona, 319-352.

Bernal-Casasola, D.; García Vargas, E., Sáez Romero, A. M. (2013), "Ánforas itálicas en la Hispania meridional”, IMMENSA AEQUORA Workshop. Ricerche archeologiche, archeometriche e informatiche per la riconstruzione dell'economia e dei commerci nel bacino occidentale del Mediterraneo (metà IV sec. a. C.-I sec. a. C.) (Olcese, G. Dir.), Roma, Edizioni Quasar, 351-372.

Bernal Casasola, D. y Jiménez-Camino Álvarez, R. (2004), "El taller de El Rinconcillo en la bahía de Algeciras. El factor itálico y la economía de exportación (ss. I a. C.- I d. C.)", Figlinae Baeticae. Talleres Alfareros y Producciones Cerámicas en la Bética Romana (ss. II a.C. - II d.C.) (Cádiz, 2003) (Bernal Casasola, D. y Lagóstena Barrios, L. Eds.), B.A.R. International Series 1266, Oxford, 589-606.

Bernal Casasola, D. y Lagóstena Barrios, L. (2004), Figlinae Baeticae. Talleres Alfareros y Producciones Cerámicas en la Bética Romana (ss. II a.C. - II d.C.) (Cádiz, 2003), B.A.R. International Series 1266, Oxford.

Bernard, H. (2008), "Nouvelles épaves hispaniques de Corse: Sud Perduto 2 (Bonifacio) et Marina di Fiori (Porto Vecchio)", Comercio, Redistribución y Fondeaderos. La navegación a vela en el Mediterráneo. V Jornadas Internacionales de Arqueología Subacuática (Pérez Ballester, J y G. Pascual Berlanga, G. Eds.), Valencia, 461-471.

Berni Millet, P. (1998), Las ánforas de aceite de la Bética y su presencia en la Cataluña roma- na, Col.Leció Instrumenta 4, Barcelona, Publications de la Universitat de Barcelona.

Berni Millet, P. (2008), Epigrafía anfórica de la Bética. Nuevas formas de análisis. Col.lecció Instrumenta 29, Barcelona, Publications de la Universitat de Barcelona.

Berni Millet, P. (2011), “Tipología de la Haltern 70 bética", Ánforas romanas de Lugo, Traballos de Arqueoloxía 3, Lugo, 80-107.

Berni Millet, P. y García Vargas, E. (2016), "Dressel 20 (Valle del Guadalquivir)", Amphorae ex Hispania. Paisajes de producción y de consumo (http://amphorae.icac.cat/amphora/dressel-20-guadalquivir-valley), 23 noviembre, 2016. (Consulta 19-IX-2017)

Bertrand, E. (1992), "Les amphores d'un vide sanitaire du 1er siècle à Lyon (Saint-Just). SFECAG. Actes du Congrès de Tournai (1992), Marseille, 265-277.

Boaventura, R., Banha, C. (2006), “Ânforas da região de Monforte: contributo para o conhecimento do comércio rural romano", O Arqueólogo Português, Série IV no 24, 360-399.

Boube, J. (1979-1980), “Amphores prérromaines trouvées en mer au voisinage de Rabat", Bulletin d'Archéologie Marocaine, 12, Rabat, 163235.

Bourgeon, O., García Vargas, E., Mauné, S., Corbeel, S., Carrato, Ch., García Dils, S. y Vázquez Paz, J. (2016), "Investigación arqueológica en el alfar de las Delicias (Écija, Sevilla) 2013-2015: un primer balance", Amphorae ex Hispania: paisajes de producción y consumo (Tarragona, 2014) (R. Járrega Dominguez, R. y Berni Millet, P. Eds.), Monografías Ex Officina Hispana 3, Tarragona, ICAC, 310-333.

Bugalhão, J., Lourenço, S. (2006), “As ânforas romanas da Ilha da Berlenga”, Simpósio Internacional Produção e comércio de preparados piscicolas durante a Proto-História e a época Romana no Ocidente da Península Ibérica - Homenagem a Françoise Mayet (Setúbal, Maio 2004), Setúbal Arqueológica 13, Setúbal, 279-294.

Calado, M., Deus, M., Mataloto, R. (1999), “O sítio dos Soeiros (Arraiolos): uma abordagem preliminar", Actas do Congresso de Proto-História Europeia - Centenário da morte de Martins Sarmento, Revista de Guimarães - $\mathrm{n}^{\mathrm{o}}$ especial, Guimarães, Sociedade Martins Sarmento, 759774. 
Cardoso, G. (1990), "O forno de ânforas de Muge", Les amphores lusitaniennes. Typologie, production et commerce (Conimbriga, 1988) (Alarcão. A. y Mayet, F. Eds.), Paris, E. De Boccard, 153-165.

Cardoso, G. y Rodrigues, S. (2005), “Olaria romana do Morraçal da Ajuda”, Actas do Congresso A Presença Romana na Região Oeste, Bombarral, Câmara Municipal do Bombarral, 83-102.

Cardoso, G., Rodrigues y S., Sepúlveda, E. (2006), "A olaria romana de Peniche" In Simpósio Internacional Produção e comércio de preparados piscícolas durante a Proto-História e a época Romana no Ocidente da Península Ibérica. Homenagem a Françoise Mayet. Setúbal Arqueológica, Vol. 13, p. 253-278.

Cardoso, G.; Rodrigues, S.; Sepúlveda, E. y Ribeiro, I. (2016), "Production during the Principate in Peniche (Portugal)". Raw Materials, Kilns and Amphora Typology. In I.V. Pinto, R.R de Almeida, A. Martin (eds.). Lusitanian Amphorae: Production and Distribution. Roman and Late Antique Mediterranean Pottery, 10. Oxford, p. 3-17.

Carre, M.-B. y Mattioli, S.P. (2003), "Tentativo di classificazione delle anfore olearie adriatiche", Aquileia Nostra, LXXIV, 453-476.

Carre, M.-B., Monsieur, P. y Pesavento Mattioli, S. (2014), "Transport amphorae Lamboglia 2 and Dressel 6A: Italy and/or Dalmatia? Some clarifications", Journal of Roman Archaeology, 27, 417-428.

Carreras Monfort, C. (1996), "El comercio de Asturias a través de las ánforas”, Los Finisterres Atlánticos en la Antigüedad (Gijón, 1993) (Fernández Ochoa, C. Coord.) Gijón, 205-210.

Carreras Monfort, C. (2003), "Haltern 70: a review", Amphorae in Britain and in the Western Empire (London, 1994), Journal of Roman Pottery Studies 10, 85-91. London.

Carreras Monfort, C. (2017), "The Significance of the Haltern 70 Amphorae on the Kops Plateau", Amphorae from the Kops Plateau (Nijmegen): trade and supply to the Lower-Rhineland from the Augustan period to AD 69/70 (Carreras Monfort, C. y Berg, J. van den Eds.), Oxford, Archaeopress Publishing Ltd, 61-74.

Carreras Monfort, C. y Berni Millet, P. (2003), "Ánforas", Astorga IV. Lucernas y Ánforas (Amaré, T. Dir.), Léon, 635-673.

Carreras Monfort, C. y Berni Millet, P. (2016),
"Haltern 70 (Valle del Guadalquivir)”, Amphorae ex Hispania. Paisajes de producción y de consumo (http://amphorae.icac.cat/amphora/ haltern-70-guadalquivir-valley), 08 julio, 2016 (Consulta 30-XI-2017).

Cavalier, M. (1985), "Capo Graziano, Relitto C di Età Augustea”, Archeologia Subacquea, Bolletino d'Arte Suppl. no 29, 92-93.

Cerdá I Juan, D. (2000), Les àmfores salseres a les Illes Balears, Palma, Consell Insular de Mallorca.

Cipriano, S. y Mazzochin, S. (2017), "Western Adriatic amphorae productions: the research status", ADRIAMPHORAE. Amfore kao izvor za rekonstrukciju gospodarskoga razvoja jadranske regije u antici: lokalna proizvodnja / Amphorae as a resource for the reconstruction of economic development in the Adriatic region in Antiquity: local production (Radovi $s$ okruglog stola Zagreb, 21. travnja 2016. g. / Proceedings of the workshop Zagreb, 21st April 2016) (Lipovac Vrkljan, G., Radić Rossi, I. y Konestra, A. Eds.), Zagreb, 33-47.

Cipriano, M-T. y Carre, M-B. (1989), "Production et typologie des amphores sur la côte adriatique de l'Italie", Amphores Romaines et Histoire Économique: Dix Ans de Recherches (Actes du Colloque de Siena, 1986), Collection de L'École Française de Rome 114, Rome, 67-104.

Colls, D., Domergue, C. y Guerrero Ayuso, V. (1986), "Les lingots de plomb de l'épave Cabrera 5, Île de Cabrera, Baleares”, Archaeonautica, 6, Paris, Editions du CNRS, 31-80.

Colls, D., Étienne, R., Lequément, R., Liou, B. y Mayet, F. (1977), “L'Épave de Port-Vendres II et le Commerce de la Bétique à L'Époque de Claude, Archaeonautica 1. Paris, Editions du CNRS.

Comas i Solá, M. (1985), Baetulo. Les Àmfores, Monografies Badalonines 8, Badalona.

Comas i Solá, M. (1997), Baetulo. Les marques d'àmfora, Barcelona, Inst. d'Estudis catalans.

Dangreaux, B. y Desbat, A. (1988), "Les amphores du depotoir flavien du Bas-de-Loyasse à Lyon”, Gallia, 45, 115-153.

Desbat, A. y Lemaître, S. (2001), "Les premieres importations d'amphores de Bétique à Lyon”, Actas del Congreso Internacional Ex Baetica Amphorae. Conservas, Aceite y Vino de la Bética en el Império Romano (Écija-Sevilha 1998), Vol. III, Écija, Editorial Sol, 793-816. 
Desbat, A. y Martin-Kilcher, S. (1989), "Les amphores sur l'axe Rhône-Rhin à l'époque d'Auguste", Amphores Romaines et Histoire Economique : Dix Ans de Recherches (Actes $d u$ Colloque de Siena, 1986), Collection de L'École Française de Rome 114, Roma, 203-213.

Desy, P. (1989), Les timbres amphoriques de l'Apulie républicaine. Documents pour une histoire économique et sociale, BAR International Series 554, Oxford.

Diogo, A. M. D. (1984), "O material romano da $1^{\text {a }}$ campanha de escavações na Alcáçova de Santarém (1979)", Conimbriga, 23, 111-142.

Diogo, A. M. D. (1987), "Quadro tipológico das ânforas de fabrico lusitano”, O Arqueólogo Português, Série $I V-n^{\circ}$ 5, 179-191.

Diogo, A. M. D. (1999), "Ânforas provenientes de achados na costa marítima portuguesa", Revista Portuguesa de Arqueologia, 2.1, 235-248.

Diogo, A. M. D. y Faria, J. C. L. (1990), “Elementos para a caracterização e periodização da economia do Baixo Sado durante a época romana", Arqueologia Hoje. I. Etno-Arqueologia, Faro, Universidade do Algarve, 92-106.

Diogo, A. M. D. y Trindade, L. (1993-94), "Materiais provenientes de Chões de Alpompé (Santarém)", Conimbriga, 32-33, 263-281.

Ehmig, U. (2010), Dangstetten IV. Die Amphoren. Untersuchungen zur Belieferuq einer Militaranlage in augusteischer Zeit und den Grundlagen archaologischer Interpretation von Fund und Befund, Forschungen und Berichte zur vor-und Frithgeschichte in Baden-wurttemberg Band 117, Stuttgart.

Ehmig, U. (2013), "Les traces des dernières Dressel 1 entre Rhin et Danube", Itinéraires des vins romains en Gaule, IIIe - Ier siècles avant J.-C. Confrontation de faciès (Lattes, février 2007) (Olmer, F. Ed.), Lattes, 371-375.

Empereur, J.Y. y Hesnard, A. (1987), "Les amphores hellénistiques”, Céramiques hellénistiques et romaines II (Leveque, P. y Morel, J.-P. Eds.), Annales littéraires de l'Université de Besançon 331, Paris, 9-72.

Étienne, R. y Mayet, F. (2000), Le Vin Hispanique. Trois Clés Pour l'Économie de l'Hispanie Romaine, Paris, De Boccard.

Étienne, R. y Mayet, F. (2002), Salaisons et sauces de poisson hispaniques, Paris, De Boccard.

Fabião, C. (1987), "Ânforas romanas republicanas de um depósito de Mértola no Museu Nacional de Arqueologia e Etnologia”, O Arqueólogo Português, Série $I V-n^{\circ}$ 5, Lisboa, 125-148.

Fabião, C. (1989), Sobre as ânforas do acampamento romano da Lomba do Canho (Arganil), Cadernos da UNIARQ 1, Lisboa, Instituto Nacional de Investigação Científica.

Fabião, C. (1998a), “O vinho na Lusitânia: reflexões em torno de um problema arqueológico", Revista Portuguesa de Arqueologia, 1.1, 169-198.

Fabião, C. (1998b), O Mundo Indígena e a sua Romanizaçao na Área Céltica do Territorio Hoje Português, Tese de Doutoramento em Arqueologia, Lisboa, Faculdade de Letras de Universidade de Lisboa. Lisboa.

Fabião, C. (2001), "Sobre as mais antigas ânforas romanas da Baetica no Ocidente Peninsular", Actas del Congreso Internacional Ex Baetica Amphorae. Conservas, Aceite y Vino de la Bética en el Império Romano (Écija-Sevilha 1998), Vol. II, Écija, Editorial Sol, 665-682.

Fabião, C. (2004), "Centros oleiros da Lusitânia. Balanço dos conhecimentos e perspectivas de investigação”, Figlinae Baeticae. Talleres Alfareros y Producciones Cerámicas en la Bética Romana (ss. II a.C. - II d.C.) (Cádiz, 2003) (Bernal Casasola, D. y Lagóstena Barrios, L. Eds.), B.A.R. International Series 1266, Oxford, 379-410.

Fabião, C. (2008), "Las ánforas de Lusitania”, Cerámicas hispanorromanas: un estado de la cuestión (Bernal Casasola, D. y Ribera i Lacomba, A. Eds.), Cádiz, Universidad de Cádiz, 725745 .

Fabião, C. y Pimenta, J. (Coord.) (2014), Atas do Congresso Internacional de Arqueologia Conquista e Romanização do Vale do Tejo (Vila Franca de Xira, 2013), Cira Arqueologia 3, Vila Franca de Xira, Museu Municipal de Vila Franca de Xira.

Fabião, C., Guerra, A., Almeida, J., Almeida, R. R. de, Pimenta, J. y Filipe, V. (2016), Marcas de ânforas romanas na Lusitânia (do Museu Nacional de Arqueologia de Lisboa ao Museo Nacional de Arte Romano de Mérida), Corpus Internationale des Timbres Amphoriques Fascicule 19), Lisboa, Union Académique Internationale / Academia das Ciências de Lisboa / Uniarq.

Faria, A. M. (1999), “Colonização e municipalização nas províncias hispano-romanas: reanálise de alguns casos polémicos", Revista Portugue- 
sa de Arqueologia, 2.2, 29-50.

Filipe, V. (2008a), As ânforas do teatro romano de Lisboa, Tese de Mestrado em Pré-História e Arqueologia, Lisboa, Faculdade de Letras da Universidade de Lisboa (http://repositorio. ul.pt/handle/10451/471).

Filipe, V. (2008b), "Importação e exportação de produtos alimentares em Olisipo: as ânforas romanas da Rua dos Bacalhoeiros”, Revista Portuguesa de Arqueologia, 11.2, 301-324.

Filipe, V. (2015), "As ânforas do teatro romano de Olisipo (Lisboa, Portugal): campanhas 20012006, Spal, 24, 129-163.

Filipe, V. (2016), "Haltern 70 (Lusitania Occidental)", Amphorae ex Hispania. Paisajes de producción y de consumo (http://amphorae. icac.cat/amphora/haltern-70-western-lusitania), 21 julio, 2016. (Consulta 15-XI-2017).

Freed, J. (1996), "Early roman amphoras in the collection of the museum of Carthage", Echos du monde classique / Classical Views, 15.1, 119-156.

Galaso, M. (1997), "Rivenimenti Archeologici Subaquei in Sardegna Sud-Occidentale e Nord-Occidentale”, Atti del Convegno Internazionale della Ceramica, 21-133.

García Vargas, E. (1996), "La Producción anfórica en la Bahía de Cádiz durante la República como índice de romanización”, Habis, 27, 49-62.

García Vargas, E. (1998), La producción de ánforas en la bahía de Cádiz en época romana: (siglos II a.C - IV d.C), Écija.

García Vargas, E. (2000), “Ánforas romanas producidas en Hispalis. Primeras evidencias arqueológicas", Habis, 31, 235-260.

García Vargas, E. (2001), "La producción de ánforas "romanas" en el sur de Hispania. República y Alto Império, Actas del Congreso Internacional Ex Baetica Amphorae. Conservas, Aceite y Vino de la Bética en el Império Romano (Écija-Sevilla 1998), Vol. I, Écija, Editorial Sol, 57-174.

García Vargas, E. (2003), "Las producciones de la figlina. Anforas”, Arqueología y Rehabilitación en el Parlamento de Andalucía. Investigaciones Arqueológicas en el Antiguo Hospital de las Cinco Llagas de Sevilla (Vázquez Labourdette, A. Ed.), Sevilla, 200-219.

García Vargas, E. (2010a), “Ánforas béticas de época augusteo-tiberiana. Una retrospectiva”, Las necrópolis de Cádiz. Apuntes de arqueología gaditana en homenaje a J. F. Sibón Olano (Niveau de Villedary, A. M. y Gómez, V. Coords.), Cádiz, 582-622.

García Vargas, E. (2010b), "Formal Romanisation and atlantic projection of amphorae from the Guadalquivir Valley", The Western Roman Atlantic Façade. A study of the economy and trade in the Mar Exterior from the Republic to the Principate (Carreras Monfort, C. y Morais, R. Eds.), BAR Int. Ser. 2162, Oxford, 55-65.

García Vargas, E. (2012), "Producciones anfóricas tardorrepublicanas y tempranoaugusteas del valle del Guadalquivir. Formas y ritmos de la romanización en Turdetania a través del artesanado cerámico", Cerámicas Hispanorromanas II. Producciones Regionales (Bernal Casasola, D. y Ribera i Lacomba, A. Eds.), Cádiz, Universidad de Cádiz, 177-206.

García Vargas, E., Almeida, R. R. de y González Cesteros, H. (2011), "Los tipos anfóricos del Guadalquivir en el marco de los envases hispanos del siglo I a. C. Un universo heterogéneo entre la imitación y la estandarización”, Spal, 20, 185-283.

García Vargas, E., Almeida, R. R. de y González Cesteros, H. (2016a), "Ovoide 4 (Valle del Guadalquivir)”, Amphorae ex Hispania. Paisajes de producción y de consumo (http://amphorae.icac.cat/amphora/ovoid-4-guadalquivir-valley), 20 julio, 2016. (Consulta 18-IX-2017)

García Vargas, E., Almeida, R. R. de y González Cesteros, H. (2016b), "Ovoide 5 (Valle del Guadalquivir)”, Amphorae ex Hispania. Paisajes de producción y de consumo (http://amphorae. icac.cat/amphora/ovoid-5-guadalquivir-valley), 20 julio, 2016. (Consulta 30-IX-2017)

García Vargas, E., Almeida, R. R. de y González Cesteros, H. (2016c), "Ovoide 6 (Valle del Guadalquivir)”, Amphorae ex Hispania. Paisajes de producción y de consumo (http://amphorae. icac.cat/amphora/ovoid-6-guadalquivir-valley), 20 julio, 2016. (Consulta 13-X-2017)

García Vargas, E. y Bernal Casasola, D. (2008), “Ánforas de la Bética”, Cerámicas hispanorromanas: un estado de la cuestión (Bernal Casasola, D. y Ribera i Lacomba, A. Eds.), Cádiz, Universidad de Cádiz, 661-687.

García Vargas, E. y Bernal Casasola, D. (2016), "Dressel 7 (Costa de Baetica)", Amphorae ex Hispania. Paisajes de producción y de con- 
sumo (http://amphorae.icac.cat/tipol/view/7), 04 julio, 2016. (Consulta 6-VII-2017)

García Vargas, E., González Cesteros, H. y Almeida, R. R. de (no prelo), "Análisis de caso: las ánforas ovoides de la Hispania Tardorrepublicana”, Actas del Seminário Amphorae Ex Hispania (Tarragona 2012).

García Vargas, E. y López Rosendo, E. (2008), “El alfar de Rabatún (Jerez de la Frontera, Cádiz) y la producción de ánforas y cerámica común en la campiña del Guadalete en época altoimperial romana”, Spal, 17, 281-313.

García Vargas, E., Martín-Arroyo Sánchez, D. y Lagóstena Barrios, L. (2016a), "Dressel 8 (Costa de Baetica)". Amphorae ex Hispania. Paisajes de producción y de consumo (http://amphorae.icac.cat/tipol/view/8), 04 julio, 2016. (Consulta 9-VII-2017)

García Vargas, E., Martín-Arroyo Sánchez, D. y Lagóstena Barrios, L. (2016b), "Dressel 9 (Costa de Baetica)". Amphorae ex Hispania. Paisajes de producción y de consumo (http://amphorae.icac.cat/tipol/view/9), 04 julio, 2016. (Consulta 9-VII-2017)

García Vargas, E., Martín-Arroyo Sánchez, D. y Lagóstena Barrios, L. (2012c), "Dressel 10 (Costa de Baetica)". Amphorae ex Hispania. Paisajes de producción y de consumo (http://amphorae.icac.cat/tipol/view/10), 04 julio, 2016. (Consulta 10-VII-2017)

García Vargas, E., Martín-Arroyo Sánchez, D. y Lagóstena Barrios, L. (2012c), "Dressel 11 (Costa de Baetica)". Amphorae ex Hispania. Paisajes de producción y de consumo (http://amphorae.icac.cat/tipol/view/11), 04 julio, 2016. (Consulta 10-VII-2017)

García Vargas, E. y Sáez Romero, A. M. (no prelo), "Producciones hispanas: Bahía de Cádiz y costa meridional de Hispania Ulterior", A "Family Business": The Ovoid Amphorae in the Central and Western Mediterranean. Workshop Internacional (Sevilla, diciembre de 2015).

Gauthier, B. y Joncheray, J. P. (1993), "Le gisement C du Cap Gros", Cahiers d'Archéologie Subaquatique, XII, 167-183.

González Cesteros, H. (2012), “Scomber gaditano en Éfeso. Una Dressel 12 con titulus encontrada en la "Casa Aterrazada 2" de Éfeso", Dialogues d'Histoire Ancienne, 38/1, Besançon, 111-124. González Cesteros, H. (2014), Ánforas hispanas en la Germania Inferior antes de la formación de la provincia 20 a.C. - 69 d.C. Tesis doctoral, Universitat Rovira Virgili.

González Cesteros, H. y Almeida, R. R. de (2016), "Chapter 3. Amphorae from the West: Hispania (Spain and Portugal) - A. Las ánforas de aceite de oliva béticas. De las Oberaden 83 hasta las Dressel 20 en el Kops Plateau de Nimega”, Amphorae from the Kops Plateau (Nijmegen): trade and supply to the Lower-Rhineland from the Augustan period to AD 69/70 (Carreras Monfort, C. y Berg, J. van den Eds.), Oxford, Archaeopress Publishing Ltd., 47-60.

González Cesteros, H., Almeida, R. R. de y García Vargas, E. (2016), "Ovoide 1 (Valle del Guadalquivir)”, Amphorae ex Hispania. Paisajes de producción y de consumo (http://amphorae. icac.cat/amphora/ovoid-1-guadalquivir-valley), 08 julio, 2016. (Consulta 24-XI-2017)

González Cesteros, H.; Bernal Casasola, D. y García Vargas, E. (2016), "Dressel 12 (Costa Bética)", Amphorae ex Hispania. Paisajes de producción y de consumo (http://amphorae.icac.cat/ amphora/dressel-12-baetica-coast), 08 julio, 2016. (Consulta 13-VII-2017)

González Cesteros, H. y Berni Millet, P. (no prelo): Roman amphorae in Neuss. From augustan to julio-claudian contexts. OAI. Viena.

González Cesteros, H., García Vargas, E. y Almeida, R. R. de (2016), "Oberaden 83 (Valle del Guadalquivir)", Amphorae ex Hispania. Paisajes de producción y de consumo (http://amphorae. icac.cat/amphora/oberaden-83-guadalquivir-valley), 20 julio, 2016. (Consulta 29-XI-2017)

González Cesteros, H. y Tremmel, B. (2013), "Las ánforas de Oberaden”, De vino et oleo Hispaniae. Áreas de producción y procesos tecnológicos del vino y el aceite en la Hispania romana. Coloquio Internacional, Anales de Prehistoria y Arqueología 27-28, Murcia, 527542.

González-Ruibal, A.; Rodríguez Martínez, R.; Aboal Fernández, R. y Castro Hierro, V. (2007), "Comercio mediterráneo en el castro de Montealegre (Pontevedra, Galicia). Siglo II a.C. - inicios del siglo I d.C.”, Archivo Español de Arqueología, 80, 43-74.

Goudineau, C. y Brentchaloff, D, (Eds.) (2009), Le camp de la flotte d'Agrippa à Fréjus: les fouilles du quartier de Villeneuve (1979-1981), París. 
Gradim, A., Grabherr, G., Kainrath, B. y Teichner, F. (2014), "O Castelinho dos Mouros (Alcoutim) : um edifício republicano do baixo Guadiana, no período de fundação da Lusitânia romana”, La gestación de los paisajes rurales entre la Prehistoria y el período romano. Formas de asentamiento y procesos de implantación (Mayoral Herrera, V., Mataloto, R. y Roque, C. Eds.), Anejos de Archivo Español de Arqueología LXX, Mérida, Consejo Superior de Investigaciones Científicas, 45-64.

Guerra, A. (1995), Plínio-o-Velho e a Lusitânia, Colecção Arqueologia e História Antiga 1, Lisboa, Edições Colibri.

Guerra, A., Pimenta, J. y Sequeira, J. (2014), “Conjunto de Glandes Plumbeae do sítio arqueológico de Alto dos Cacos, Almeirim”, Atas do Congresso Internacional de Arqueologia Conquista e Romanização do Vale do Tejo (Vila Franca de Xira, 2013), Cira Arqueologia 3, Vila Franca de Xira, Museu Municipal de Vila Franca de Xira, 293-321.

Guerrero Ayuso, V. (1987), La colonia de Sant Jordi (Mallorca). Estudis d'Arqueologia $i$ Epigrafia, Palma de Mallorca, Publications del Centre d'Estudis Gabriel Alomar.

Helly, B., Le Bot-Helly, A. y Liou, B. (1986), "Un dépôt d'amphores Dressel 20 à inscriptions peintes découvert à Sainte-Colombe (Rhône)", Archaeonautica, 6, 121-145.

Henriques, E. (1982), Elementos para a Carta Arqueológica do Concelho de Almeirim, Texto manuscrito, 19/12/82, Processo 82/1 (242) IGESPAR.

Hesnard, A. (1998), “M. Lollius Q. f. et les amphores Lamb. 2 pompéiennes”, Recueil de Timbres sur Amphores Romaines II (1989-90 et compléments, 1987-1988) (Blanc-Bijon, V., Carre, M.-B., Hesnard, A. y Tchernia, A. Eds.), Aix-en-Provence, 307-312.

Lagóstena Barrios, L. (1996a), Alfarería romana en la Bahía de Cádiz, Cádiz.

Lagóstena Barrios, L. (1996b), "Explotación del salazón en la Bahía de Cádiz en la Antigüedad: aportación al conocimiento de su evolución a través de la producción de las ánforas Maña C”, Florentia Iliberritana, 7, 141-169.

Laubenheimer, F., Formenti, F., Liou, B., Béraud, I. y Gébara, C. (1991), "Les vides sanitaires et les amphores de la Porte d'Orée à Fréjus (Var)", Gallia, 48, 229-265.
Lemaître, S., Desbat, A. y Maza, G. (1998), "Les amphores du site du "sanctuaire de Cybèle" à Lyon. Étude preliminaire”, SFECAG Actes du Congrés d'Istres, 45-59.

Lillo Carpio, P. (1986), "Habitats singulares en la Edad Antigua. La Cueva de Las Peñas Blancas en las Lomas de la Carrasca (Cartagena)", Anales de Prehistoria y Arqueología, 2, 121-129.

Liou, B. (2001), "Las ánforas béticas en el mar. Les épaves en Méditerranée à cargaison d'amphores de Bétique", Congreso Internacional Ex Baetica Amphorae. Conservas, Aceite y Vino de la Bética en el Império Romano (Écija-Sevilla 1998), Vol. III, Écija, Editorial Sol, 10611111.

Loeschcke, S. (1909), Ausgrabungen bei Haltern. Die Keramische Funde, Mitteilungen der Altertums-Kommission für Westfalen 5, Münster. López Rosendo, E. (2008), "El alfar romano altoimperial del Jardín de Cano (El Puerto de Santa María, Cádiz, España), en el contexto económico de "Gades", Revista de Historia de El Puerto, 41, 39-74.

López Rosendo, E. (2010), "Los talleres alfareros del Jardín de Cano (El Puerto de Santa María, Cádiz). La producción anfórica de Gades en torno al cambio de era”, Rei Cretariae Romanae Fautorum Acta 41, Bonn, 411-419.

Madeira, M. S. P. S. (1988), "Subsídios para o estudo do material anfórico dos "Castella" da zona de Castro Verde", Actas do $1^{\circ}$ Encontro de Arqueologia da região de Beja (Beja, 1986), Arquivo de Beja $2^{a}$ série - 3, Beja, Câmara $\mathrm{Mu}-$ nicipal de Beja, 121-138.

Manacorda, D. (1994), "Produzione agricola, produzione cerámica e proprietà della terra nella Calabria romana tra Repubblica e Impero”, Epigrafia della Produzione e dela Distribuzione, École Française de Rome 193, Rome, 3-59.

Manacorda, D. y Pallecchi, S. (2012), Le fornaci romane di Giancola (Brindisi), Bari.

Mantas, V. (1993), “As fundações coloniais no território português nos finais da República e os inícios do Império", Actas do II Congresso Peninsular de História Antiga (Coimbra 1990), Coimbra, Universidade de Coimbra, 465-500.

Mantas, V. (2002), "A Rede Viária de Scallabis", De Scallabis a Santarém. Catálogo da exposiçao, Lisboa, Museu Nacional de Arqueologia, 107-112.

Márquez Villora, J.C. y Molina Vidal, J. (2001), El 
Comércio en el Territorio de Ilici. Epigrafía, importación de alimentos y relación con los mercados mediterráneos. Alicante, Publicaciones de la Universidad de Alicant.

Martín Menéndez, A. (2008), “Àmfores tarraconenses i bétiques em els dereclites de mitjan segle I a.C. a la costa catalana", SFECAG, Actes du congres de l'Escala-Empuries. Les productions ceramiques en Hispanie Tarraconaise (IIe siècle avant J.-C.-VIIe siècle après J.-C.), 103-127.

Martin-Kilcher, S. (1987), Die römischen Amphoren aus Augst und Kaiseraugst I. Augst.

Martin-Kilcher, S. (1993), "Amphoren der späten Republik und frühen Kaiserzet in Karthago”, Mitteilungen des Deutsches Archäologischen Instituts, Römische Abteilung, 100, 269-320.

Martin-Kilcher, S. (1994), Die römischen Amphoren aus Augst und Kaiseraugst 2: Die Amphoren für Wein, Fischsauce, Südfrüchte (Gruppen 2-24) und Gesamtauswertung, Bern.

Martin-Kilcher, S. (1999), "Amphoren”, Römische Keramik in der Schweiz (Schucany, C.; Martin-Kilcher, S., Berger, L. y Paunier, D. (Hrsg.), Antiqua 31, Basel, Verl.Schweizerische Gesellschaft für Ur- und Frühgeschichte.

Martin-Kilcher, S. (2001), "Amphores à sauces de poisson du sud de la Péninsule Ibérique dans les provinces septentrionales”, Actas del Congreso Internacional Ex Baetica Amphorae. Conservas, Aceite y Vino de la Bética en el Império Romano (Écija-Sevilla 1998) Vol. III, Écija, Editorial Sol, 759-787.

Martin-Kilcher, S. (2003), "Fish-sauces amphorae from the Iberian Peninsula: The forms and observations on trade with the noth-west provinces”, Journal of Roman Potteyr Studies, 10, 69-84.

Martin-Kilcher, S.; Deschler-Erb, E.; Roth-Zehner, M.; Spichtig, N. y Thierrin-Michael, G. (2013), "Les importations en amphores dans la civitas Rauracorum IIe/Ier siècle av. J.-C. - Ier siècle apr. J.-C. Bâleusine à gaz, Sierentz, Sausheim, Bâle-colline de la cathédrale, Augst”. Itinéraires des vins romains en Gaule, IIIe - Ier siècles avant J.-C. Confrontation de facies (Lattes 2007) (Olmer, F. Ed.), Lattes, 377-400.

Mas García, J. (1985), "Excavaciones en el yacimiento submarino de San Ferreol", VI Congreso Internacional de Arqueología Submarina
(Cartagena, 1982), Cartagena, 189-224.

Mataloto, R. (2008), "O Castelo dos Mouros (Graça do Divor, Évora): a arquitectura 'ciclópica' romana e a romanização dos campos de Liberalitas Iulia Ebora", Revista Portuguesa de Arqueologia, 9.2, 299-316.

Mataloto, R., Williams, J. y Roque, C. (2016), "Amphorae at the Origins of Lusitania: Transport Pottery from Western Hispania Ulterior in Alto Alentejo", Lusitanian Amphorae: Production and Distribution (Pinto, I.V., Almeida, R.R de y Martin, A. Eds.), Roman and Late Antique Mediterranean Pottery 10, Oxford, 139-151.

Mateo Corredor, D. (2016), Comercio anfórico y relaciones mercantiles en Hispania Ulterior (ss. II a.C.-II d.C.), Col.Leció Instrumenta 52, Barcelona, Universitat de Barcelona.

Mateo Corredor, D. y Mayorga Mayorga, J. F. (2017), "Comercio anfórico tardorrepublicano en Malaca: las importaciones de calle Beatas-esquina Ramón Franquelo (Málaga, España)”, Saguntum, 49, 103-122.

Mauné, S., García Vargas, E., Bourgeon, O., Corbeel, S., Carrato, C., García-Dils, S., Bigot, F. y Vázquez Paz, J. (2014), "L'atelier d'amphores à huile dr. 20 de Las Delicias à Écija (Prov. de Séville, Espagne)”, SFECAG. Actes du Congrés (Chartres 29 Mai - 1 Juin 2014), 419-444.

Mayet, F., Schmitt, A. y Silva, C. T. (1996), Les amphores du Sado (Portugal). Prospection des fours et analyse du matériel, Paris, E. de Boccard.

Mayet, F. y Silva, C. T. (1998), L'Atelier d'amphores de Pinheiro (Portugal), Paris, E. de Boccard.

Mayet, F. y Silva, C. T. (2002), L'Atelier d'amphores de Abul (Portugal), Paris, E. de Boccard.

Mayet, F. y Silva, C. T. (2006), "Roman Amphora Production in the Lower Sado Region", Lusitanian Amphorae: Production and Distribution (Pinto, I.V., Almeida, R.R de y Martin, A. Eds.), Roman and Late Antique Mediterranean Pottery 10, Oxford, 59-71.

Molina Vidal, J. (1995), "Las ánforas Lomba do Canho 67. Aportaciones al estudio de un nuevo tipo: difusión y valoración económica”, Actas del XXII Congreso Nacional de Arqueología, Vigo, 419-424.

Molina Vidal, J. (1997), La dinámica comercial romana entre Italia e Hispania Citerior, Ali- 
cant, Instituto de Cultura Juan Gil- Albert.

Molina Vidal, J. (2001), "Las primeras exportaciones béticas en el Mediterráneo occidental", $A c$ tas del Congreso Internacional Ex Baetica Amphorae. Conservas, Aceite y Vino de la Bética en el Império Romano (Écija-Sevilla 1998), Vol. II, Écija, Editorial Sol, 637-645.

Molina Vidal, J. (2013), "Commerce et marchés de vin italique dans le sud de l'Hispanie Citérieure (IIIe-Ier siècles av. notre ère)", Itinéraires des vins romains en Gaule, IIIe - Ier siècles avant J.-C. Confrontation de facies (Lattes 2007) (Olmer, F. Ed.), Lattes, 195-212.

Montero Fernández, A., Montero Fernández, R., Sáez Romero, A. y Díaz Rodríguez. J. J. (2004), "Innovaciones, transformaciones y pervivencias. Evolución de la alfarería gadirita durante los siglos III-II a.n.e.", Figlinae Baeticae. Talleres Alfareros y Producciones Cerámicas en la Bética Romana (ss. II a.C. - II d.C.) (Cádiz, 2003) (Bernal Casasola, D. y Lagóstena Barrios, L. Eds.), B.A.R. International Series 1266, Oxford, 413-426.

Morais, R. (1998), As ânforas da Zona das Carvalheiras. Contribuição para o estudo das ânforas romanas de Bracara Augusta. Braga, Instituto de Ciências Sociais da Universidade do Minho.

Morais, R. (2001), “As ânforas béticas em Bracara Augusta”. Actas del Congreso Internacional Ex Baetica Amphorae. Conservas, Aceite y Vino de la Bética en el Império Romano (Écija-Sevilla 1998), Vol. II, Écija, Editorial Sol, 683-701.

Morais, R. (2004a), “Tipologia de les Àmfores Haltern 70 i Produccions Similars, Problemàtiques i Noves Perspectives sobre les Àmfores Ovoides Tardo-Republicanes. Les Àmfores Ovoides de Producció Lusitana”, Culip VIII $i$ les Àmfores, Haltern 70, Monografies del Casc 5, Girona, Museu d'Arqueologia de Catalunya / Centre d'Arqueologia Subaquàtica de Catalunya, 36-41.

Morais, R. (2004b), "Bracara Augusta: um pequeno Testaccio de ânforas Haltern 70. Considerações e problemáticas de estudo", Figlinae Baeticae. Talleres Alfareros y Producciones Cerámicas en la Bética Romana (ss. II a.C. - II d.C.) (Cádiz, 2003) (Bernal Casasola, D. y Lagóstena Barrios, L. Eds.), B.A.R. International Series 1266, Oxford, 545-566.

Morais, R. (2010), “Ânforas”, Castelo da Lousa.
Intervenções Arqueológicas de 1997 a 2002 (Alarcão, J., Carvalho, P. C. y Gonçalves, A. Eds.), Stvdia Lvsitana 5, Mérida, Museo Nacional de Arte Romano / Edia, 181-218.

Morais, R. y Carreras Monfort, C. (2004), “Geografia del Consum de les Haltern 70, Zona Atlàntica”, Culip VIII $i$ les Àmfores, Haltern 70, Monografies del Casc 5, Girona, Museu d'Arqueologia de Catalunya / Centre d'Arqueologia Subaquàtica de Catalunya, 93-111.

Morais, R. y Fabião, C. (2007), "Novas produções de fabrico lusitano: problemáticas e importância económica”, Actas del Congreso International Cetariae 2005. Salsas y salazones de pescado en occidente durante la antiguidad (Cádis, 7-9 de noviembre del 2005), B.A.R International Series 1686, Oxford, 127-133.

Morais, R. y Filipe, V. (2016), "Ovoide Lusitana (Lusitania Occidental)", Amphorae ex Hispania. Paisajes de producción y de consumo (http://amphorae.icac.cat/amphora/ovoid-lusitan-western-lusitania), 20 julio, 2016 (Consulta 5-X-2017).

Morel, J. P. (1981), Céramiques Campanienne. Les Formes. 2 Vols, Ecole Française de Rome, Rome.

Morillo, A. (2007), El ejército romano en Hispania. Guía Arqueológica, Léon, Universidad de León.

Mota, N., Pimenta, J. y Silva, R. B. (2014), “Acerca da ocupação romana republicana de Olisipo: os dados da intervenção na Rua do Recolhimento n. ${ }^{\circ}$ s 68-70”, Atas do Congresso Internacional de Arqueologia Conquista e Romanização do Vale do Tejo (Vila Franca de Xira, 2013), Cira Arqueologia 3, Vila Franca de Xira, Museu Municipal de Vila Franca de Xira, 149-177.

Oosterbeek, L. y Correia, S. (1984), Informação arqueológica (1981), 4, Lisboa, Departamento de Arqueologia do IPPC.

Palazzo, P. (1988), “Aspetti tipologici della produzione di anfore brindisine”, La Puglia in età republicana, Galatina, 109-117.

Palazzo, P. (1989), "Le anfore di Apani (Brindisi)", Amphores Romaines et Histoire Économique : Dix Ans de Recherches (Actes du Colloque de Siena, 1986), Collection de L'École Française de Rome 114, Roma, 548-553.

Palazzo, P. (2013), Le anfore di Apani (Brindisi), Roma.

Panella, C. (2010), "Roma, il suburbio e l'Italia in 
età medio- e tardo-repubblicana: cultura materiale, territori, economie". Facta. A journal of roman material culture studies, 4, 11-123.

Parreira, J. C. (2009), As ânforas romanas de Mesas do Castelinho. Tese de Mestrado, Lisboa, Faculdade de Letras da Universidad de Lisboa. repositorio.ul.pt/bitstream/10451/446/1/21415_ulflo71253_ tm.pdf

Pascual Berlanga, G. y Ribera i Lacomba, A. (2001), "El consumo de productos béticos en Valentia y su entorno: la continuidad de una larga tradición”, Actas del Congreso Internacional Ex Baetica Amphorae. Conservas, Aceite y Vino de la Bética en el Império Romano (Écija-Sevilla 1998), Vol. II, Écija, Editorial Sol, 565576.

Peacock, D. P. S. y Williams, D. F. (1986), Amphorae and the roman economy. An Introductory Guide, London, Longman.

Peña Santos, A. de la (1986), Yacimiento galaicorromano de Santa Trega (A Guarda, Pontevedra). Campaña de 1983, Arqueoloxía / Memorias 5, Santiago de Compostela.

Perdigones Moreno, L. y Muñoz Vicente, A. (1988), "Excavaciones arqueológicas de urgencia en los hornos púnicos de Torre Alta, San Fernando, Cádiz”, Anuario Arqueológico de Andalucía 1986, 106-112.

Pesavento Mattioli, S. (2014), "Le produzioni di anfore vinarie nei territori adriatici: questioni di método", Officine per la produzione di ceramica e vetro in época romana. Produzione e commercio nella regione adriatica, Atti del II colloquio archeologico internazionale, Crikvenica (Croazia, 28-29 ottobre 2011)(Lipovac Vrklian, G., Šiljeg, B., Ozanić Roguljić, I. y Konestra, A., eds.), Crikvenica, 191-198.

Pimenta, J. (2005), As ânforas Romanas do Castelo de São Jorge (Lisboa), Trabalhos de Arqueologia 41, Lisboa, Instituto Português de Arqueologia.

Pimenta, J. (Coord.) (2013), Monte dos Castelinhos (Castanheira do Ribatejo, Vila Franca de Xira) e a conquista romana no Vale do Tejo. Catálogo da Exposição, Vila Franca de Xira, Museu Nacional de Arqueologia / Museu Municipal de Vila Franca de Xira.

Pimenta, J. (Coord.) (2015), O sítio arqueológico de Monte dos Castelinhos. Em busca de Ierabriga. Catálogo da Exposição, Vila Franca de
Xira, Museu Municipal de Vila Franca de Xira.

Pimenta, J. (2017), "Em torno dos mais antigos modelos de ânfora de produção lusitana. Os dados do monte dos castelinhos - Vila Franca de Xira”, Actas Seminário Internacional e Ateliê de Arqueologia Experimental. A Olaria Romana (Seixal 17-20 de Fevereiro de 2010) (Fabião, C., Raposo, J., Guerra, A. y Silva, F. Eds.), Lisboa, UNIARQ - Centro de Arqueologia da Universidade de Lisboa / Câmara Municipal do Seixal, 195-205.

Pimenta, J. y Arruda, A. M. (2014), "Novos dados para o estudo dos Chões de Alpompé - Santarém”. Estudos Arqueológicos de Oeiras, 21, 375-392.

Pimenta, J., Gapar, A., Gomes, A., Mota, N. y Miranda, P. (2014), "O estabelecimento romano republicano de Olisipo: estrutura e contextos do Beco do Forno do Castelo, Lote 40 (n.16-20), Lisboa”, Atas do Congresso Internacional de Arqueologia Conquista e Romanização do Vale do Tejo (Vila Franca de Xira, 2013), Cira Arqueologia 3, Vila Franca de Xira, Museu Municipal de Vila Franca de Xira, 122-148.

Pimenta, J., Ferreira, M. y Cabrita, C. (2016), “The Roman Kilns at Estrada da Parvoíce, Alcáçer do Sal (Portugal)", Lusitanian Amphorae: Production and Distribution (Pinto, I. V., Almeida, R. R de y Martin, A. Eds.), Roman and Late Antique Mediterranean Pottery 10, Oxford, 7379.

Pimenta, J., Henriques, E. y Mendes, H. (2012), O Acampamento romano de Alto dos Cacos, Almeirim, Almeirim, Associação de Defesa do património Histórico e Cultural do Concelho de Almeirim.

Pimenta, J. y Mendes, H. (2014), "Monte dos Castelinhos - Vila Franca de Xira. Um sitio singular para o estudo da romanizaçāo do vale do Tejo", La gestación de los paisajes rurales entre la Prehistoria y el periodo romano. Formas de asentamiento y procesos de implantación (Mayoral Herrera, V., Mataloto, R. y Roque, C. Eds.), Anejos de Archivo Español de Arqueología LXX, Mérida, Consejo Superior de Investigaciones Científicas, 125-142.

Pimenta, J., Mendes, H. y Henriques, E. (2014), “O Acampamento militar romano do Alto dos $\mathrm{Ca}$ cos, Almeirim", Atas do Congresso Internacional de Arqueologia Conquista e Romanização do Vale do Tejo (Vila Franca de Xira, 
2013), Cira Arqueologia 3, Vila Franca de Xira, Museu Municipal de Vila Franca de Xira, 256292.

Pimenta, J., Mendes, H. y Norton, J. (2008), “O Povoado Tardo-Republicano do Monte dos Castelinhos, Vila Franca De Xira”, Al-Madan, II Série $n^{\circ} 16,26-37$.

Pimenta, J., Sepúlveda, E., Faria, J. C. y Ferreira, M. (2006), "Cerâmicas romanas do lado ocidental do castelo de Alcácer do Sal, 4: ânforas de importação e de produção lusitana”, Revista Portuguesa de Arqueologia, 9.2, 299-316.

Pimenta, J., Sepúlveda, E. y Ferreira, M. (2006), "Acerca da dinâmica económica do porto de Urbs Imperatoria Salacia: o estudo das ânforas”, Cira Arqueologia, 4, Vila Franca de Xira, Museu Municipal de Vila Franca de Xira, 151-170.

Pinto, I.V., Almeida, R.R de y Martin, A. (Eds.) (2016), Lusitanian Amphorae: Production and Distribution, Roman and Late Antique Mediterranean Pottery 10, Oxford, Archaepress.

Pomey, P., Long, L., L'Hour, M., Richez, F. y Bernard, H. (1989), "Recherches sous-marines", Gallia - Informations, 1 (1987-88), 1-78.

Quaresma, J. C. (2005), “Ânforas romanas provenientes da pesca de arrasto no Tejo, depositadas no Museu Municipal de Vila Franca de Xira”, Revista Portuguesa de Arqueologia, 8.2, 403428.

Quaresma, J. C. y Calais, C. (2005), "S. Pedro (Coruche): novos dados para o processo de romanização do Vale do Sorraia na época augustana e júlio-cláudia”, Revista Portuguesa de Arqueologia, 8.2, 429-447.

Quinteira, A. J. F. (1996), Scallabis, análise contextual e perspectivas de estudo. Tese de Mestrado. Braga, Universidade do Minho.

Quinteira, A. J. F. (1998), "Estação arqueológica da Azeitada (Almeirim)”, Conimbriga, 37, 151183.

Ramon Torres, J. (1995), Las ánforas fenicio-púnicas del Mediterráneo central y occidental, Col.lecció Instrumenta 2, Barcelona, Publications de la Universidad de Barcelona.

Remesal Rodríguez, J. (1983), “Transformaciones en la exportación del aceite bético a mediados del siglo III d.C.", Producción y comercio del aceite en la Antigüedad. Segundo Congreso Internacional (Sevilla, 1982), Madrid, Universidad Complutense, 115-131.

Remesal Rodríguez, J. (1986), La annona milita- ris y la exportación de aceite bético a Germania. Con un corpus de sellos en ánforas Dressel 20 hallados en Nimega, Colonia, Mainz, Saalburg, Zugmantel y Nida-heddernheim, Madrid, Universidad Complutense.

Sáez Fernández, P., Tinoco Muñoz, J., García Vargas, E. y García-Dils de La Vega, S. (2001), "Excavación arqueológica de urgencia en el alfar romano de Las Delicias (Écija, Sevilla), 1997”, Anuario Arqueológico de Andalucía 1997, vol. III, 562-575.

Sáez Romero, A. M. (2008), La producción cerámica en Gadir en época tardopúnica (siglos $-I I I /-I)$, B.A.R International Series S1812, Oxford.

Sáez Romero, A. M., Bernal Casasola, D., García Vargas, E. y Díaz Rodríguez, J. J. (2016), "Ramon T-7433 (Costa Bética)”, Amphorae ex Hispania. Paisajes de producción y de consumo (http://amphorae.icac.cat/amphora/ramon-t-7433-baetica-coast), 10 julio, 2016. (Consulta 21-VII-2017)

Schönberger, H y Simons, H-G. (1976), Das augusteische Römerlagern Rödgen. Die Funde aus dem Frühkaiserzeitlichen Lagern Rödgen, Friedberg und Bad Nauheim, Limesforschungen XIV, Berlim.

Silva, A. (2008), Vivre au-dela du fl euve de l'oubli. Portrait de la communauté villageoise du Castro do Vieito (estuaire do Rio Lima, NO du Portugal), au moment de l'intégration du NO de la péninsule ibérique dans l'orbis romanum, Tese de Doutoramento em Arqueologia, Coimbra, Faculdade de Letras da Universidade de Coimbra.

Silva, C. T. (1996), "Produção de ânforas na área urbana de Setúbal: a oficina romana do Largo da Misericórdia”, Ocupação romana dos estuários do Tejo e do Sado. Actas das Primeiras Jornadas sobre Romanização dos Estuários do Tejo e do Sado (Filipe, G. y Raposo, J. M. C. Eds.), Seixal, Câmara Municipal / Lisboa, Dom Quixote, 43-54.

Silva, R. B. (2015), "O contexto alto-imperial da Rua dos Remédios (Alfama, Santa Maria Maior, Lisboa): vidros, cerâmicas e análise contextual”, Contextos Estratigráficos na Lusitânia (do Alto Império à Antiguidade Tardia), Monografias AAP 1, Lisboa, Associação dos Arqueólogos Portugueses, 41-67.

Silva, R. B. (no prelo), "O fácies cerâmico em Olisi- 
po (Lisboa): o período Julio-Claudio, Actas del Symposio Internacional "Facies y contextos Cerámicos Alto-Imperiales en el Sul de la Península Ibérica (Granada, 2013), Granada, Universidad de Granada.

Silva, R. B., Pimenta, J. y Mendes, H. (2013), “A Terra Sigillata do acampamento militar romano de Alto dos Cacos (Almeirim)", Arqueologia em Portugal. 150 anos, Actas do I Congresso da Associação dos Arqueólogos Portugueses (Lisboa, Novembro 2013) (Arnaud, J. M., Martins, A. y Neves, C. Eds), Lisboa, 775-783.

Soares, J. y Silva, C. T. (1973), "Ocupação do período Proto-Romano do Pedrão (Setúbal)”, Actas das II Jornadas Arqueológicas da Associação dos Arqueólogos Portugueses, Lisboa, Associação dos Arqueólogos Portugueses, 245-305.

Soeiro, T. (1984), Monte Mózinho: apontamentos sobre a ocupação entre Sousa e Tâmega em época romana. Penafiel-Boletim Municipal de Cultura $3^{\text {a }}$ Série $\mathrm{n}^{\mathrm{0}} 1$. Penafiel.

Sousa, E., Pimenta, J., Mendes, H. y Arruda, A. M. (2016-2017), "A Ocupação Proto-Histórica do Alto dos Cacos (Almeirim, Portugal)”, Cira Arqueologia, 5, 9-32.

Tchernia, A. (1986), Le Vin de l'Italie Romaine. Essai d'Histoire Economique d'Aprés les Amphores, Paris, École Française de Rome.

Tchernia, A. (1990), "Contre les épaves", Gaule Interne et Gaule Méditerranéenne aux IIe et Ier Siècles avant J.-C. Confrontations et Chronologies (Duval, A., Morel, J.-P. y Roman, Y. Eds.), Revue Archéologique Narbonnaise Sup 21, 291-301.

Tchernia, A., Pomey, P. y Hesnard, A. (1978), "Les amphores”, L'épave romaine de La Madrague de Giens. Gallia Sup. XXXI, Paris, 33-50.

Viegas, C. (2003), Terra sigillata da Alcáçova de Santarém. Economia, comércio e cerámica, Trabalhos de Arqueologia 26, Lisboa.

Viegas, C. (2011), A ocupacão romana do Algarve. Estudo do povoamento e economia do Algarve central e oriental no período romano, Estudos \& Memórias 3, Lisboa, Centro de Arquologia da Universidade de Lisboa / FCT.

Viegas, C. (2016), "Almagro 51C (Lusitania Meridional)", Amphorae ex Hispania. Paisajes de producción y de consumo (http://amphorae. icac.cat/amphora/almagro-51c-western-lusitania), 08 julio, 2016 (Consulta 13-I-2018).

Viegas, C. y Arruda A. M. (2013), “Ânforas roma- nas de época imperial de Monte Molião(Lagos): as Dressel 20”, Arqueologia em Portugal. 150 anos, Actas do I Congresso da Associação dos Arqueólogos Portugueses (Lisboa, Novembro 2013) (Arnaud, J. M., Martins, A. y Neves, C. Eds), Lisboa, 727-735.

Viegas, C., Raposo, J. M. C. y Pinto, I. V. (2016): “Almagro 51C (Lusitania Occidental)”, Amphorae ex Hispania. Paisajes de producción y de consumo (http://amphorae.icac.cat/amphora/ almagro-51c-western-lusitania), 20 julio, 2016 (Consulta 13-I-2018).

Zechini, M. (1982), Relitti romani dell'Isola d'El$b a$, Lucca.

Zévi, F. (1966), “Apunti sulle anfore romane I. La tavola tipologica de Dressel”, Archaeologia Classica, 18, 208-247. 